USAF HISTORICAL STUDIES: NO. 155

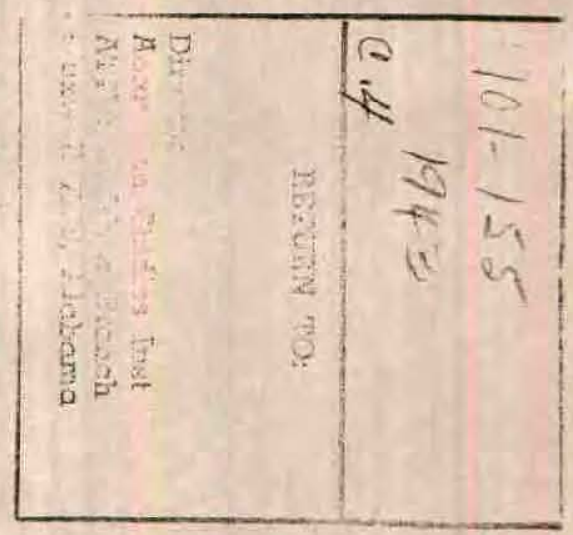

\title{
THE GERMAN AIR FORCE VERSUS RUSSIA, 1943
}

\author{
by
}

Generalleutnant Hermann Plocher

SCANNED BY ACD

2005
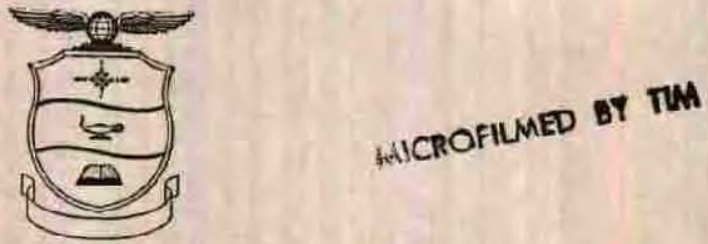

USAF HISTORICAL DIVISION

AEROSPACE STUDIES INSTITUTE

$$
\text { AIR UNIVERSITY }
$$

JUNE 1967

10 NOV 1969

$$
\text { DR69-4/27 }
$$

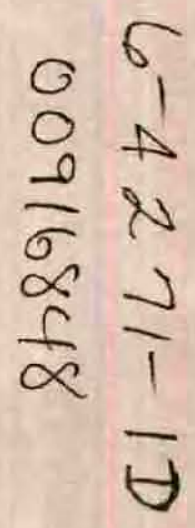




\section{Report Documentation Page}

Form Approved

OMB No. 0704-0188

Public reporting burden for the collection of information is estimated to average 1 hour per response, including the time for reviewing instructions, searching existing data sources, gathering and maintaining the data needed, and completing and reviewing the collection of information. Send comments regarding this burden estimate or any other aspect of this collection of information,

including suggestions for reducing this burden, to Washington Headquarters Services, Directorate for Information Operations and Reports, 1215 Jefferson Davis Highway, Suite 1204, Arlington

VA 22202-4302. Respondents should be aware that notwithstanding any other provision of law, no person shall be subject to a penalty for failing to comply with a collection of information if it

does not display a currently valid OMB control number.

\begin{tabular}{|c|c|c|}
\hline $\begin{array}{l}\text { 1. REPORT DATE } \\
\text { JUN } \mathbf{1 9 6 7}\end{array}$ & 2. REPORT TYPE & $\begin{array}{l}\text { 3. DATES COVERED } \\
\mathbf{0 0 - 0 0 - 1 9 6 7} \text { to 00-00-1967 }\end{array}$ \\
\hline \multirow{3}{*}{\multicolumn{2}{|c|}{ The German Air Force Versus Russia, 1943}} & 5a. CONTRACT NUMBER \\
\hline & & 5b. GRANT NUMBER \\
\hline & & 5c. PROGRAM ELEMENT NUMBER \\
\hline \multirow{3}{*}{\multicolumn{2}{|c|}{ 6. AUTHOR(S) }} & 5d. PROJECT NUMBER \\
\hline & & 5e. TASK NUMBER \\
\hline & & 5f. WORK UNIT NUMBER \\
\hline \multicolumn{2}{|c|}{$\begin{array}{l}\text { 7. PERFORMING ORGANIZATION NAME(S) AND ADDRESS(ES) } \\
\text { Air Univeristy,Aerospace Studies Institute,USAF Historical } \\
\text { Division,Maxwell AFB,AL,36112 }\end{array}$} & $\begin{array}{l}\text { 8. PERFORMING ORGANIZATION } \\
\text { REPORT NUMBER }\end{array}$ \\
\hline \multirow{2}{*}{\multicolumn{2}{|c|}{ 9. SPONSORING/MONITORING AGENCY NAME(S) AND ADDRESS(ES) }} & 10. SPONSOR/MONITOR'S ACRONYM(S) \\
\hline & & $\begin{array}{l}\text { 11. SPONSOR/MONITOR'S REPORT } \\
\text { NUMBER(S) }\end{array}$ \\
\hline
\end{tabular}

12. DISTRIBUTION/AVAILABILITY STATEMENT

Approved for public release; distribution unlimited

13. SUPPLEMENTARY NOTES

14. ABSTRACT

15. SUBJECT TERMS

16. SECURITY CLASSIFICATION OF:

\begin{tabular}{c|c|c|c|}
$\begin{array}{c}\text { a. REPORT } \\
\text { unclassified }\end{array}$ & $\begin{array}{c}\text { b. ABSTRACT } \\
\text { unclassified }\end{array}$ & $\begin{array}{c}\text { c. THIS PAGE } \\
\text { unclassified }\end{array}$ & $\begin{array}{c}\text { Same as } \\
\text { Report (SAR) }\end{array}$
\end{tabular}

\begin{tabular}{c|l}
$\begin{array}{c}\text { 18. NUMBER } \\
\text { OF PAGES } \\
\mathbf{1 9 0}\end{array}$ & 19a. NAME OF \\
& RESPONSIBLE PERSON \\
&
\end{tabular}




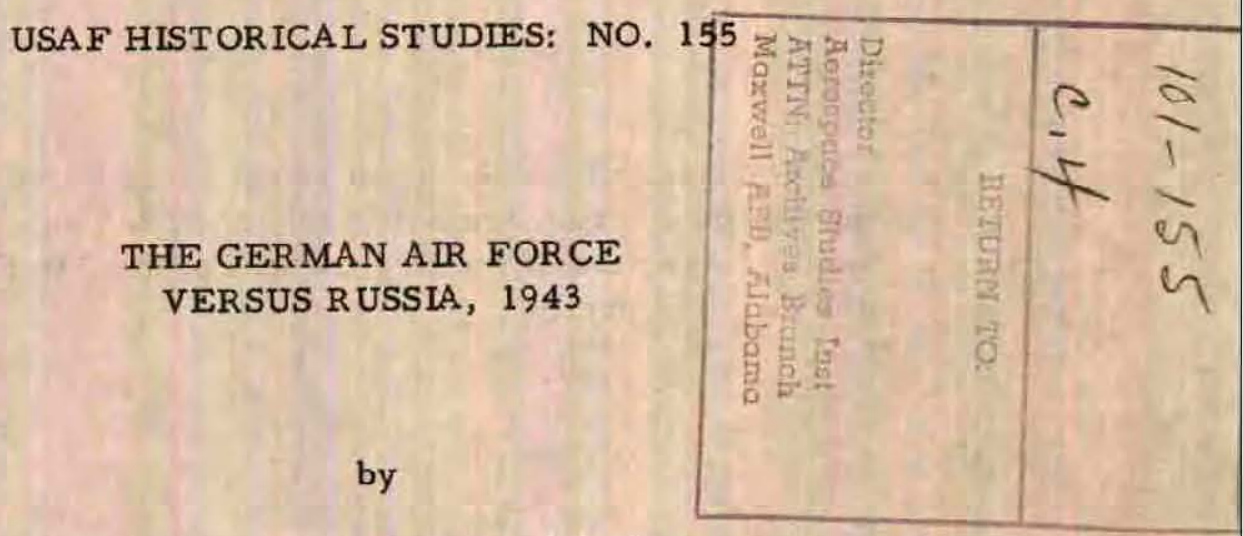

Generalleutnant Hermann Plocher

Edited by Mr. Harry R. Fletcher

USAF Historical Division

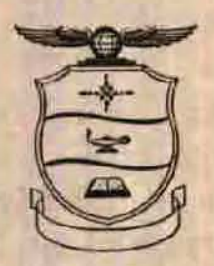

USAF HISTORICAL DIVISION

Aerospace Studies Institute

Air University

June 1967 
Personal views or opinions expressed or implied in this publication are not to be construed as carrying official sanction of the Department of the Air Force or the Air University.

This publication has been reviewed and approved by competent personnel of the preparing command in accordance with current directives on doctrine, policy, essentiality, propriety, and quality. 
Intermediary thou art between yesterday and tomorrow; What is past thou bearest into the future!

Thus thou preservest the fleeting today in life and deed.

\author{
Karl Knoblauch \\ Member of the 4 th (Strategic) \\ Flight, 14th (Muenchhausen) \\ Reconnaissance Squadron, \\ Sixth Air Fleet
}

He who would make wise use of history must recognize in the new circumstances the old kernel, and must not, through engrossment in the old elements overlook the new contexts.

Grillparzer

Historical and Political Studies 


\section{FOREWORD}

The German Air Force versus Russia, 1943, written by Generalleutnant Hermann Plocher, and revised and edited by Mr. Harry Fletcher, is one of a series of historical studies written for the United States Air Force Historical Division by men who had been key officers in the German Air Force during World War II.

The overall purpose of the series is twofold: 1) To provide the United States Air Force with a comprehensive and, insofar as possible, authoritative history of a major air force which suffered defeat in World War II, a history prepared by many of the principal and responsible leaders of that air force; 2) to provide a firsthand account of that air force's unique combat in a major war, especially its fight against the forces of the Soviet Union. This series of studies therefore covers in large part virtually all phases of the Luftwaffe's operations and organization, from its camouflaged origin in the Reichswehr, during the period of secret German rearmament following World War I, through its participation in the Spanish Civil War and its massive operations and final defeat in World War II, with particular attention to the air war on the Eastern Front.

The German Air Force Historical Project (referred to hereinafter by its shorter and current title, "The GAF Monograph Project") has generated this and other especially prepared volumes which comprise, in one form or another, a total of more than 40 separate studies. The project, which was conceived and developed by the USAF Historical Division, was, upon recommendation of Headquarters Air University late in 1952, approved and funded by Headquarters. USAF in early 1953. General supervision was assigned to the USAF Historical Division by Headquarters USAF, which continued principal funding of the project through 30 June 1958. Within the Historical Division, Dr. Albert F. Simpson and Mr. Joseph W. Angell, Jr., respectively Chief and Assistant Chief of the Division, exercised overall supervision of the project. The first steps towards its initiation were taken in the fall of 1952 following a staff visit by Mr. Angell to the Historical Division, Headquarters United States Army, Europe, at Karlsruhe, Germany, where the Army was conducting a somewhat similar historical project covering matters and operations almost wholly of interest to that service. Whereas the Army's project had produced or was producing a multiplicity of studies of varying length and significance (more than 2, 000 have been prepared to date by the Army project), it was early decided that the Air 
Force should request a radically smaller number (around 40) which should be very carefully planned initially and rather closely integrated. Thirteen narrative histories of GAF combat operations, by theater areas, and 27 monographic studies dealing with areas of particular interest to the United States Air Force were recommended to, and approved by, Headquarters USAF in the initial project proposal of late 1952. (A list of histories and studies appears at the end of this volume.)

By early 1953 the actual work of preparing the studies was begun. Col. Wendell A. Hammer, USAF, was assigned as Project Officer, with duty station at the USAREUR Historical Division in Karlsruhe, General der Flieger a. D. Paul Deichmann was appointed and served continuously as Control Officer for the research and writing phases of the project; he also had duty station at the USAREUR Historical Division. Generalleutnant a. D. Hermann Plocher served as Assistant Control Officer until his recall to duty with the new German Air Force in the spring of 1957. These two widely experienced and high-ranking officers of the former Luftwaffe secured as principal authors, or "topic leaders, "former officers of the Luftwaffe, each of whom, by virtue of his experience in World War II, was especially qualified to write on one of the topics approved for study. These "topic leaders" were, in turn, assisted by "home workers"--for the most part former general and field-grade officers with either specialized operational or technical experience. The contributions of each of these "home workers, "then, form the basic material of most of these studies. In writing his narrative the "topic leader" has put these contributions into their proper perspective.

These studies find their principal authority in the personal knowledge and experience of their authors. In preparing the studies, however, the authors have not depended on their memories alone, for their personal knowledge has been augmented by a collection of Luftwaffe documents which has come to be known as the Kaxlsruhe Document Collection and which is now housed in the Archives Branch of the USAF Historical Division. This collection consists of directives, situation reports, war diaries, personal diaries, strength reports, minutes of meetings, aerial photographs, and various other materials derived, chiefly, from three sources: the Captured German Documents Section of The Adjutant General in Alexandria, Virginia; the Air Ministry in London; and private German collections made available to the project by its participating authors and contributors. In addition, the collection includes the contributions of the "home workers." The authors have also made use of such materials as the records of the Nuremberg Trials, the manuscripts prepared by the Foreign Military Studies Branch of the USAREUR Historical Division, the official military histories of the United States 
and the United Kingdom, and the wealth of literature concerning World War II, both in German and English, which has appeared in book form or in military journals since 1945 .

With the completion of the research and writing phases in 1958 , the operations at Karlsruhe were closed out. At that time the project was moved to the Air University, Maxwell Air Force Base, Alabama, where the process of editing and publishing the studies was begun by the USAF Historical Division.

Basic revising and editing of the monographs has been handled by Mr. Edwin P. Kennedy (1958-61), Dr. Littleton B. Atkinson (1961-62), Mr. Gerard E. Hasselwander (1962-63), and the present Editor, Mr. Harry R. Fletcher. Final review and editing has been the responsibility of Dr. Albert F. Simpson, Chief, USAF Historical Division, with the assistance of Dr. Maurer Maurer, Chief of the Division's Historical Studies Branch.

The complexity of the GAF Monograph Project and the variety of participation which it has required can easily be deduced from the acknowledgements which follow. On the German side: General Deichmann, who, as Chief Control Officer, became the moving force behind the entire project, and his assistant, General Plocher; General Josef Kammhuber, a contributor to, and strong supporter of, the project, who became the first chief of the new German Air Force; Generaloberst a. D. Franz Halder, Chief of the German Army General Staff from 1938 to 1942 , whose sympathetic assistance to the project was of the greatest value; the late Generalfeldmarschall Albert Kesselring, who contributed to several of the studies and who also, because of his prestige and popularity in German military circles, was able to encourage many others to contribute to the project; and all of the German "topic leaders" and "home workers" who are too numerous to mention here, but whose names can be found in the prefaces and footnotes to the individual studies.

In Germany, Colonel Hammer served as Project Officer from early in 1953 until June 1957. Colonel Hammer's considerable diplomatic and administrative skills helped greatly towards assuring the project's success. Col. William S. Nye, USA, was Chief of the USAREUR Historical Division at the project's inception; his strong support provided an enviable example of interservice cooperation and set the pattern which his several successors followed. In England, Mr. L. A. Jackets, Head of Air Historical Branch, British Air Ministry, gave invaluable assistance with captured Luftwaffe documents. The USAF Historical Division 
also wishes to express its thanks to the Houghton Mifflin Company of Boston for permitting quotations and citations from volume 5 of Winston S. Churchill's The Second World War to be used in this study.

The project is indebted to all of those members of the USAREUR Historical Division, the Office of the Chief of Military History, and the USAF Historical Division, whose assistance and advice helped the project to achieve its goals.

At the Air University, a number of people, both military and civilian, have given strong and expert support to the project. The several Commanders of Air University during the life of the project in Karlsruhe (1952-58) without exception were interested in the project and gave it their full backing. Other personnel at Headquarters Air University who contributed time and experience include: the several Dixectors of the Aerospace Studies Institute since 1952; Dr. James C. Shelburne, Educational Advisor to the Commander; Mr. J. S. Vann, Chief of Special Projects Branch, DCS/Operations; and Mr. Arthur P. Irwin, Chief, Budget Division, DCS/Comptroller.

The project is grateful to Lt. Col. Leonard C. Hoffman, former Assistant Air Attaché to Germany, who gave indispensable aid during the project's last year in Germany, and to Mr. Joseph P. Tustin, Chief Historian of Headquarter8, United States Air Forces in Europe during the years when the project was at Karlsruhe, who rendered substantial assistance by solving a variety of logistical and administrative problems.

Mrs. Mary F. Hanlin deserves special thanks for her expert typing of the final draft. 


\section{AUTHOR'S FOREWORD}

In the course of the crucial battles in the East at the close of 1942 , the only important mission assigned to the Luftwaffe was that of providing for the support of the Army, usually direct support on the field of battle. This remained the Luftwaffe's main mission throughout the year 1943, and was almost exclusively dependent upon Army operations. Therefore, in this third volume on the war in Russia, it is again necessary, in fact even more than before, to treat the ground situation in some detail.

In the existing circumstances it is only natural that the many individual missions carried out by German air forces were very similar, with respect to purpose, assignment, execution, and results achieved, to the tactical support operations which had become the order of the day. Because of this, the various individual missions have not been treated in detail except in those instances in which it could be substantiated by documentary evidence that they had a marked impact upon the overall outcome of military operations. In general, an effort has been made to keep unnecessary details in the text to a minimum.

However, whenever the Luftwaffe played a decisive role in an operation, such as was the case in Operation ZITADELIE, in the battle for the Kuban bridgehead, and in the Crimea, air operations have been treated as exhaustively as available sources permitted. In this regard, the written and oral reports of many participants in these actions have been quoted and included, either completely or in part, in the body of the study.

In volumes one and two of The German Air Force versus Russia* the various operations were treated separately within the several major battle areas (army group areas) in the Eastern Theater, namely, the South, Center, North, and Far North. This could not be done in this study, since all too frequently the large-scale operations of 1943 simultaneously involved several army groups, and most of the major actions were closely interrelated between the various combat sectors. Only in Combat Zones North and Far North (First and Fifth Air Fleet areas respectively) could operations be treated in separate sections or chapters.

*Editor ${ }^{\top}$ s Note: Volumes one and two are USAF Historical Division Studies $\overline{\text { No. } 153}$ and 154 . 
Insofar as a specific critique of Army operations, their purposes, scope, and execution, are concerned, appropriate appraisals have been quoted from eminently qualified commanders such as Field Marshal Exich von Manstein and General der Infanterie Kurt von Tippelskirch.

As was true in the previous volumes, the individual chapters of this study were submitted whenever possible in preliminary draft form to actual participants in the particular actions described for their comments, criticisms, and additions. However, the author has not hesitated to express his own opinions concerning these operations, and does so in awareness that the discovery of new documents, war journals and diaries, papers, original reports and orders will more completely round out the story of these great events, and may require a modification of this work. Interpretations and judgments must always be derived from a careful study of all available data as seen in the light of historical perspective. The author wishes to express his warmest thanks to his many comrades whose contributions helped to make possible the compilation and writing of this study. May it be of interest and worth to the coming generations.

Hermann Plocher Generalleutnant (Ret.) German Luftwaffe 


\section{PREFACE}

Contrary to the considered advice of experienced military leaders, Hitler decided in 1940 to launch an attack upon the Soviet Union. Logistically the Wehrmacht was ill prepared for a long and difficult campaign in the East, and German forces were already heavily committed in many other areas. The Fuehrer confidently waved all of these arguments aside with the supremely optimistic assurance that "it would all be over in a few weeks."

The war began on 22 June 1941 and soon a number of those who had serious misgivings about the gigantic venture were overwhelmed with the almost unparalleled series of military victories achieved by German arms in the East. Within a week the Luftwaffe had swept the skies clear of the Soviet air arm and had virtually destroyed it as a fighting force. The Army was also impressive as it drove through eastern Poland, the Baltic States, Bessarabia, and deeply into the Soviet Union. Leningrad was encircled and German armored forces stood near the gates of Moscow. It began to appear that the Fuehrer's prophesies, despite all logic to the contrary, might again come to pass. Actually, Germany had reached the high-water mark of the campaign.

Hitler, always obsessed with his concepts of Lebensranm and other special ideas, especially with respect to the East, was pleased with the results of the massive encirclement battles at Minsk-Bialystok, Smolensk, Bryansk-Vyazma, Gomel, Uman, Kiev, and the area northwest of the Sea of Azov, in which 2, 256,000 Russians were taken prisoner. Yet, despite these gains and the conquest of thousands of square miles of Soviet territory, the Red Army had not been destroyed in the field, and sizeable units were able to withdraw to the east, where they helped to establish defenses in depth.

An unusually early and harsh onset of winter exposed the German Army to conditions for which it was unaccustomed and poorly prepared, and as the year drew to a close neither Leningrad nor Moscow had been taken. In the crucial winter fighting, German forces were not only compelled to fall back from the Soviet capital, but were fortunate that their withdrawal did not turn into a rout. Hitler prevented chaos in this situation through his order to "hold out at all costs" and "not to retreat a step," an expedient which he repeated again and again throughout the war, even when it appeared to serve no useful purpose whatever. 
The German Army, having suffered grievous losses, emerged seriously weakened from the winter battles of 1941-42, and, as its leaders had foretold, its failure to make adequate logistical preparations began to tell. Adequate airfields were few and far between, and the primitive unsurfaced roads which characterized the East created immense problems for mechanized forces. Severe weather conditions aggravated matters still more.

Aware of these facts, Generaloberst Franz Halder, Chief of Staff of the German Army, insisted that the Wehrmacht be allowed to rest and rehabilitate itself so that the front could be stabilized and the very unsatisfactory logistical situation improved. Plans could then be laid for a promising offensive at a later date. Hitler, whose eyes were upon the industrial complex of the lower Volga and the rich oil fields of the Caucasus, immediately brushed these arguments aside $w$ ith the comment that a Iull in the fighting would not significantly improve the German position in the East, but would simply allow the Russian giant time in which to recover from the staggering blows he had received in 1941. Moreover, if the war could be quickly concluded in the East, there would be no possibility of AngloAmerican aid attaining dangerous proportions, and the victory for Germany would morally strengthen its allies, especially Italy and Japan.

The summer offensive of 1942 laid the groundwork for Germany's defeat in the East. In these operations the relationship between the desired objectives and the forces available to secure them was faulty. The intended linkup of German forces with the Finns around Leningrad was feasible, but the southern operations required more than the Wehrmacht could handle. Hitler could not be dissuaded from his plans, and on $23 \mathrm{July}$ 1942 issued his Directive No. 45, committing the depleted and worn-out army to two widely divergent drives, one toward Stalingrad and the Volga industrial complex, and the other toward the Caucasus. This, of course, entailed an immense dissipation of German airpower, since the Luftwaffe was expected to support all of these offensives, as well as minor operations, on a front extending from the arctic area to the central Caucasus.

Logistically, there was no chance for success in the southern operations unless the Russians were foolish enough to commit the bulk of their forces in the bend of the Don River where they could be quickly encircled and destroyed. German field commanders knew this. But the hope upon which victory hung never materialized.

By September, German forces had reached the environs of Stalingrad and had driven deeply into the Caucasus area, but at the end of that 
month operations ground to a halt. The Red Army had fought successful rear-guard actions near the Don and had withdrawn most of its forces to the east. A bitter fight then ensued for the city of Stalingrad, a city which refused to surrender. On 21 November, while German forces were locked in battle in that area, the Russians opened a large-scale offensive and quickly rolled up the Italian Eighth and Rumanian Third Armies and encircled the German Sixth Army under Paulus at Stalingrad. At the time there was the even graver danger that Soviet forces might reach Rostov on the Don, cutting off an entire army group in the Caucasus.

The Sixth Army held out against tremendous odds until 2 February 1943. In the course of this struggle the Luftwaffe was unable, despite its utmost efforts, to deliver even the required minimum of food and arms to the encircled force. Thus Goering's frivolous promise that he could "supply the Sixth Army by air" proved to be an idle boast which seriously damaged his standing--and with it that of the Luftwaffe--with Hitler.

Unquestionably the resistance by Paulus' men was an outstanding achievement, but the loss of such a large force was bound to have an adverse effect upon the entire German Army and to create a psychological impact of world-wide dimensions. In the West and the Soviet Union the news of the Sixth Army's capitulation was greeted with unbounded jubilation, while in Germany the news was received by a stunned and melancholy populace. Even Germany's closest allies began to question the possibility of a German victory.

This entire defeat is clouded by another problem, that of command. Following the dismissal of Field Marshal von Brauchitsch in 1941, Hitler had assumed the additional office of Commander in Chief of the German Army. Thereafter, his conduct of operations, his continual faith in improvisations, and his habit of interfering with local decisions through a by-passing of normal command channels were to have disastrous consequences for the German war effort. The Luftwaffe, being more and more drawn into a close-support role, thus suffered accordingly. Nor were matters improved by the fact that the Luftwaffe was represented by a Colonel on the staff of the High Command of the Wehrmacht.

Stalingrad was a turning point in the war. Not only was it a grievous loss to the already weakened front, but it pointed up the multifarious shortcomings of the German Wehrmacht and the German military economy, most of which could no longer be set right.

It is in this setting that Generalleutnant Plocher begins his third volume of The German Air Force versus Russia. Facing vastly superior xiii 
forces on the ground and in the air, the German Command found itself increasingly obliged to resort to desperate measures and improvisations to avoid disaster. By 1943 the Wehrmacht was suffering from almost every conceivable sort of command, logistical, and military difficulty, and probably established a unique record in staving off the inevitable. The author discusses the operations of this year, emphasizing particularly the Luftwaffe's effort to again become a decisive weapon which could decide the outcome of the wax.

The original of this manuscript has been abridged and several of the longer quotations have been sharply reduced in an effort to improve the narrative for the reader. Extensive editing has been done by the USAF Historical Division, but in the process it has carefully preserved the character of General Plocher's work, the essence of his commentary, and the significance of the remarks and opinions of others.

In conformity to general practices arising from the difficulty of finding precise American equivalents for grades and positions of German general officers, all ranks above Colonel have been left in the German form, with the exception of Field Marshal. 


\section{ABOUT THE AUTHOR}

Generalleutnant Hermann Plocher was born 5 January 1901. His career in the German military service began in October of 1918 as an officer candidate in the 126th Infantry Regiment. He was commissioned 1 December 1922 in the 13 th (Wuerttemberg) Infantry Regiment, a unit whose junior officers included such able men as Erwin Rommel and Dr. Hans Speidel. Three years later Plocher began training as a pilot, and in 1928 went with other German officers to the Soviet Union to take special courses in aerial combat and reconnaissance during the period when such activities were proscribed in the Reich. Following his promotion to Captain on 1 April 1934 he attended the Army War College (Kriegsakademie) in Berlin, receiving special air force training, and a year later was assigned to the Organization Branch of the Luftwaffe General Staff.

In August of 1936 Plocher, then a Major, was sent to Spain as part of the German contingent to assist Generalissimo Franco, and participated actively in the Spanish Civil War. In October of 1937 he was appointed Chief of Staff of "Legion Condor." By virtue of his record, Plocher earned on 1 March 1938 an extraordinary promotion to Lieutenant Colonel.

Prior to the outbreak of World War II he was assigned to the Luftwaffe General Staff as Chief of Plans and Mobilization. He then assumed the post of Chief of Staff of the V Air Corps (redesignated 1 April 1942 as Luftwaffe Command East) on 5 January 1940 and served with this organization during its operations in the West and in the Soviet Union. On 1 February 1943 he took command and directed the formation of the 19th Luftwaffe Field Division, and in April, following his promotion to Generalmajor, went with his unit to Normandy. General Plocher assumed command on 1 July 1943 of the 4th Air Division, and in October became Chief of Staff of the Third Air Fleet (Western Front). Following his promotion on $1 \mathrm{July} 1944$ to Generalleutnant, he became Commanding General of the 6th Airborne Division (Western Front). On 10 May 1945 he surrendered to Canadian forces in the Netherlands.

From 1953 until the spring of 1957, Generalleutnant Plocher gave generous and valuable assistance to the USAF Historical Division's German Monograph Project in Karlsruhe, Germany, adding his contributions to those of his colleagues to round out the story of German Air Force 
operations during the war. On 1 March 1957 he returned to active duty as a Generalmajor in the Bundeswehr as Deputy Inspector of the Luftwaffe and Chief of the Luftwaffe Operations Staff. He later served as Commander of a Luftwaffe division and simultaneously as Inspector for Troop Service in the Luftwaffe, and completed his military career as Commanding General of Luftwaffe Group South, from which he retired 31 December 1961.

As a former commander of German air and ground forces and as a General Staff officer of considerable experience and ability, he is ideally suited to document the course of events on the Eastern Front, where he played such a significant role. 
CONTENTS

Page

FOREWORD .................... v

AUTHOR'S FOREWORD ................ ix

PREFACE .....................

ABOUT THE AUTHOR ..................

CHAPTER 1. THE BEGINNING OF 1943: CRISIS BETWEEN THE DON AND DNEPR RIVERS ........ 1

Developments on the Eastern Front 1941-1942 . . . . . 1

Battles in the Don-Dnepr River Areas, January-Mid-

March 1943 ................... 6

Fourth Air Fleet Operations Between the Don and the

Dnepr .................... 14

CHAPTER 2. LUFTWAFFE OPERATIONS IN DEFENSE OF THE KUBAN BRIDGEHEAD ..........

CHAPTER 3. LUFTWAFFE COMMAND EAST IN COMBAT ZONE CENTER OF THE EASTERN THEATER OF OPERATIONS ..............

Operations, January-July 1943, Prior to Operation

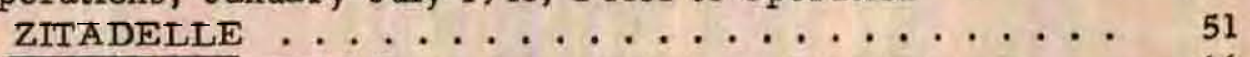

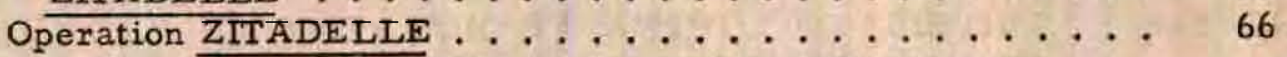

The Problem of Continued Operations in the East

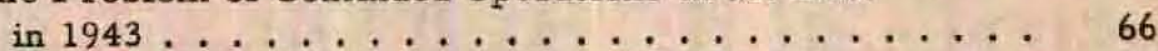
The Plan of Attack for Operation ZITADELLE . . . . 72 Preparations for the Strongest Luftwaffe Concentration for ZITADELLE .......... 75

The Last German Offensive in the Eastern Theater of Operations ............. 83

CHAPTER 4. THE AFTERMATH OF ZITADEILE . . . . . 98

The Air Battle Over the Orel Salient............ 98 xvii 
The Battles of Army Group Center in the Autumn

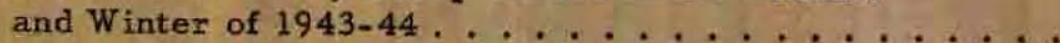

Air Operations in Combat Zone Center, Autumn-

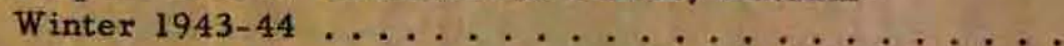

Air Support During the Withdrawal Behind the

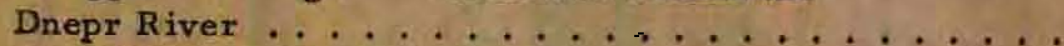

Luftwaffe Support in Defense of the Dnepr River

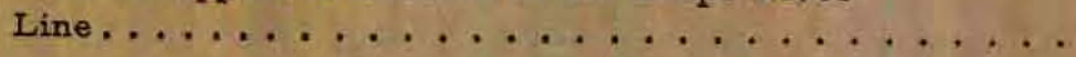

CHAPTER 5. AIR AND FLAK FOR CES IN THE BATTLE FOR THE CRIMEA .............

Luftwaffe Activity in the Crimea in the Winter of 1943-1944

CHAPTER 6. OPERATIONS IN THE NORTHERN AND FAR NOR THERN AREAS IN $1943 \ldots \ldots \ldots$

The Defensive Battles of Army Group North .......

The Luftwaffe in the Far North: Norwegian and

Barents Seas and the Murmansk Front .........

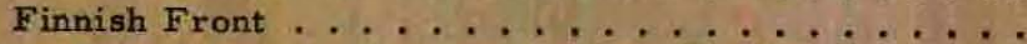

Luftwaffe Anti-Convoy Operations in the Far North,

$1943 \ldots \ldots \ldots \ldots \ldots \ldots$

Service Forces of the Luftwaffe ...............

Command Changes in Luftwaffe Forces in the

Far North...................

Summary of Far Northern Operations . . . . . . . . .

GHAPTER 7. CRTTIQUE OF LUFTWAFFE OPERATIONS IN THE EASTERN THEATER IN $1943 \ldots . .$.

Attempts To Conduct Strategic Air Warfare in the

Eastern Theater in $1943 \ldots \ldots \ldots \ldots$

German Air Operations in the East, $1943 \ldots \ldots \ldots . . .$.

The Mission ..................

High Command Organization ............

Operations of the Air Forces .............

Individual Arms of the Luftwaffe ............

Organization of the Air Forces ...........

Flak Artillery Forces ............. 
Air Signal Forces............. 2. 256

The Ground Service Organization ........ 257

Personnel Matters ............... 261

Cooperation Between the Luftwaffe and the Army

and Navy .................

Airman in the East ................. 266

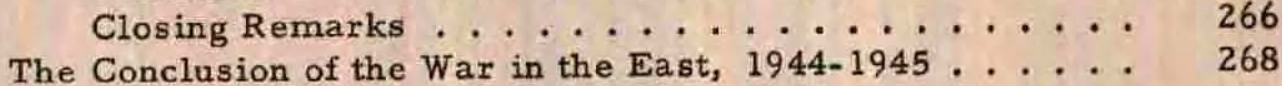

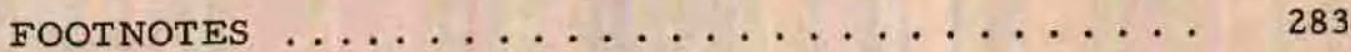

APPENDICES ................................ 317

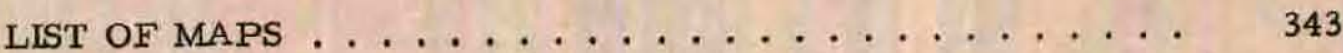

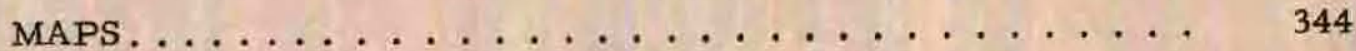

LIST OF CHARTS .................................. 361

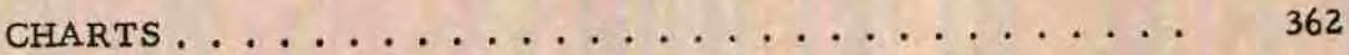




\author{
Chapter 1 \\ THE BEGINNING OF 1943: CRISIS BETWEEN \\ THE DON AND DNEPR RIVERS
}

\title{
Developments on the Eastern Front T94I- 1942
}

Hitler began his campaign against Russia (Operation BARBAROSSA) at daybreak on 22 June 1941 . He had always viewed the Soviet Union as the principal ideological enemy of the Reich and hoped to settle matters in the East through a "lightning war" so that he could be free to bring military operations against Britain to a conclusion. 1 He also hoped to secure sources of raw materials in the Soviet Union which were needed by Germany's war program and sizeable areas which could be used for German colonization.*

The Fuehrer was not alone in his anxieties concerning Soviet intentions. Many of his top military advisors shared these views, and were genuinely alarmed over the Soviet Union's aggressive and expansionist undertakings in eastern Europe between 1939 and 1941. They believed that Stalin intended to attack Germany as soon as Russia was ready for such an operation and a suitable pretext for war could be found.t

Forces available for the campaign against Russia consisted of 145 German and allied divisions, which were divided among three major commands, Army Groups South, Center, and North, and one minor command, with less critical objectives, Army Group Far North. This field army advanced from its concentration areas in East Prussia, Poland, and Rumania, overwhelming a large number of Red Army units and scoring victory after victory in rapid succession. The German and allied forces

*Editor ${ }^{1}$ Note: See Generalleutnant Hermann Plocher, The German Air Force versus Rassia, I94I, USAF Historical Studies No. 153, Maxwell AFB, Alabama: USAF Historical Division, ASI, July 1965.

tEaitor's Note: While the U.S.S.R. has always alleged that it seized the Baltic States, attacked Finland, and took Bessarabia as necessary defensive measures, these acts alarmed Germans and other Europeans, and reinforced Hitler's conviction that a preventative war against Russia had to be made as soon as possible. 
surged steadily eastward through the dust of the summer, deep into the vast expanses of Russia, taking thousands of prisoners and capturing massive amounts of enemy materiel.

At the same time the Luftwaffe demonstrated its power by immediately destroying the bulk of the largely obsolete Soviet Air Force and quickly establishing air supremacy over the entire Eastern Theater of Operations. So devastating was this air blow that it might have been a decisive factor had the Luftwaffe also been able to destray the sources of Soyiet military power and to interdict the flow of materiel through the ports of the Black and Caspian Seas, and through Arkhangelsk and Murmansk. These goals were never attained.

By October 1941 the Wehrmacht was poised for what the German High Command then believed would be the final assaults upon the strategic objectives of Moscow and Leningrad. In November, however, serious logistical difficulties, including shortages of winter clothing and equipment, unexpectedly fanatical enemy resistance, and an unusually early and severe onset of winter, slowed the German attack along the entire front. By 5 December the great offensive had come to a halt and the key cities of Moscow and Leningrad remained in Russian hands.

During these operations, Russian troops, assisted by mass civilian labor forces, exhibited surprising ability to rehabilitate their units, evacuate heavy equipment, and make hasty improvisations in defense lines and field fortifications. Moreover, they were able to withdraw large numbers of troops to the East before the German forces could surround and destroy them. * In these encounters the individual Russian soldier proved to be a cunning and ruthless adversary, skilled in the use of cover and concealment, and able to endure great physical hardships and privations.

Having failed to secure the strategic objectives of the campaign by the end of 1941, the German Army then found itself forced to fight off heavy Soviet counterattacks launched by newly arrived Siberian units, and, being critically short of supplies and manpower, had to withdraw from its advanced positions and go over to the defensive. Only by implementing the most stringent measures, including the Fuehrer's order

*Editor's Note: See Generalleutnant a. D. Klaus Uebe, Russian Reactions to German Airpower in World War 프, USAF Historical Studies No. 176, Maxwell AFB, Alabama: USAF Historical Division, ASI, July 1964, pp. 1-6, 83-89. 
of 16 December 1941 to hold fast "without retreating a step, "was the Wehrmacht able to avert a disaster of immense magnitude near Moscow. 2 With considerable intrepidity and great resourcefulness, German and allied forces were able by the end of January 1942 to check the Soviet counteroffensive and to shorten their front lines for more effective defense.

On 12 February 1942 the German High Command issued orders for a resumption of the offensive, to begin as soon as logistical and weather conditions were propitious. Hitler was certain that the 1942 campaign in southern Russia would be a decisive victory if it resulted in the seizure of the Caucasus oil region. Such a plan, however, entailed the assumption that the Russians would be willing to commit the greater part of their forces in the area of the Don River bend, where the Wehrmacht could envelop and destroy them. *

Hitler issued on 5 April his Directive No. 4 I (Operation BIA U), which outlined a four-step plan for the conquest of the Caucasus and, providing all conditions were favorable, for the seizure of Leningrad as well. While Army Group Center was to hold its position, Army Group North in conjunction with its Finnish allies was to seize Leningrad. In Combat Zone South, the offensive was to begin with a breakthrough in the Kursk area by left flank units (Fourth Panzer Army and Hungarian Second Army) of Army Group South, thereby opening the way for a pincers operation against Voronezh. The two armies were then to advance southeastward, linking up with the Sixth Army thrusting eastward along the Valuy River from Kharkov. These combined forces, spearheaded by strong armored and motorized units, were then to make a rapid advance along the Don to the southeast, meeting near Stalingrad the First Panzer Army and Seventeenth Army of Army Group South, which were to make a swift drive toward the Don River from Taganrog. It was assumed that this would envelop the bulk of the Red Army in the Don River bend and clear the path for a general advance into the Caucasus. All movements were to be made from one phase line to another, making the most judicious use possible of available forces by concentrating maximum force at the crucial points of battle.

*Editor's Note: See Generalleutnant Hermann Plocher, The German Air Force versus Russia, 1942, USAF Historical Studies No. 154, Maxwell AFB, Alabama: USAF Historical Division, ASI, 1966. See also Maps Nos. 1 and 2. 
The summer offensive was launched at the end of the muddy season and by July German forces had advanced to the Don River along a front extending from the area north and east of Orel into the bend of the Don, and thence to Rostov in the south. At this juncture, a radical change was made in the overall plan of attack. On 23 July Hitler issued Directive No. 45 , setting forth two principal objectives for a continued offensive in the East, the seizure of Stalingrad and the lower Volga industrial complex, and the conquest of the Caucasus oil region. 3* In his thinking the Fuehrer without doubt was heavily influenced by logistics and by the conviction that the Red Army must be suffering equally as much as the Wehrmacht from the material and personnel losses of previous operations. Therefore, he was tempted to concentrate upon the seizure of the Caucasus oil fields, which seemed to be much more important to Germany's war effort than the conquest of Moscow, which continued to be urged by some of the German High Command. $f$

In order to implement his plan, the right wing (Eleventh Army and Third Rumanian Army in the Crimea, and the Seventeenth Army and First Panzer Army in the northern Caucasus) of Army Group South was, by late July, redesignated Army Group "A." The remaining forces of Army Group South (Second and Sixth Armies, Fourth Panzer Army, and Hungarian Second Army, with the Rumanian Fourth and Italian Eighth Armies in reserve) were placed under the newly organized Army Group "B."

Army Group "B" was to drive down the Don to Stalingrad to secure the lower Volga River area, while Army Group "A" was to seize Rostov and the Caucasus oil region. Since these drives were virtually at right angles to each other, they violated the principle of advance by phase lines which, until then, had been so successful.

By mid-November Army Group "A" had driven to the Kuma River as far as Alagir and to Mt. Elbrus, deep in the Caucasus, and from thence to the area west of Tuapse, to Iskaya, and then to the Black Sea coast near

*Editor's Note: See Generalleutnant a. D, Hermann Plocher, The German Air Force versus Russia, 1942, USAF Historical Studies No. 154, Maxwell AFB, Alabama: USAF Historical Division, ASI, 1966, for a more complete discussion of these operations.

†Editor's Note: Generaloberst Franz Halder, Chief of the General Staff of the German Army, 31 August 1938-24 September 1942, thought that the Russians would be willing to trade space in southern Russia for time, while an offensive in the center toward Moscow might well have succeeded. 
Novorossiysk. Army Group "B" had advanced to the Don from the area west of Yelets, and its Sixth Army had reached the vicinity of Stalingrad, while motorized units of the group had penetrated as far southward as the Elista area in the northern Caucasus. * Logistical problems began to mount enormously, and the cost of the offensive was taking a heavy toll of men and equipment in both army groups, especially in the Sixth Army of Army Group "B, " which continued to exhaust itself in futile attempts to take the city of Stalingrad.

On 19 November the Red Army opened its first massive counteroffensive of the war all along the Don front from Stalingrad to the area west of Serafimovich, breaking through the left side of the Third Rumanian Army front and rolling up the right flank of the Italian Eighth Army immediately to the north. Within two days the Russians had driven as far as Kalach-on-the-Don, where they reached spearhead units of strong Soviet forces driving westward from Krasnoarmeysk, and on 22 November had completely encircled the Sixth Army, together with elements of many other German and allied units, in a large pocket west of Stalingrad, $f$

Realizing that the Sixth Army was already critically short of supplies and replacements, and exhausted from months of heavy fighting, several senior Army and Luftwaffe commanders attempted to persuade Hitler either to withdraw the forces from the Caucasus or to approve a Sixth A rmy breakout to the southwest, since the encirclement of the Sixth Army, serious as it was, might also be the prelude for a concerted Russian drive on Rostov. If that city could be reached, an entire German army group would be cut off in the Caucasus. The Fuehrer, however, assured by Reichsmarschall Hermann Goering that the Luftwaffe could supply all of the entrapped army's needs by air, ordered the Sixth Army to hold at "all costs, " and directed the Luftwaffe to establish an airlift to give it all necessary logistical support.

Generaloberst Hermann Hoth and his Fourth Panzer Army then tried to extricate the Sixth Army by a relief attack from the southwest. When his relatively weak force had reached its farthest point of advance, a junction with the encircled army might have been possible if Generaloberst Friedrich Paulus, the Sixth Army Commander, had been willing

*See Map No. 1. The Eleventh Army (Generaloberst Erich von Manstein) was transferred 18 September 1942 to Army Group North, but returned to become the framework for the new Army Group Don 22 November 1942.

tSee Map No. 2. 
to defy his Fuehrer's orders and make a southwesterly dash over the remaining few miles between the armies. This, he was unwilling to do.

The airlift operation was equally ill-fated, since the forces on hand for the undertaking were grossly inadequate even at the outset, especially in view of the fact that the Luftwaffe had to help stem the tide of Soviet attacks on an immensely broad front. Robbing school and training installations of their last transport aircraft did not materially alter the situation at Stalingrad, since the attrition rate was always higher than the rate of replacement. This serious condition was further compounded by acute shortages of personnel, tools, replacement parts, combat aircraft, and other types of supplies and equipment, all during a period of extended adverse weather. It is, in fact, surprising that the Luftwaffe's airlift functioned as well as it did. Yet, despite heroic sacrifices, German air units never came close to the minimum objective of maintaining the Sixth Army's supply levels, much less to the creation of reserve stockpiles.

Operations in 1942 were shattering, and every German effort appeared to have been made in vain. One German army and three of its allies' armies had suffered devastating losses, with at least 50 divisions completely destroyed. Other losses amounted to the strength of about 25 divisions. Along with this were lost incalculable quantities of heavy infantry weapons, light and heavy artillery pieces, tanks and assault guns, and other materiel, an aggregate which was definitely heavier than the losses inflicted upon the enemy during this period. But by the far the most significant losses for Germany were in personnel, since the Soviets, despite their heavy losses, still had far greater reserves of manpower at their disposal.

\section{Battles in the Don-Dnepr River Areas, January-Mid-March 1943}

At the beginning of January 1943 the Soviet forces held the initiative in every sector of the entire Eastern Theater of Operations. In the southern area (the main zone of combat operations for the German Army and Luftwaffe at the turn of the year), the critically weakened German armies were, generally speaking, back in the positions from which they had commenced their great offensive of July 1942 . The Russian hordes had continued to strengthen their attacks along the breakthrough areas in the sectors held by Rumanian, Italian, and Hungarian armies, and threatened to bring about a collapse of the entire front in Combat Zone South. If the Soviet Command could achieve its objectives, 
the result could be far more disastrous than the threatened loss of the Sixth Army at Stalingrad, since a catastrophe involving two German army groups could decide the outcome of the war.

Generaloberst Paulus' Sixth Army, acting as a breakwater in advance of the German lines, was still holding out in Stalingrad at the turn of the year, but its fate was already sealed. $4 *$ All efforts to relieve it or to enable it to break out to the south or southwest had failed, and the army's end was fast approaching. It could, at best, do no more than contain sizeable Soviet forces for a short time by expending its last forces. In this way it could render a positive service to German comrades in the Caucasus who also were threatened with encirclement. 5

East of the Don and Donets Rivers, from the area just south of Morozovsk to the Manych River, Generaloberst Hoth's Fourth Panzer Army, together with the remnants of the Fourth Rumanian Army, were withdrawing west of the Don and Donets along a line extending from Voroshilovgrad to the western Manych. The mission of these armies was to protect the rear of the First Panzer Army (General der Kavallerie Eberhard von Mackensen), then withdrawing from the Caucasus, from Soviet attacks from the region of Millerovo and Kamensk-Shalkhtinsky. At the same time, the Fourth Panzer Army and its auxiliary units had to prevent a Soviet breakthrough along the lower Don River in the direction of Rostov. If the Russians could reach the Don estuary, they could cut off the Fourth Panzer Army and all of Army Group "A," the latter being made up of the First Panzer Army and the Seventeenth Army. $6 f$

In the critical situation the important thing for the Fourth Panzer Army was not to expend its forces by attempting to offer strong resistance along a broadly extended front, but, rather, to keep its forces tightly concentrated. This was the only way it could render tenacious resistance at crucial points, as the situation might require, or exploit opportunities for surprise blows. It was therefore self-evident that the army at times had to strip certain areas completely, and leave other areas with only a thin defensive covering line.

*Stalingrad officially surrendered to the Red Army 2 February 1943. See Map No. 2.

tEditor's Note: Army Group "A" was under the overall command of Generaloberst Ewald von Kleist. Rostov was not only strategically important for German operations in 1942, it was also Army Group "A's" supply center. 
Ably supported by his excellent chief of staff, Generalmajor Friedrich Fangohr, Hoth accomplished his difficult mission by a determined, but flexible, conduct of operations.* Employing clever tactics, he succeeded in delaying the Russians in their hot frontal pursuit, without exposing his force to the threat of a defeat by holding out too long in a given position. He also managed to concentrate his forces quickly in brief attacks against Soviet troops on his flanks, thereby repeatedly thwarting their attempts to outflank and surround his army. 7 Hoth's operations were all the more outstanding because of the bitter winter conditions in which his units were forced to fight, often with bare minimums of supplies and equipment.

Meanwhile, Army Force Hollidt (Generalleutnant Kar1 Hollidt), holding the left flank of Army Group Don (Field Marshal Erich von Manstein), immediately north of the Fourth Panzer Army, employed its weak forces again and again to prevent attacks from the north, or, what could have been worse, from the northwest against the rear of the Fourth Panzer Army, If With the "valuable support of flak artillery units under the tried and proven command of Generalmajor [Rainer] Stahel, "Hollidt's force was able to hold up the Soviet advance at the Chir River and later at the Donets River. 8

Army Group "A" found itself in an increasingly difficult situation in the Caucasus. It should really have been clear to the Supreme Command from the outset that this unit could not maintain its forces there unless the envelopment of the Sixth Army could be broken very quickly. In other words, it was essential to reestablish a relatively stable situation in the main bend of the Don River. Once the Russians had breached

*Editor's Note: Manstein mentions that Hoth's naturally "impulsive" nature was perfectly offset by the presence of Fangohr. See Generalfeldmarschall Erich von Manstein, Verlorene Siege (Lost Victories), Bonn: Athenaeum Verlag, 1955, p. 534. Cited hereafter as Manstein, Lost Victories.

fFormed in November 1942 and continued to be so designated until 3 February 1943, when it became the nucleus of a reconstituted German Sixth Army.

IfEditor's Note: The Fourth Panzer Army's front faced to the north, east, and southeast in the area northwest of Elista. By 1 February 1943 it faced the same directions from the confluence of the Manych and Don Rivers to the confluence of the Donets and Don, and thence to the west as far as the Voroshilovgrad area. See Maps Nos. 1 and 2 . 
the right flank of Army Group "B" (Army Force Fretter-Pico, * Second Army, Hungarian Second Army, and Italian Eighth Army) northwest of Morozovsk and opened the way for their drive on Rostov, however, it must have been perfectly obvious that the Caucasus front could not be held under any circumstances. $9 f$

On 29 December 1942 Hitler had ordered the withdrawal of the First Panzer Army, operating on the eastern flank of Army Group "A, " the area which was most seriously threatened by the Soviet affensive. For the time being the army was to withdraw to the Pyatigorsk-Praskoveyskiy segment of the Kuma River line. It was, of course, evident that this was not to be the last move and that the entire Caucasus would eventually have to be evacuated.

Evacuation of the Communications Zone of Army Group "A, " involving the movement of hospitals, ammunition and food supply dumps, permanently installed weapons, and other essential items, was an exceedingly difficult and time-consuming operation. 10 One of the major obstacles to be overcome was the lack of high-carrying-capacity rail and road routes, particularly in the mountainous areas. In spite of these difficulties, however, the first Panzer Army succeeded by mid-January 1943 in retiring to positions along a line extending approximately from Cherkassk to Petrovskoye. It was still separated from the Fourth Panzer Army by a wide gap extending all the way from the area north of Cherkassk to the vicinity of Proletarskaya, a part of which area was impassable for large units even in the winter because of the Manych River swamps.

Covered by the Fourth Panzer Army and with constant support from units of the Fourth Air Fleet, the First Panzer Army in a series of seesaw battles, which included numerous defensive counterattacks, finally succeeded in withdrawing the bulk of its forces across the Don River on both sides of Rostov. There, the army was placed under the command of Army Group Don (von Manstein) and took up positions on the left flank of that organization. The divisions of the First Panzer Army retired across the Don River into the area back of the main line of

*Editor's Note: Under the command of General der Artillerie Maximilian Fretter-Pico, this unit was formed 25 December 1942 and became a part of the First Panzer Army on 3 February 1943.

tSee Maps Nos. 2 and 3. 
resistance just in time to support Army Group Hollidt, then hard pressed between the Don and the Mius Rivers; Iater, the First would play a decisive role in cooperation with the Fourth Panzer Army, withdrawing across the Don, in defense against a Russian breakthrough of the Dnepr River line. $11 \%$

The Seventeenth Army was deployed on both sides of the Kuban River in the Kuban bridgehead (later to become famous), its front extending in a line from Novorossiysk to Krymskaya, to Kiyevskoye, to Krasnyy Oktyabr, to the area east of Temryuk, 12 The German Command had to maintain strong ground and air forces to hold this position, and these forces were more urgently needed in the Donets Basin area, where they could have been used far more effectively. In the words of Field Marshal von Manstein:

.. a force about 400,000 strong remained more or less inactive in the Kuban bridgehead. The bridgehead admittedly tied down Soviet forces of considerable strength, and the Russians made several abortive attempts to eliminate it, but the bridgehead never attained the strategic significance for which Hitler had hoped. After all, the Russians were free to decide just what troops they would leave in the area to contain the German forces in the bridgehead. Another reason advanced by Hitler for the retention of such a large force at the Kuban River was the necessity of denying the Soviets possession of the naval port of Novorossiysk. However, this reason was also invalid. The port had to be abandoned anyway. $13 t$

On 2 February 1943 the battle for Stalingrad ended, bringing to a close the Sixth Army's tragic struggle in its forlorn post. 14 This resulted not only in a merciless captivity for thousands of battle-weary German troops and in the capture of enormous quantities of valuable military materiel, but also in the release of strong Soviet forces which had hitherto been required for the envelopment and reduction of the Stalingrad pocket. These forces considerably increased the power of the Red Army

*See Map No. 2 .

f Units in the Kuban bridgehead area were supplied from the Crimea. 
units attacking along the lines in the southern combat areas, where the Russians already enjoyed a vast numerical and logistical superiority. $15 \%$

Powerful Soviet forces landed near Novorossiysk on 4 February, and all efforts by the Wehrmacht to dislodge and destroy them failed. The only German achievement in the area was the compressing of these enemy forces into a narrow bridgehead. 16

Early in February the entire army command in Combat Zone South was reorganized. 17 Army Group Don was redesignated Army Group South, and assigned to command all forces in the area extending from Rostov-onthe-Don to the Kharkov-Belgorod region. This included Army Force Hollidt (later to be the core of the reconstituted Sixth Army), in position at the Mius River; farther to the north the Army Force Fretter-Picot (later under the command of the First Panzer Army), holding the area around Artemovsk; the Fourth Panzer Army in the area northwest of Stalino; and Army Force Kempitt (formerly under Generalleutnant Hubert Lanz), then in the process of reorganization in the Kharkov area. Army Group "B" headquarters was withdrawn and the Second Army, hitherto under its control, was assigned to Army Group Center.

Before this reorganization Army Force Lanz had been assigned the double mission of attacking in the direction of Losovaya to relieve the left flank of Army Group South and to hold the city of Kharkov at all costs. It was impossible to carry out either of these missions, especially the latter, but Hitler viewed Kharkoy, the capital of the Ukraine, as a prestige symbol and refused to consider a withdrawal. Under the pressure of overwhelming enemy forces, the Wehrmacht had to withdraw from the city on 15 February. Fortunately, the withdrawal was made by the SS Panzer Corps, a unit comprising the core of Army Force Lanz (and later Kempf), so that no retaliation was taken against an army commander.

From the end of February to mid-March the tide turned and parts of the Soviet forces which had broken through the German defenses and

*Despite reinforcements, the Germans were outnumbered by Red Army troops in the southern sectors by 8 to 1 , and in certain parts of the front the ratio was even less favorable for the Wehrmacht. See Manstein, p. 450 .

fEditor's Note: See p, 9.

tfEditor's Note: Generalleutnant Franz Werner Kempf. 
advanced to the vicinity of Zaporozhye and Dnepropetrovsk were enveloped by the Wehrmacht in numerous counterattacks between the Dnepr and Donets Rivers, and the bulk of the Russian forces in this area escaped destruction only by rapid withdrawals across the Donets River. * Operations against Soviet armored and cavalry forces which had cracked the Mius River defenses north of Taganrog and at Debaltsevo, west of Voroshilovgrad, also ended with the destruction of the enemy farces.

By mid-March the front in Combat Zone South was again firmly integrated and all of the divisions in this area were contiguous to each other, forming a line (albeit thinly manned in places) extending from Taganrog to Belgorod. On $15 \mathrm{March}$ the city of Kharkov was again in German hands, and replacements had filled many of the gaps created in Wehrmacht line units during the bitter defensive battles of the previous winter. From that time on, however, the onset of the muddy season prevented a continuation of operations, even those on a small tactical scale.

In a review of the overall course of the winter campaign of 1942 43 in southern Russia, and of the results achieved in those battles, it becomes undeniably apparent that the Soviet forces achieved a considerable amount of success. Yet, despite these great gains, the Saviet Command had not accomplished its decisive objective in this area, the destruction of the German southern flank, a victory which would probably have been impossible for the Wehrmacht to offset. Instead, at the conclusion of the winter campaign, the initiative along the entire front passed again to the German side. The Russians had suffered defeats in the area west and southwest of Izyum and around Kharkov, which, although not decisive in character, enabled the German command to stabilize the entire front.

At this juncture it seems proper to enumerate the factors which contributed to the victory that strengthened the German position and prevented the envelopment of the Wehrmacht's southern flank. It must be stated here that Army Group South would not have been able to overcome its initial defeat if the German troops and their officers had not demonstrated almost superhuman resistance and performed in an outstanding manner in the course of these battles, if the courageous infantry divisions had not stood their ground again and again although badly outnumbered

*See Maps Nos, 2 and 3.

tSee Map No. 4. 
by the enemy, and if the Wehrmacht, unlike its allies, had not resisted Soviet armored attacks by closing ranks after breakthroughs, thereby making possible the destruction of Russian tank forces.

In like manner, it would have been utterly impossible to have conducted this winter campaign successfully if the panzer divisions, fighting with incomparable flexibility, had not multiplied their effectiveness by striking the enemy in one area on one day and in another area on the next. It was the constant feeling of personal superiority over the enemy which enabled the German troops to withstand the severest crises, and lent the extra impetus to their courage and devotion to duty, which to a great extent offset the numerical superiority of the Russian forces.

Nor must one forget that the courageous Sixth Army, by its resistance to the last, prevented an annihilating Soviet victory in the southern sector of the Eastern Theater of Operations. If that army had not resisted long after its situation became hopeless, the Russians could have thrown strong additional forces into the decisive points of the front, which, in all probability, would have meant the envelopment of the entire German southern flank.

As Field Marshal von Manstein points out:

Although the sacrifices made by the troops of the Sixth Army may appear to have been futile in view of the final outcome of the war, nothing can detract from the ethical value of those sacrifices.

Therefore it is only right that the Sixth Army should once again be remembered in closing this presentation of the winter campaign. The troops of that army rendered the greatest service which can be asked of soldiers: to support their comrades by resisting to the last round when in a hopeless situation. 18

Reading this glowing tribute by the responsible army commander to his officers and men, it seems strange that no mention is made of the tireless and costly efforts of the Luftwaffe in trying to support the fighting men at Stalingrad. The losses suffered in airlift operations to the Stalingrad pocket are well known. Those operations were, unfortunately, futile. They failed because of inadequate forces, which were further hampered by the impact of natural forces in the almost limitless spaces of Russia. These conditions also frustrated all of the German Army's efforts to relieve and extricate the encircled Sixth Army. 
It is therefore more than unjust that Army circles for reasons unknown to the author tend to ignore and overlook the important, and sometimes decisive, roles played by the Luftwaffe in surmounting serious crises and in reestablishing firm main lines of resistance in Combat Zone South.

\section{Fourth Air Fleet Operations Between the Don and the Dnepr}

At the beginning of 1943 , the Fourth Air Fleet, commanded by Generaloberst Wolfram Freiherr von Richthofen, had the following missions to perform in Combat Zone South:

(1) To move supplies by air to the mortally stricken Sixth Armay enveloped by the Red Army at Stalingrad, and

(2) To provide air support for German and allied ground forces in their difficult, and frequently critical, battles, 19

For the accomplishment of these tasks the Fourth Air Fleet controlled the VIII Air Corps (Generalleutnant Martin Fiebig), which was engaged in combat and supply missions in support of the Sixth Army;20 Air Division Donets (Generalleutnant Alfred Mahnke), primarily engaged in operations to support the hard-pressed Army Force Hollidt; the IV Air Corps (General der Flieger Kurt Pflugbeil), then committed in support of the delaying battles of the Fourth Panzer Army and the remnants of the Fourth Rumanian Army withdrawing across the Manych River toward the lower Don; the Royal Rumanian Air Corps, employed in tactical operations between the Don and Manych Rivers; and Luftwaffe Group Caucasus (Staff of the I Air Corps under General der Flieger Otto Dessloch), supporting the First Panzer Army and the Seventeenth Army in their withdrawal from the Caucasus. 21

The command staff of the Fourth Air Fleet was established on a headquarters railway train and had moved to Taganrog South. Flying units of the Fourth, whose effective fighting strength had been reduced below the level of operational effectiveness, and all usable materiel, especially operational aircraft, were utilized to bring other units up to strength. Insofar as was possible, personnel were sent to the Communications Zone for rest and rehabilitation for their later return to the front.

Weather conditions in the south around the turn of the year were unsettled, days with relatively good visibility or high cloud ceilings being followed by days with heavy fog, low cloud ceilings, snow, rain, and ice storms. German air units operated to the maximum extent possible 
in these conditions, supporting all areas of the far-flung front from the Caucasus to the Don and Donets River areas to the vicinity of Kharkov. 22\%

The ceaseless Soviet attacks, the deep penetrations, and dangerous breakthroughs in the German front, all threatening the withdrawal routes of Army Groups "A, "Don, and "B," and the Wehrmacht retrograde movements, alternating with counterattacks to protect the withdrawals, obliged the Fourth Air Fleet to adopt extremely flexible tactics in the employment of its units, and to constantly shift the emphasis of its support operations. 23

Owing to the lack of mobile army reserves, especially panzer and motorized divisions, the usually bottomless Russian roads, the irregular pattern of the main lines of resistance, and the immense distances involved, the Luftwaffe was the only highly mobile instrument available to the German Command to stop the Red Army threats, or to slow down enemy advances so that German ground forces could reestablish defensive positions. An example of such action could be seen in the operation of 10 January 1943, when Army Force Hollidt, ably supported by Air Division Donets, succeeded in halting a Soviet armored attack and in cleaning out an area of Russian penetration.

In the course of these operations it frequently became necessary to open the way for isolated or enveloped army units to make their way back to the German lines. The garrison of Chertkovo, which had been surrounded by the Red Army for weeks, fought its way back to the German lines in the night of 15 January and during the following day. Early on 16 January the group became involved in a Soviet tank attack and suffered heavy losses from enemy tank and artillery fire, backed by mortar and multiple rocket launcher (Stalinorgel) fire, but strong support by German air units and the 19th Panzer Division enabled 15,000 German and Italian members of the withdrawing group to arrive in Streltsovka during the next two days, $24 t$

\footnotetext{
*See Map No. 3.

tEditor's Note: This was a considerable undertaking, since it involved a withdrawal under adverse conditions, beginning with a breakout, and with rear guard actions all of the way. Chertkovo is situated north of the Don River, about 100 miles east of Rostov, and Streltsovka is located in the vicinity of Voroshilovgrad.
} 
The gap between the left flank of Army Group South and the right (southern) flank of Army Group Center* provided an avenue through which Soviet forces were able to advance toward the west with practically no interference. Occasionally these enemy forces were halted by heavy German air attacks and, in a few instances, some of them were even compelled to withdraw because of timely Luftwaffe intervention. 25 Repeated and concentrated air attacks forced the Russians to withdraw from the gap between the VII and LV Corps, where they had penetrated as far as the Kursk-Orel railroad. $26 f$

On 20 January the Russians assaulted the lower Manych River line in Combat Zone South with the intention of driving through to Rostov and Bataysk. If they had achieved a breakthrough there, the First and Fourth Panzer Armies would have been cut off in the course of their withdrawal movements to the west. Therefore, all available units of the Fourth Air Fleet in the area were concentrated to attack and destroy Soviet armored units spearheading the enemy attack, with the result that the Soviet breakthrough toward Rostov was solidly checked. This success was due exclusively to the immediate concentration of German air power at the crucial point of battle.

Strengthened by unusually heavy support from bomber and tactical support units of the IV Air Corps, German forces on 27 January repelled the Red Army units attacking the front of the Seventeenth Army south of Krymsk. The powerful Soviet forces opposing the LVII Panzer Corps of the Fourth Panzer Army were badly decimated in the action.

In the ensuing days strong bomber forces of the IV Air Corps also carried out repeated attacks against Soviet units advancing toward Rostovon-the-Don and toward the Sea of Azov to the south of Rostov. On 12 January 1943 the Seventeenth Army began its withdrawal from the mountainous area near the famous peak Mt. Elbrus. Its objective was to reach the area which became known as the Kuban bridgehead. If To accommodate to this defensive situation, the Luftwaffe Group Caucasus was redesignated on 27 January as Luftwaffe Group Kuban.

Near the end of January, Soviet air activities increased steadily. Airfields and rail depots in the rear areas were frequently attacked by

*Army Group Center was strengthened on 14 February 1943 by the addition of the Second Army.

tSee Map No. 2.

t+See Map No. 5 . 
Russian air units, both by day and by night, which necessitated stronger and more effective antiaircraft defenses for all airfields and supply routes in the Communications Zone. Everything available was pressed into service to build up the antiaircraft forces, especially at Zaporozhye and Dnepropetrovsk, in order to protect the Dnepr River bridges. At the same time, flak units employed in ground combat were required to establish a supporting line in the Dnepr sector between Zaporozhye and Dnepropetrovsk. Responsibility for establishing and developing these defenses was placed in the hands of Generalmajor Rainer Stahel, an officer who had proven himself again and again in the most difficult situations. 27

\section{Early in February powerful Soviet units crossed the Donets River} on a broad front northwest and west of Lisichansk. Emphasis in Luftwaffe aerial operations was then immediately shifted to the left flank of Army Group Don. Once again, all available forces of the Fourth Air Fleet were concentrated under the command of Air Division Donets to halt the Soviet advance across the Donets River. While enemy crossings were being made at Lisichansk, Red Army units landed at three points near Novorossiysk. Two of these beachheads were eliminated immediately, but Soviet forces succeeded in maintaining and reinforcing the third. ${ }^{28}$ The possibility of Soviet amphibious operations of this type had long been a source of concern to the German Command, and armed aerial reconnaissance missions had been flown regularly over the Black Sea ports, especially Gelendzhik, Tuapse, and Poti. Conspicuously heavy concentrations of shipping had been noted at Gelendzhik, and very frequent heavy bombing and aerial mine-laying operations had been carried out against this port with gratifying results.

The increasing Soviet air activity in the Caucasus and Kuban areas also obliged the Fourth Air Fleet to attack all recognized enemy airfields which appeared to be in operation.

The tragic end of the Sixth Army* had released the units of the VIII Air Corps for a new assignment. This force was accordingly sent into action to provide air supply and combat support for the Seventeenth Army in the Kuban bridgehead. 29 A considerable supply operation was necessary to maintain the Wehrmacht forces in the Taman Peninsula,

*Editor's Note: On 31 January 1943 the command staff of the Sixth Army surrendered to Russian forces. A few units still held out, however, until the official capitulation on 2 February. 
and the movement of supplies by naval barges could be accomplished only after German air units cleared the way by destroying drift ice barriers in the Straits of Kerch by bombardment.

After 18 February, Headquarters, Fourth Air Fleet, still situated on a railway train, conducted operations from its new lacation at Chortiza.* The main ground effort, and therefore also the principal focal point for air operations, in mid-February was in the northern part of Army Group South (formerly Army Group Don), which was threatened with envelopment by a wide sweeping Soviet flanking maneuver. In this area strong enemy armored and cavalry forces were advancing with speed toward the bend of the Don River at Dnepropetrovsk, Zaporozhye, and the Sinelnikovo railway depot.

At this time the radio intercept service of the Fourth Air Fleet intercepted Russian radio messages revealing the intentions of General Markian Popov's Soviet armored corps, its critical shortage of fuel, and its location. With such a unit almost immobilized because of a lack of fuel, the time was highly opportune for a concentrated air attack. 30 Mustering all of its available bomber and tactical support aircraft, the IV Air Corps carried out very effective attacks in the Pavlograd-Kramatorsk area against Popov's tanks, halting the enemy advance, and eliminating all of the tanks which had advanced upon Zaporozhye. 314

General Popov himself admitted that his rapid advance was brought to a halt by the ceaseless assault by the Luftwaffe. Because of the gratifying results of these air attacks, the German Army which arrived later on the scene was able to drive back the remnants of the enemy armored force. This successful operation by the IV Air Corps is but one example of the action taken by the Luftwaffe before ground forces could be brought to bear in the area, thereby averting the threat of an impending envelopment.

In February a special antitank air unit was organized under the command of Lt. Col. Otto Weiss. 32 This unit was comprised of groundattack and twin-engine fighter aircraft, which were employed on many occasions with conspicuous success against Soviet tanks which had penetrated into the German rear areas. The effectiveness of the new arm was

*Editor's Note: The precise location of this point cannot be determined, but it is presumed to be in the vicinity of Zaporozhye.

The attacks against Soviet armor near Zaporozhye were carried out by $\mathrm{Ju}=88$ units. 
proven by the fact that during the Soviet armored breakthrough in the small bend of the Don River a few small antitank air units set ten Russian tanks afire and scored observed hits on a number of other tanks in the two-day battle. During this time, other dive-bomber and bomber units went into action in the area and achieved practically no successes whatever. In assessing the value of antitank air units one should not consider merely their destructive power in stopping enemy forces, but also the very favorable influence exerted by them upon the morale of friendly troops, a factor which should not be underestimated.

From the beginning of March 1943 the Fourth Air Fleet directed its main effort toward the support of the offensive of Army Group South (First and Fourth Panzer Armies and Army Force Kempf), whose objective was to regain the Donets River line. It was fairly clear that the Russians, having failed to achieve very much in their latest attacks between the Donets and Dnepr Rivers, were no longer as strong as they had been along the front of the First Panzer Army, and it appeared that the Wehrmacht stood a good chance of regaining its Donets position in that area.

The first task, however, was to beat the southern wing of the Soviet forces around Kharkov in order to give the army group a free hand to cross the Donets on a broad front. The only problem which might seriously complicate the advance was an early onset of the muddy period. By 2 March the enemy had taken a severe beating in the first counterattack by the Fourth Panzer Army and the left wing of the First Panzer Army in the area between the Donets and the Dnepr. Army Force Hollidt also performed well in repulsing Soviet attacks along the Mius River line. So badly were the Russians beaten, especially in the area of earlier penetration near Army Force Kempf, that they were no longer fit for effective combat. Three Soviet infantry divisions and the Soviet XXV Armored Corps were destroyed, and many other enemy units badly decimated in the contest. According to the German count, 23,000 Red Army troops had died in the encounter between the Donets and Dnepr Rivers, while 9, 000 prisoners, 615 tanks, 354 guns, 69 antiaircraft pieces, and immense quantities of small arms were captured. 33

By 5 March the Fourth Panzer Army had driven to the Berestovaya River and faced the southern wing of the Russian forces defending Kharkov. Many of the enemy forces in advance of the army were already decimated by earlier battles, yet a German frontal attack was sure to be costly. Enveloping maneuvers were not favorably considered because of the prevailing weather conditions. Since the ice over the Donets was beginning to break up, which was likely to hamper the use of ponton bridges, an attack upon 
Kharkov from the rear did not appear to be possible. The only feasible course, therefore, was to roll up the enemy flank from the south, 34\%

The drive on Kharkov began on 6 March and continued to gain ground as the Fourth Panzer Army and the SS Panzer Corps pushed ahead in a northerly direction to the west of the Donets, strongly supported by bomber and ground-attack units of the I and IV Air Corps. 35 Soviet units which were concentrating or moving out of Kharkov and villages farther to the north were heavily bombed and strafed by the Luftwaffe, and, when the Russians began their disorderly retreat on 10 March in the area between Kharkov and Belgorod, Fourth Air Fleet squadrons destroyed many troop and vehicle columns. 36

It soon became clear that the Russians were beginning to evacuate Kharkov, whereupon the Fourth Panzer Army and Army Force Kempf, supported by Fourth Air Fleet planes, harassed the withdrawing columns. On 11 March I Air Corps units were committed to strike retreating Russian forces in the Volchansk-Belgorod area. 37 Luftwaffe airmen also carried out highly concentrated attacks to interdict Soviet retrograde movements toward the Donets River, 38

Tactical support air units attacked Belgorod, where the headquarters of the Soviet II Guards Tank Corps was situated, and made a decisive contribution to the defensive successes achieved by the Division Gross Deutschland on 14 March. On that day the forces of the Fourth Panzer Army drove toward Kharkov and the SS Panzer Corps took the city. 39

The Soviets then threw strong armored forces against the Wehrmacht from the Belgorod area. These units were countered by powerful thrusts from the Division Gross Deutschland and the SS Panzer Corps pushing ahead from the south. In these encounters the support of the I Air Corps was a vital factor in favor of German units, which soon pierced Belgorod's defenses and took possession of the area. $40 \mathrm{~W}$ ith the seizure of this point the first phase of the German offensive came to a close. The arrival of the muddy season precluded any immediate extension of the front. $t$

*See $\overline{\text { Map }}$ No. 3.

fSee figures 1 and 2. For a more detailed account of the capture of Kharkov and Belgorod in March 1943, see U.S. Department of the Army, OCMH, German Defense Tactics Against Kussian Breakthroughs, DA Pam. No, 20-233, EUCOM, Historical Division, October 1951, pp. 3-8. 


\section{THIS PAGE DECLASSIFIED IAW E012958}

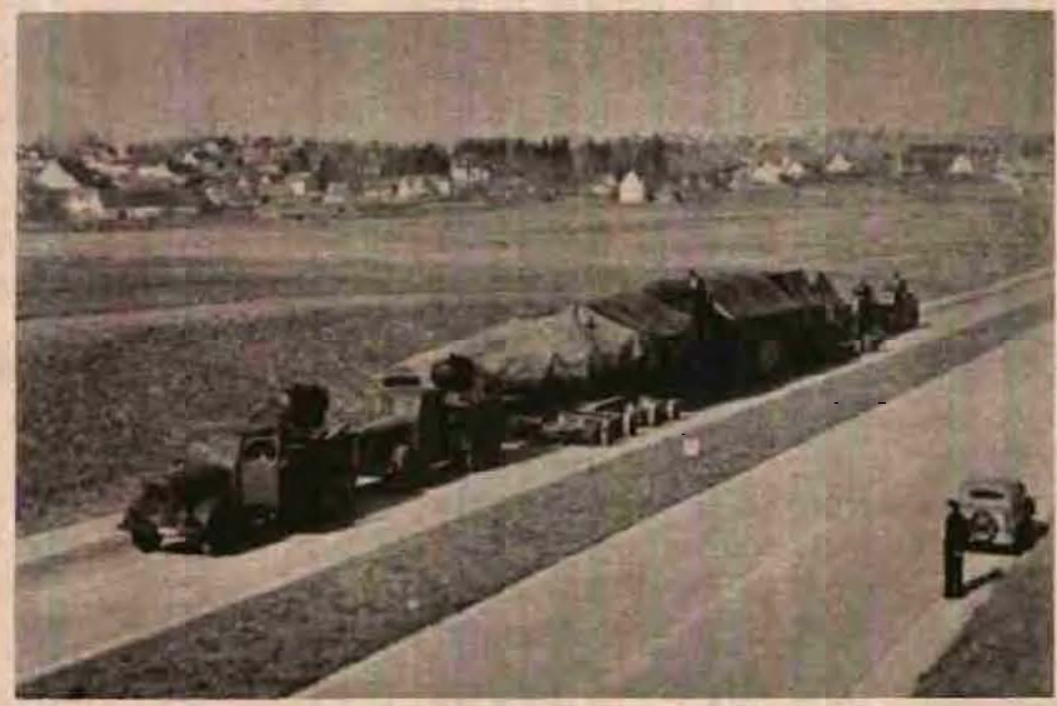

Figure 1

Small German submarine, bound for the Black Sea, on the Autobahn between Dresden and Ingolstadt on the Danube, 1943

(Courtesy of the United States Naval Institute and

Fregattenkapitaen a. D. Friedrich Popp)

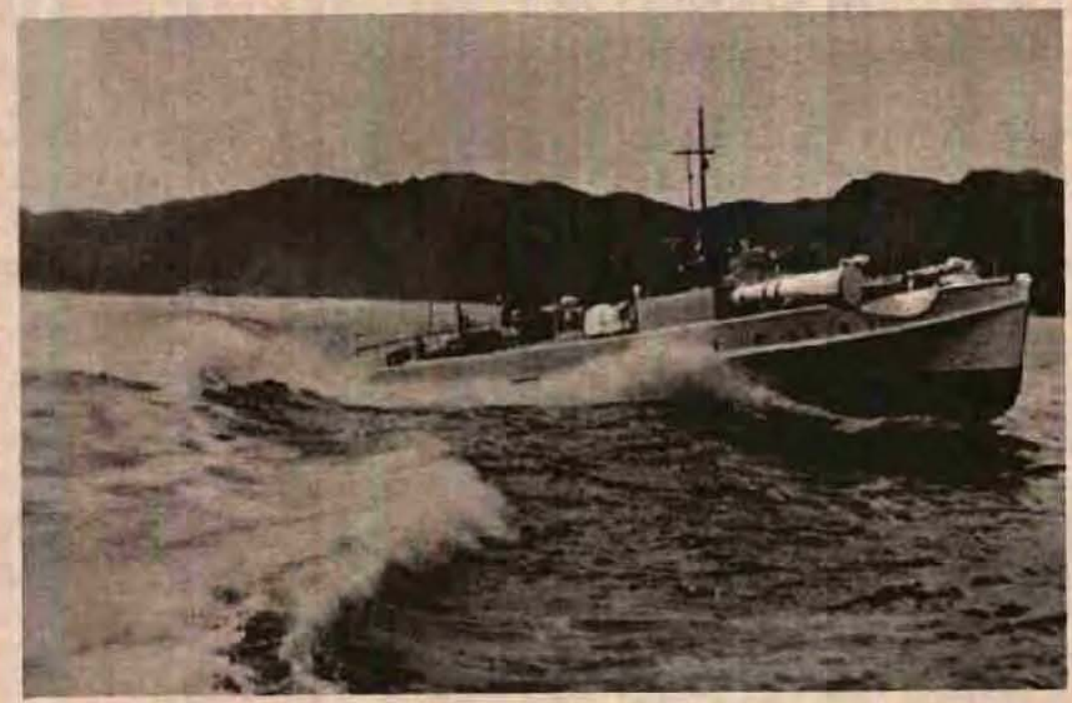

Figure 2

German motor-torpedo boat (S-Boot)

operating in the Black Sea 
The successful outcome of the foregoing operations, all of which had heavy air support, clearly indicates the decisive character of Luitwaffe assistance to the German ground forces both on the offense and defense. The crowning achievement of the Wehrmacht's counteroffensive was the recapture of Kharkov, an accomplishment which was effected essentially by a well coordinated and highly concentrated assault by both air and ground forces, All available aircraft, including long-range bombers, were thrown into the battle and employed in a tactical role for close support in consonance with the classical German pattern. 41

The development of areas of main effort through the closest possible concentration of all available forces, a flexible command, and extremely close cooperation between participating air and ground commands were the principal ingredients for success in all Luftwaffe operations.

Von Richthofen's Fourth Air Fleet was thrown into the battle for Kharkov as one integrated whole, with the participating commands supporting each other, thereby insuring the availability of maximum air power at the crucial point. The main factors behind Richthofen's successes were extreme flexibility, good coordination, and concentration, the latter being secured through the creation of ad hoc battle groups to give air support to spearhead units of the ground forces (SS Division "Das Reich"t) which led the assault on the city. "Massive concentration, "drastic concentration," "concentration of all forces to the highest degree," were phrases which appeared again and again in Fourth Air Fleet battle orders.

Another factor which played a role in these operations was Richthofen's reservation of the right to switch his area of main effort from one air corps to another as the tactical situation required. Both the I and the IV Air Corps were instructed to make sure that their tactical units could be immediately brought to bear in other operational sectors. 42

Once the objectives of the winter counter offensive had been realized with the capture of Kharkov and Belgorod, the ceaseless air operations in support of the Army, which had become the German trump card in so many critical situations in the winter, were no longer required. The Luftwaffe was therefore free to carry out its real mission of operating against hostile air forces and sources of enemy military power, including communications routes and feeder lines.

*Editor ${ }^{1} \mathrm{~s}$ Note: 2nd SS Panzer Division. 
In addition to a number of successful strikes against industrial targets in Saratov and Kamyshin, and shipping (including mine-laying operations) on the Volga as far as Astrakhan and the Caspian Sea, continuous and increasingly heavy attacks were carried out against Soviet railroad trains, rail installations, bridges, and depots. 43 As early as February 1943 German bomber units had been increasingly employed in attacks against Soviet rail lines and railroad installations in efforts to prevent or seriously hamper the forward movement of Russian supplies and replacements and the regrouping of forces in areas of critical concern.

Once the city of Kharkov had fallen, air operations against Soviet rail systems gained considerably in importance, especially since the early thaw had turned all of the main and secondary roads into quagmires and virtually precluded motor transportation. The few special railroad interdiction squadrons, which were organized within the various air wings in 1942, were committed regularly against Soviet rail traffic, while larger rail installations and junctions were attacked by powerful concentrations of bombers. 44

Soviet air activities had also increased apace since the beginning of the year, for which reason the Fourth Air Fleet now became more immediately concerned with Russian flying units and attacked their bases whenever possible. These expanded operations of the Fourth Air Fleet against rail and air installations continued until the end of June 1943. Although the attacks achieved considerable local success, their overall effect was felt only gradually. There was no escaping the fact that the forces available to the Luftwaffe in Combat Zone South were too weak to completely destroy or interrupt for any considerable period enemy rail traffic, road traffic, or air activity. 45 


\author{
Chapter 2 \\ LUFTWAFFE OPERATIONS IN DEFENSE \\ OF THE KUBAN BRIDGEHEAD
}

The planned evacuation of the Caucasus began at the turn of the year 1943. It was designed to extricate the First Panzer Army, which had advanced as far as the Groznyy area in its drive along the Terek River, and the Seventeenth Army, which was engaged in heavy fighting on a wide frontage extending from Novorossiysk to Mt. Elbrus. A broad flanking maneuver by the Red Army threatened both of these armies with envelopment. 1* The withdrawal of the First Panzer Army from phase line to phase line, protected in the north and northeast against close Soviet pursuit, until it was able to cross the Don River above and below Rostov to its new positions on the left flank of Army Group Don, has already been discussed. 2

The Seventeenth Army synchronized its movements with those of the First Panzer Army and tried to withdraw farther to the south, with Novorossiysk as the pivotal point for its right flank. This army, under the command of Generaloberst Richard Ruoff, continued its deliberate retrograde movements, harassed by pursuing Red Army units. Frequently the Seventeenth Army was forced to establish interim defensive positions from which it fought numerous delaying actions, until it finally reached the area of the lower Kuban River. There it established a bridgehead which was intended as its final defense line.

By about the end of April 1943 the bulk of the Seventeenth Army's forces were situated in their new positions behind a front extending in a line from Novorossiysk-Krimsk-Kiyevskoye-Krasnyy Oktyabr-east of Temryuk. 3 During the army's slow withdrawal and the establishment of its positions on the Kuban, the Fourth Air Fleet directed the VIII Air Corps to give it all possible support. 4 The corps committed its divebomber forces immediately in advance of the German front, repeatedly attacking Soviet troop concentrations and assemblies, while its bomber and reconnaissance units harassed Soviet traffic leading to the front.

*See Map No. 1. 
Weak fighter units available to the VIII Air Corps carried out frequent attacks upon Soviet air forces and air installations, downing a considerable number of enemy planes. Owing to Russian numerical superiority, however, they were unable to prevent many Soviet groundattack squadrons from inflicting a substantial amount of damage on German installations and losses on German troop units.

Supported by the massed fire of heavy artillery batteries, including naval guns, and strong air forces, the Red Army succeeded on the night of 3 February in crossing the three-mile-wide Bay of Novorossiysk and in securing a foothold at a number of points. These sites were then immediately reinforced by the arrival of additional Soviet units. 5 The German V Air Corps began its counterattacks at once, cleaning out two of the small enemy beachheads and driving the Russians back across the sea. Yet the Wehrmacht's counterattack against the Soviet beachhead south of Novorossiysk, after initial progress, failed, with heavy losses of life. Here the Russians not only were able to maintain their position by fierce fighting but to expand and reinforce it.

The VIII Air Corps repeatedly attacked this beachhead and seaborne traffic leading to it, placing main emphasis upon air strikes in the Novorossiysk area, where this support helped to relieve the pressures on German ground troops. * During this time Soviet fighters began to appear in ever greater numbers, frequently attacking German airfields and ports, especially in and around Kerch, in strong attempts to isolate the German Seventeenth Army from its logistical bases. 6

Along the rest of the Caucasus front the withdrawal of the Seventeenth Army to the inner perimeter of the Kuban bridgehead, the so-called Gotenkopf Stellung (Goth's Head Position), proceeded generally according to plan. VIII Air Corps units gave valuable support to the Seventeenth Army by attacking Soviet spearheads again and again with good results. On the ground, the young soldiers of the 615th Field Training Regiment rendered particularly conspicuous service, especially during the heavy fighting on 12 February, during which time they were effectively supported by weak, but determined, German air units. 7

Meanwhile, specially assigned railroad interdiction aircraft flew repeated missions against Soviet rail routes, junctions, and bridges in the

*Attacks were made by $\mathrm{Ju}-88$ and $\mathrm{He}-111$ units, including (for the first time in this area) the lst Group, 3rd Dive-Bomber Wing. 
Caucasus, achieving good results, thereby delaying and reducing in amount the reinforcements and supplies of all types which were brought up to enemy organizations on the front. 8

Daily Soviet air attacks increased steadily against Seventeenth Army positions, the few airfields located within the Kuban bridgehead, the important supply port of Taman, and ships crossing the Straits of Kerch. 9 In spite of good results achieved by German fighters stationed in the area, Luftwaffe forces here were numerically too weak to protect the entire Kuban bridgehead against hostile air action. German fighter and interceptor units were also hampered severely by the soggy condition of the airfields. 10 For these reasons it was especially important to provide increased air defense by the greater use of flak artillery batteries with the ground forces as well as with reax installations.

On 7 February 1943 the newly organized 9th Flak Division* (Generalmajor Wolfgang Pickert) was placed in command of all antiaircraft artillery forces in the Seventeenth Army area and assigned the mission of assuming, in collaboration with two weak fighter and one dive-bomber groups, responsibility for the air defense of the field of battle, and especially the supply ports of Kerch, Taman, Anapa, and Temryuk, shipping in the Straits of Kerch, and airfields situated within the bridgehead area and in the Crimea. 11 Initial emphasis was to be on the Straits of Kerch. 12

Realizing the inadequacy of the flak forces available for the accomplishment of this mission, the Supreme Command initiated on 10 February a special rail movement which, within 10 to 12 days, advanced 23 heavy, 6 light flak, and 8 searchlight batteries to the Crimea. These were immediately assigned to the 9th Flak Division.

At the beginning of March, before reinforcements arrived at the front, the dispositions of flak artillery forces were approximately as follows:

4 heavy $(8.8 \mathrm{~cm})$ and 2 light batteries in the vicinity of Novorossiysk

*Editor's Note: This was formed around the remnant of the Divisional Staff, the only part of the oxiginal 9th Flak Division which did not fall within the Stalingrad pocket. At the time the unit surrendered on 31 January 1943, it had destroyed 460 aircraft and 820 tanks, most of them after being surrounded (22 November 1942). 
2 heavy $(8.8 \mathrm{~cm})$ and 2 light batteries at the port and airfield of Anapa

2 heavy and 2 light batteries in the area west of Krimsk

3 light batteries in the Kurchanskaya area

3 light batteries at the Kuban bridgehead at Temryuk

4 heavy and 3 light batteries at the port and airfield of Taman

2 heavy batteries, for action against seaborne targets and incidental hostile air action, situated at the southern entrance to the Straits of Kerch

In addition to the units mentioned above, relatively strong antiaircraft forces had to be assigned to airfields and naval bases in the Crimea. At the beginning of March, 47 heavy, 31 light, and 8 searchlight batteries were temporarily available, Of these, 16 heavy batteries were withdrawn after just a few weeks, as soon as the overall situation had settled down a bit, and before these batteries could be transported across the Kuban River to reinforce the antiaircraft defenses in the bridgehead.

Flak units in the southern sector of Combat Zone South were controlled by three regimental headquarters, one situated in the Kuban bridgehead, one at Kerch, and one in the western Crimea. 13 The available flak forces were then initially assigned to the main combat sectors of the bridgehead area, Novorossiysk, Krimsk, and Kurchanskaya, with special concentration around the Straits of Kerch and Taman. Sufficient antiaircraft artillery was also laid around the decisively important Kuban River bridge at Temryuk. *

Since most of the heavy batteries deployed around the Straits had a seaward field of fire, there was a chance to bring under relatively heavy fire Soviet naval units which were expected to attack at any time. Because of the possibility of night attacks by sea, a number of searchlight batteries were stationed in the area of the Straits, and heavy flak batteries there were issued ample quantities of star shells. 14

In this connection it seems appropriate to discuss briefly the naval situation in the Black Sea. In numerical strength and in types of vessels available, the Soviet Black Sea Fleet was vastly superior to the weak German Navy units, which consisted primarily of S-boats (Schnellboote)

*See Map No. 6. This was an important link in the German supply line. 
or motor torpedo boats. * The light Rumanian naval forces could scarcely provide any material increase in German naval strength in the area. Yet, with the exception of a few attacks by motor-torpedo boats, the Soviet Black Sea Fleet remained surprisingly inactive. Its units remained in ports between Tuapse and Batum, under the protection of Russian fighter forces. 15 This remarkable passiveness can possibly be explained by an intention of the Soviet Command to save its Black Sea Fleet in case it was needed for decisive action later in the war. $f$ All Soviet naval units and installations, including ships at sea and in port, were kept under constant surveillance by reconnaissance units of the VII Air Corpstt and the German Black Sea Naval Air Command.

Besides supporting army operations, the VIII Air Corps also had the concurrent mission of moving large quantities of supplies by air to the Seventeenth Army. 16 Nonessential equipment, troops required for other assignments, and considerable numbers of casualties were daily flown out of the bridgehead area, while large amounts of ammunition, weapons, fuel,

*Editor ${ }^{\prime} s$ Note: S-boats and several other types of small naval vessels, including small submarines, were floated up the Elbe River from Hamburg to Dresden, taken thence by road (Autobahn) past Bayreuth and Nuernberg, a distance of 280 miles, to Ingolstadt. They were then floated down the Danube to Linz, where they were completely fitted out, then driven under their own power downstream to the Black Sea. The trip from the North Sea to Linz took eight days and cost 34,000 Reichsmarks. A total of 428 ships, 16 of which were S-boats and 6 of which were submarines, were brought in this way to the Black Sea, a total of 40,000 tons. See Jan Mayen, Alarm-Schnellboote! (Alarm! Motor-Torpedo Boats), Oldenburg/ Hamburg: Gerhard Stalling Verlag, 1961, pp, 140-144. See also Friedrich Popp, "Overland Transport of German Ships during World War II, " United States Naval Institute Proceedings, Vol. 81, No, 1, January 1955. See also figures 1,2 , and 3 .

fEditor's Note: The Soviet Black Sea Fleet included the battleship Sebastopol, 6 cruisers, 21 destroyers and torpedo boats, 30 sea-going submarines, 50 motor-torpedo boats and gunboats, as well as a number of auxiliary craft. See Friedrich Popp, "Overland Transport of German Ships during World War II, "United States Naval -Institute Proceedings, Vol. 81, No. 1, January 1955.

$+\not$ Later by the I Air Corps. See figure 4. 


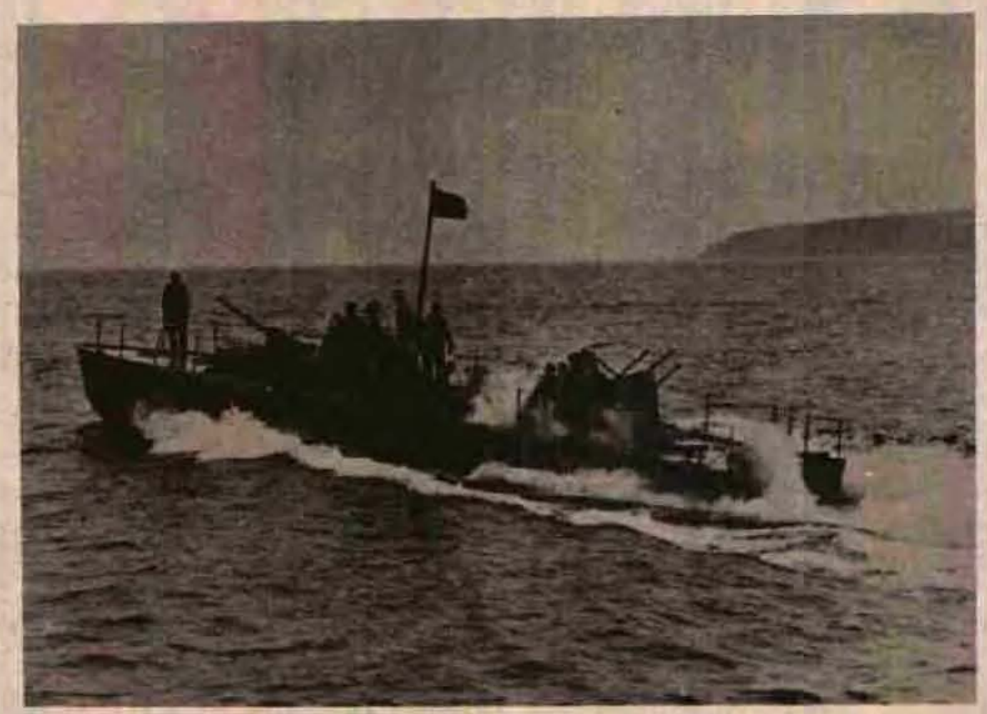

Figure 3

German storm boat, armed with quad-20-mm. guns, in the Black Sea

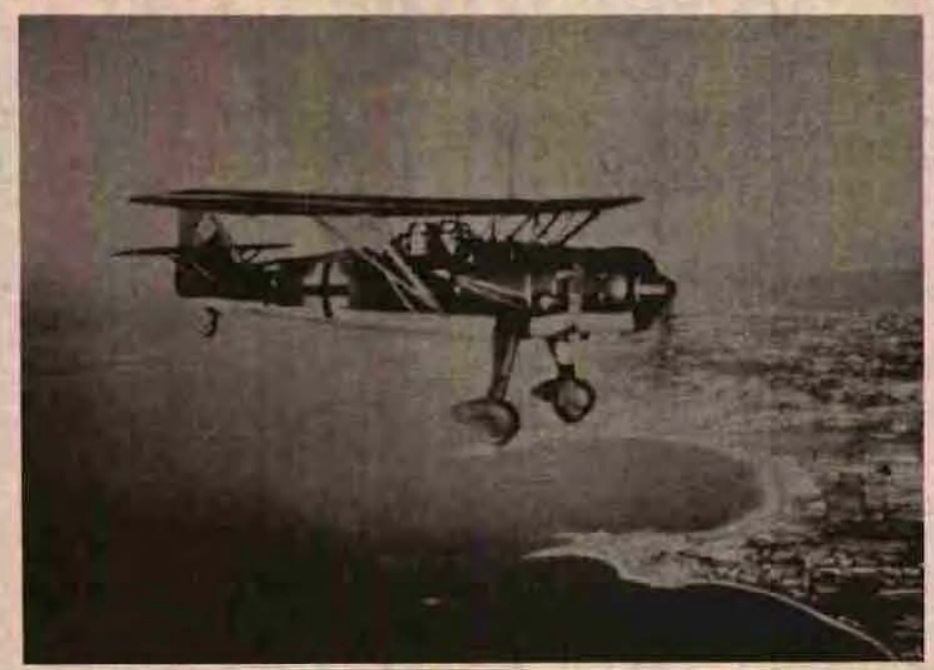

Figure 4

Luftwaffe Hs-126 reconnaissance plane over the Kerch area 
and replacements were flown in. 17* On 9 March 1943 seaplanes were also utilized for the first time in this airlift operation. 18

Russian units continued to exert heavy pressure against the Seventeenth Army as it withdrew to the GotenkopI position, and German units frequently had to fight their way through Soviet forces which were already in their rear. By constantly changing the areas of attack, the Russians endeavored to split and breach the well-integrated German front, which was gradually falling back. This retrograde movement was further complicated by the spring mud season which commenced as early as midFebruary. With effective support from units of the VIII Air Corps, the Seventeenth Army succeeded, despite the adverse conditions, in halting and repelling all Soviet attacks, sealing off or cleaning out each penetration as it occurred. These problems were especially acute on the army's flanks, since the Russians constantly tried to outflank or envelop Wehrmacht units operating there. Such an attempt was made by the Soviet Fifty-eighth Army in the vicinity of Shedogub, an effort which was frustrated by German forces (4th Mountain Division and 13th Panzer Division) after four days of bitter fighting. 19

On the right flank the Soviet bridgehead south of Novorossiysk was a constant and particularly critical danger point. Soviet units could only supply and reinforce themselves in this area by transporting men and other required needs across the Bay of Novorossiysk. Since daylight traffic across the bay was exposed to the observation and artillery fire of German forces and to the frequent attacks by units of the VIII Air Corps, the Russians restricted their supply movements to the nights, which were still long in February and March.

Because of problems in transporting supplies caused by the soggy condition of the roads and by drift ice in the Staits of Kerch, German Army artillery units were forced to economize in the use of ammunition. Therefore the bridgehead and supply traffic could not be kept under constant harassing fire. In this situation the Luftwaffe's flak artillery was a welcome and most effective support for the ground forces.

*On 28 February 1943 the Commander in Chief of Army Group "A, " Field Marshal Ewald von Kleist, extended his tharks to the VIII Air Corps for having transported 50,000 soldiers out of the bridgehead. See Einsatz der taftflotte 4 im Kampfraum Sued der Ostiront, I. I. I943- I2. 9 . I943 (Employment of the Fourth Air Fleet in Combat Zone South of the Eastern Front, 1 January - 12 September 1943), G/vI/4d, Karls Document Collection. See figures 5 and 6 . 


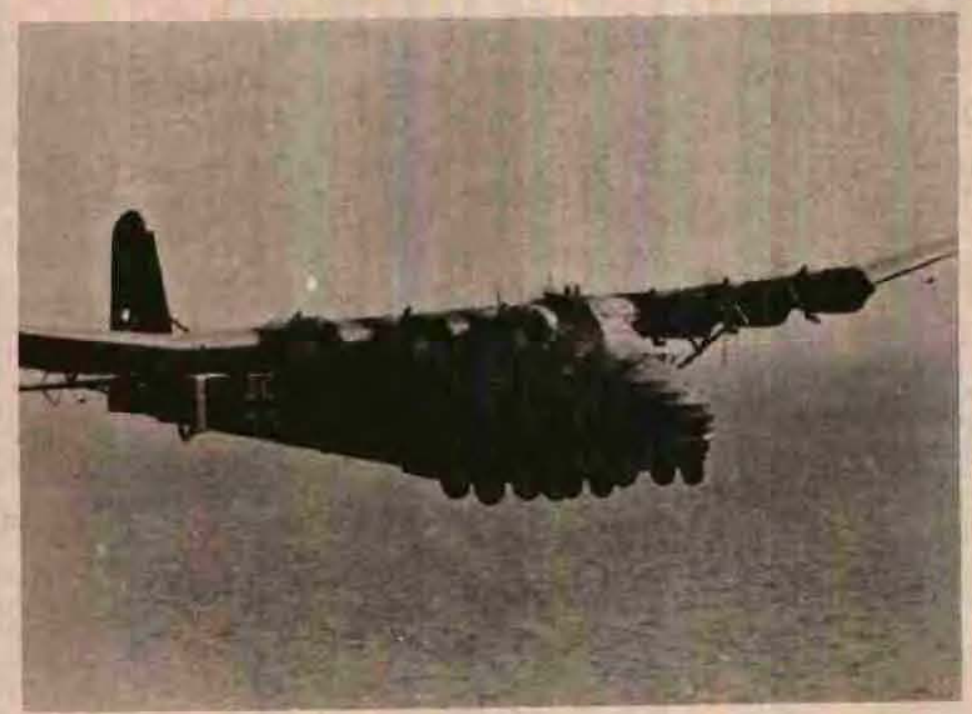

Figure 5

The Me-323 "Gigant" brings in supplies

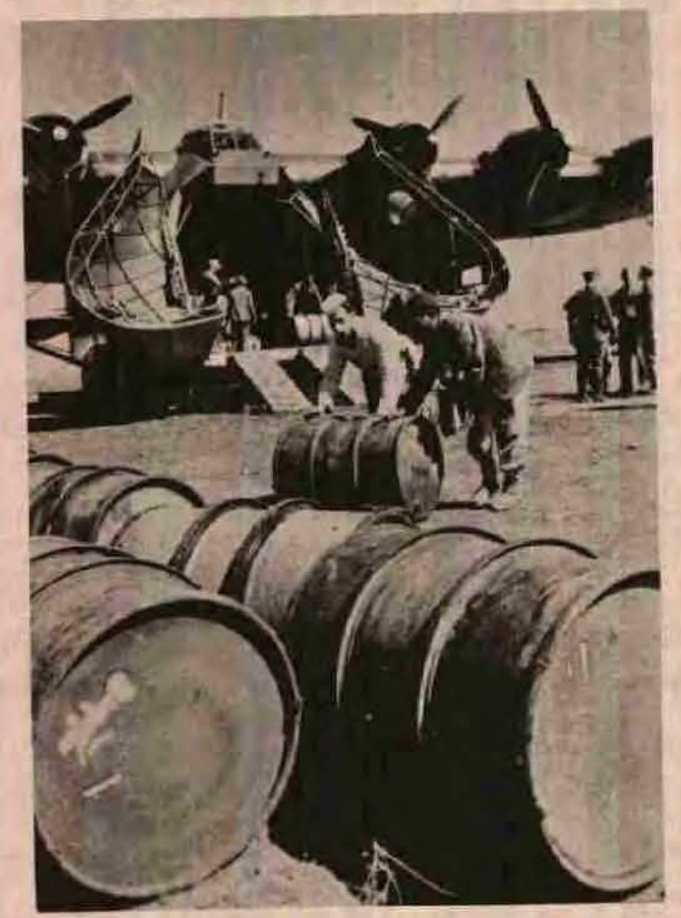

Figure 6

Unloading aviation fuel from an $\mathrm{Me}-323$ "Gigant" 
Individual $8,8-\mathrm{cm}$ guns and a number of searchlights were moved into position in the port of Novorossiysk to prevent the Russians from capturing the port and expanding their beachhead through an amphibious assault. These guns repelled Soviet sorties which were being made by small naval craft. *

Another important requirement in the area was to keep enemy traffic across the bay under observed fire as completely as possible. Illuminating devices necessary for this purpose were lacking in the initial stages, and with parachute flares it was possible to light up the bay for only a short period of time. During most of the night, therefore, an $8.8-\mathrm{cm}$ gun, especially assigned for the purpose, fired hundreds of parachute flares and star shells over the bay at irregular intervals. By the illumination afforded by these flares and star shells Army artillery was able to bring most of the enemy sea traffic under fire.

Parachute flares used in the area were a special supply item issued for coastal defense. Shells could be set to release a parachute flare at any given altitude, and the released flare then lighted up the target area with considerable brightness for several minutes. Flak units were the only organizations that had adequate supplies of these flare shells, with which they were able to offer a signal contribution to Army defensive operations. $20 t$

A marked increase in shipping was noted along the Soviet controlled shores of the Black Sea, and it was assumed that this had some bearing upon the enemy beachhead at Novorossiysk. The VIII Air Corps therefore directed its units to attack this shipping in collaboration with German Navy units. Air reconnaissance forces of the corps detected an enemy tanker on the night of 12 March 1943 and directed several German motor-torpedo boats (S-boote) $f f$ to the target. On the following morning air reconnaissance located the tanker aflame outside the port of Tuapse. 21

Luftwaffe units also carried out repeated aerial mining operations against the port of Gelendzhik, from which the Russians were shipping supplies. Other enemy ports were bombarded by individual Luftwaffe aircraft.

*See figure 7 .

tSee figure 8 .

thSee figure 2 . 


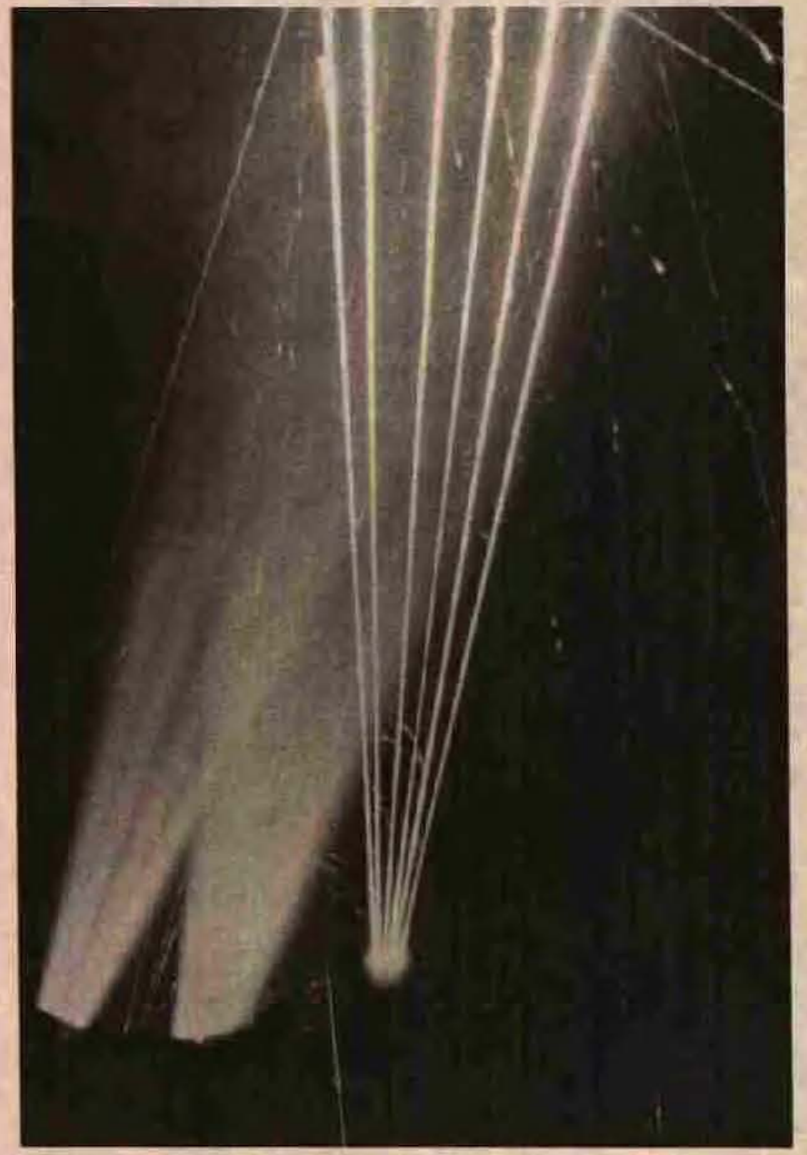

Figure 7

Searchlights and light flak guns

in air defense action near

the Straits of Kerch 


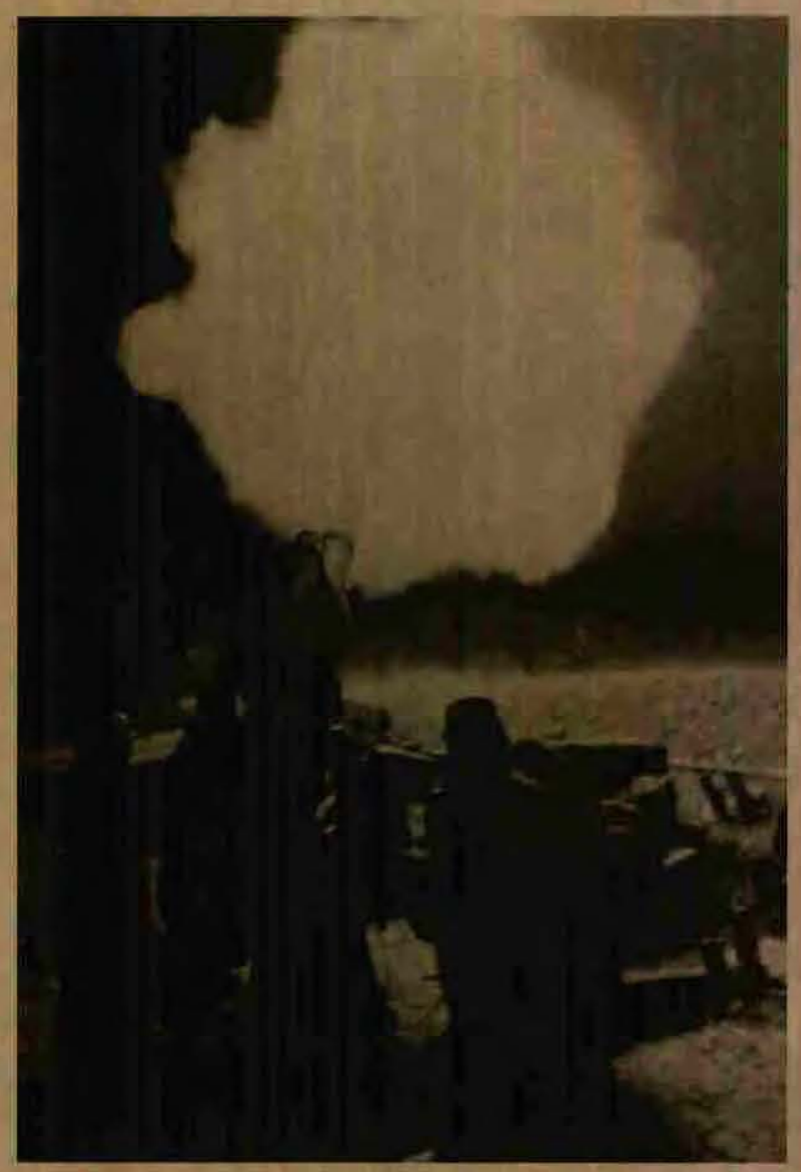

Figure 8

Heavy (8. 8-cm.) flak gun firing at night in the Kuban area 
The last airlift of German personnel and equipment into the Kuban bridgehead was flown on $30 \mathrm{March}$, and on the next day a change was made in the Luftwaffe command in the Kuban-Crimean area. VIII Air Corps Headquarters was withdrawn and transferred to the northern flank of the Fourth Air Fleet to support Army Force Kempf. 22\% I Air Corps assumed command of the German air forces supporting the Kuban bridgehead. This corps, under the command of Generalleutnant Guenther Korten, 23 was established at Simferopol in the Crimea, with an advanced command post at Kerch. The mission of units assigned to th is headquarters remained primarily one of direct combat support of German ground forces in action against Soviet troop concentrations, particularly concentrations of armor, against enemy occupied settlements in the vicinity of the front, and against targets such as enemy artillery batteries and troop movements.

Strong air forces were still committed to attack Soviet reinforcement movements, regrouping of enemy forces, and supply traffic moving over road and rail routes to the front opposite the Kuban bridgehead. Owing to lively Soviet air activity, German fighter units had a multitude of targets and achieved good results in shooting down Russian aircraft.

On 14 April 1943 powerful Soviet forces achieved a breakthrough at Krimsk. The I Air Corps then supported the Seventeenth Army in its defensive battles by making repeated concentrated air attacks at the points of penetration. 24 Fighters and ground-attack aircraft shot down 56 Soviet airplanes, while antitank air units destroyed 8 enemy tanks.

On 17 April Operation NEPT UN was launched, an operation by the V Corps (4th Mountain, and $73 \mathrm{rd}$ and 125th Infantry Divisions) to eliminate the enemy beachhead south of Novorossiysk, which was such a constant source of anxiety to the German Command. Powerful air forces, comprised of 2 fighter groups (reinforced by Rumanian and Slovakian squadrons), 2 dive-bomber groups, and a bomber wing of 2 groups, concentrated under the I Air Corps, flew repeated missions in support of the ground attack. They rained a merciless hail of bombs on the beachhead area and on the batteries along the eastern shores of the bay, but in spite of concentrated air and artillery fire, the attacking German troops achieved only slight penetrations into the tenaciously defended Soviet positions. The rugged terrain of the Caucasus foothills, covered by numerous small woods,

*Editor's Note: Named after its commander, General der Panzertruppe Franz Werner Kempf. This unit was known as Army Force Lanz until its redesignation 22 February 1943 as Army Force Kempf. On 15 August 1943 it was again redesignated, this time as the Eighth Army. 
provided excellent cover and protection for the Russian defenders and reduced the effectiveness of German bombing attacks. Even the heaviest concentrations of air power and artillery produced rather poor results, and the infantry again had to bear the brunt of the battle, seizing bunkers one at a time at great cost. 25

On 17 April, German assault forces attacking the enemy beachhead south of Novorossiysk encountered strong Soviet positions in the racks, organized in great depth like a fortress. German infantrymen made slow progress against these powerful bastions in spite of heavy support by the Luftwaffe.

Dive-bomber units under the leadership of Col. Dr. Ernst Kupfer were directed to attack and destroy enemy pockets of resistance, observation posts, and troop concentrations, and to make repeated attacks to break Soviet defenses in the line of advance. The first mission flown by this unit was badly hampered by unfavorable weather, yet its bombs were dropped on target, scoring one direct hit on a Soviet battery and hits upon other adjacent infantry and artillery positions. Two light explosions and two heavy explosions --the latter were probably ammunition or fuel dumps going up--were observed somewhat after the main bomb bursts. Kupfer's flyers also destroyed 10 horse-drawn vehicles, and strafed field positions and troop concentrations with good results.

During these operations Soviet antiaircraft fire of all calibers was noticeably heavier in the morning than in the afternoon, and Red fighter-interceptors appeared at irregular intervals over the front. German losses in these engagements consisted of three damaged $\mathrm{Ju}-87 \mathrm{I}^{\mathrm{s}} \mathrm{s}$ which crash landed on their airfield, four Ju-87's so badly damaged that they were out of action for a brief period of time, and four $\mathrm{Ju}-87^{\prime} \mathrm{s}$ which sus tained some damage by Soviet antiaircraft fire. A total of $494 \mathrm{Ju}-87 \mathrm{I}_{\mathrm{s}}$ took part in the operation. 26

On the following day, $511 \mathrm{Ju}-87 \mathrm{I}^{\mathrm{s}} \mathrm{s}$ went into action in attack waves of 25 aircraft each, the first units talking off at 0445 and the last unit landing at 1830 hours. Only a few enemy fighters were encountered and the Soviet antiaircraft fire was relatively light, mostly by light and medium guns. These missions were flown in support of Army Force Wetzel, * which was then trying to capture the enemy beachhead. In the first mission, one group of Ju-87's attacked the Soviet-held southern part of the city of

*Editor's Note: Named for its commander, Generalleutnant Willhelm Wetzel, who later commanded the V Infantry Corps. 
Novorossiysk, while four other groups attacked alternate targets farther to the south, including the railroad bend, the old fort, and the mud baths.*

The heavy cloud cover broke up only a few times during the day, and then for brief moments only. Nevertheless, hits were scored by the Luftwaffe upon the Jaegerhoehe (Hunter's Summit), Russenriegel (Russian Obstacle), and artillery positions, one gun being definitely destroyed. 27

A force of $294 \mathrm{Ju}-87^{\prime} \mathrm{s}$, operating in 16 group-size missions, carried out air operations on 19 April in support of the Seventeenth Army's fight for the beachhead. Good results were achieved against infantry and artillery positions and troop concentrations, smothering the Tafelberg and Zuckerhat heights with well-placed bombs. Strong enemy antiaircraft and fighter forces attempted to halt the air attacks. 28

The German Army launched another attack to seize the Soviet beachhead on 20 April, but made very slow progress. Some small gains were achieved in the direction of the Jaegerhoehe, where the Russians had established their fortress-like positions and offered tenacious resistance. Wehrmacht losses were so heavy that the attack bogged down and, on the following day, had to be called off. During these battles the Russians committed very strong air forces against German ground forces and against Luftwaffe bombers. While the German Air Force employed all available combat aircraft in the area and succeeded in scoring a number of direct hits on infantry and artillery positions, and upon the observation post on the Tafelberg, the advance of the friendly ground troops was almost negligible. 29

In the afternoon, the 1st Group, 2nd Dive-Bomber Wing and 2nd Group, 77th Dive-Bomber Wing successfully attacked a high-level Soviet headquarters in target area 9 (near the beachhead), and at dusk all of the available bomber forces attacked jetties and other landing sites in the beachhead. During the night, $165 \mathrm{Ju}-87^{\prime}$ 's of the 1 st and $3 \mathrm{rd}$ Groups of the 2nd and 3rd Dive-Bomber Wings attacked landing points in the Novorossiysk beachhead area, diving upon the objectives from an altitude of 10,000 feet. For unknown reasons, one of the Ju-87's crashed in flames west of Kayarovo just before landing. 30

Because the Russians had begun to use large masses of airpower over the beachhead area, sizeable air battles developed. In the course of

*Editor ${ }^{\top}$ s Note: This area had been a spa of some repute. 
these, units of the 1 Air Corps shot down 91 enemy planes on 20 April, while German fighters operating over the right flank of the Seventeenth Army shot down 56 aircraft. 31

In the latter part of April the Russians staged a new breakthrough attack against the XXXXIV Corps at Krimsk. Units of the I Air Corps immediately went into action against the Soviet forces which had broken through. Bombers, dive-bombers, and ground-attack aircraft dropped their bombs on enemy-held wooded areas, enemy tanks, artillery batteries, and villages, and effectively strafed every hostile troop concentration and troop movement in the battle area. German fighters found "rich grazing" against the strong Soviet fighter and ground-attack forces, suffering only light losses of their own. The numerically inferior German fighter force shot down 63 Soviet planes on 29 April, 32 on 30 April, 35 on 3 May, and 24 on 7 May. 32

On 29 April the Red Army again launched a major attack against the eastern sector of the XXXXIV Corps area, with main effort against the 97 th Light Infantry Division. Following an artillery and mortar preparation during which 20,000 rounds were fired against the German main line of resistance at Krimsk alone, and using air support on a hitherto unprecedented scale in this area, nine Soviet rifle divisions and three tank brigades hurled themselves at the German positions. The German Army repelled this initial assault with only slight losses of its own, but at a heavy cost to the enemy.

On the next day the Soviet command shifted its main effort to the 9 th Division, and later extended these attacks to the 101 st Light Infantry Division. Again German forces halted the enemy onslaught, and immediately cleaned out the small areas of hostile penetration. Soviet losses were exceptionally heavy in this battle. Immediately in front of and within the positions of the 57 th Infantry Regiment the Wehrmacht counted 1,200 enemy dead after two days of fighting. Losses on the German side were also considerable. The Russians enjoyed air superiority in the area for a number of days, despite Luftwaffe efforts, and, because of this fact, Soviet forces were able to neutralize much of the German artillery. 33

On 26 May, after a few days of comparative quiet, Red Army units again tried to break through the XXXXIV Corps front. This battle raged on until 7 June. In the course of the fighting, Soviet objectives were the commanding heights known as Hills $121.4,114.1$, and 95. 0. Russian forces applied heavy pressures against the badly weakened Wehrmacht forces on the line, especially against the 9th Division, and the 97 th and 10lst Light Infantry Divisions. 
The Soviet infantry attack was preceded by heavy night air attacks and artillery barrages. On the first day the Russians achieved a deep penetration in the 101 st Light Infantry Division sector, north of Moldavanskoye, 34 This dangerous situation was alleviated by the 97 th and 101st Light Divisions, which launched a determined counterattack, supported by the Luftwaffe, and succeeded in narrowing down the enemy penetration. A gain and again Red Army tanks broke through the German lines, but in each case the infantry following the armored drive became separated from the tanks, which were then rapidly destroyed behind the German front. Some tanks were able to withdraw in time to ayoid being knocked out, but these were few in number.

In this battle the German air forces successfully contested Soviet air superiority and, by exemplary cooperation with German ground forces, were able to break up numerous enemy attacks in the assembly stage and to force Soviet artillery to move to new positions. The Red A rmy employed 13 rifle divisions, 3 rifle brigades, and 6 large tank units in this engagement, but was forced to break off the attack after losing 100 tanks and 350 aircraft. 35

Luftwaffe bombers repeatedly attacked Soviet airfields by day and night, achieving excellent results and materially relieving the pressures on German ground forces. Because of the success of these German air attacks the Soviet air activity slackened off markedly from time to time.

On the southern shore of the Sea of Azov, northeast of Temryuk, the Red Army tried to land troops from specially constructed flat-bottomed boats and landing craft, but these efforts were frustrated almost at once by the outstanding work of newly committed German antitank air units. * Because of German air power these Russian attempts were extremely costly. 36

Col. Hans-Ulrich Rudel, $\downarrow$ who had been so successful in antitank air operations, assumed command of the experimental antitank air units which were dispatched on their first combat assignment to the Kuban bridgehead area. 37 The Antitank Air Command was equipped with Ju-88 aircraft, some of which were armed with a single $75-\mathrm{mm}$. gun mounted under the pilot's cockpit, and with Ju-87's (dive-bombers), such as flown by Colonel

*During the winter of 1942-43 tests were carried out with Ju-87 antitank aircraft at Rechlin (Mecklenburg) in the Zone of the Interior, and at Bryansk, in the Communications Zone of the Eastern Theater of Operations. A total of 43 tests had been made by the spring of 1943 .

tEditor's Note: A veteran of 2,530 combat missions, he was Germany's most highly decorated flyer. See biographical section in the back of this study. 
Rudel, outfitted with a 37 -mm, antitank gun mounted under each wing. Special ammunition, consisting of regular ammunition with tungstenhardened cores, was designed for these weapons. These projectiles were reported to have been able to penetrate any thickness of armor plate then in use and to explode after piercing the armor.

The Ju-87 Stuka, a slow-flying aircraft, was highly vulnerable to modern fighter attacks. Because of this it had been used since 1941 chiefly in the East, and in other theaters only when good fighter cover could be provided or under unusual circumstances. The $\mathrm{Ju}-87 \mathrm{G}$, a special development of the "D" series, was even more susceptible to enemy air defense forces, since the installation of the two $37-\mathrm{mm}$, guns lowered its speed substantially. Maneuverability and general flying characteristics were hampered by these innovations and by the removal of the Stuka's dive brakes. Fire power was the quality most needed in the East at this time, and this factor was given priority over consideration $\bar{s}$ of handling and speed.*

The Ju-88 P experiments with the large-caliber $(75-\mathrm{mm}$.) $f$ gun were soon discontinued because the tests showed no real prospects for success. Experiments indicated that operations with the $\mathrm{Ju}-87 \mathrm{G}$ would also result in heavy losses. Most of Rudel's pilots were therefore quite skeptical about going into combat with these planes, although Rudel was favorably impressed with the new innovations. Test flights flown by him proved that the $37-\mathrm{mm}$. guns could be fired with accuracy to within 8 to 12 inches of a given target. He thus concluded that tanks could be easily destroyed if the Ju-87 could be flown close enough to the targets.

Rudel's unit memorized the silhouette patterns and characteristics of the various types of Soviet tanks, including the precise location of their most vulnerable parts, the engines, fuel tanks, and ammunition chambers. This had to be done because it was not enough to hit a tank; it had to be struck precisely at a point where the shell would strike inflammable or explosive material, thereby destroying the vehicle. After 14 days of final testing the Air Ministry ordered the unit to proceed immediately to the Crimea, where Soviet forces were exerting heavy pressures, and where opportunities for further experiments were infinitely greater.

*Editor's Note: The Ju-87 D had a top speed of about 250 miles per hour, and had rather poor landing characteristics.

Fditor's Note: The 75-mm. gun was the standard PAK 40 (antitank gun), 
It was too dangerous to fly low with these planes and to fire at an altitude of only a few feet over areas which had well-established fronts and strong local ground defenses. The Luftwaffe knew that losses in such situations would be greater than the results which could thereby be achieved. If the $\mathrm{Ju}-87 \mathrm{G}$ could be used at all, it could only be in areas where the fronts were relatively fluid and the ground situation was constantly changing.

Capt. Hans-Karl Stepp, Commander of the Experimental Command in Rechlin, Mecklenburg, remained in Bryansk for a time, while Colonel Rudel took off with all operational aircraft by way of Konotop and Nikolayev to Kerch. Rudel's old wing was then flying bombing missions at Krimsk in the Kuban bridgehead area, where fierce fighting was in progress. From old comrades it was ascertained that Soviet tanks, in case of achieving a breakthrough, never operated more than 1,000 to 1,600 yards from the old main line of resistance. This meant that they would have to be attacked while they were still under the protection of permanently installed, and therefore very strong, antiaircraft batteries.

The defensive fire power of the Red Army was highly concentrated in the small battle area, where it had moved in just about everything that it had from remote areas near the Caspian Sea and the oil centers. These forces came to the scene of combat by way of Mozdok-Pyatigorsk-Armavir and Krasnodar. *

A few days after Rudel, the famous "Panzerknacker" (tank cracker), arrived on the Eastern Front he began operations with his unit south of Krimsk. Soviet tanks had penetrated the outer German defenses in that area and were within 900 yards of the main line of resistance. The antitank air unit immediately flew in to see what it could do to counter this attack. Rudel's plane was hit by antiaircraft fire while he was still over his own lines, and other aircraft of the unit fared no better. To make matters worse the Russians also countered with an early model of the Spitfire, which performed well in combat against the Luftwaffe aircraft. This was the first time Rudel had noted these fighters on the Eastern Front.

The results of the first test operations were none too rosy. Wherever members of the antitank unit appeared, other flyers were quick to

*See Maps Nos. 1, 6, and 7 . 
paint gloomy pictures and to prophesy a short life for them. It was clear that bombs would have to be brought along to combat the Soviet ground defenses, but bombs, in addition to antitank guns, would be too heavy for the aircraft. Also, with large-caliber guns mounted on its wings, the $\mathrm{Ju}-87$ could not dive, since the strain on the airfoils would have been too great. Therefore, the most practical solution was to operate under the escort of dive-bombers,

A new offensive operation by the Russians brought the big change for the unit. Northwest of Temryuk Red forces tried to outflank the Kuban River front. Elements of two Soviet divisions began to move through the lagoon region by boat to bring about the collapse of the German Kuban lines. Only a few friendly outposts and small strongpoints were located in this swamp and lagoon area. Their defensive capabilities were naturally limited and by no means adequate to cope with the new Soviet operation.

Reconnaissance uncovered large concentrations of boats in the ports of Yeysk and Akhtarsk, which were immediately attacked. Yet, the targets were so small and the boats so numerous that these attacks alone could not possibly deter the Russians. The boats then commenced moving in masses through the lagoons, traveling approximately 30 miles. As they worked their way through the lagoons and the narrow connecting channels, they came closer and closer to Temryuk, behind the Kuban front, and penetrated far into the German rear. Russian troops usually rested among the tall reeds or on the islands, and when thus hidden were very hard to spot,- But, to make any progress, they had to come out into open water, and every day the Luftwaffe was over the area from morning until night searching for boats. As Rudel describes these movements:

Ivan [the Russians] were coming in the most primitive of boats; seldom did one see a motor boat. They conveyed themselves across in the little boats, 5 to 7 men at a time; up to 20 men were crowded into the larger ones. Of course we didn't make use of our special armor-piercing ammunition here, because a high penetration power was not needed, but rather a good bursting effect for strikes upon wood, which was the surest way to shatter the boats. Normal flak ammunition, with a suitable detonator, proved to be the best. Everything that traveled on top of the water was lost. The boat losses for Ivan must have been very heavy. In a few days I alone destroyed 70 boats with my plane. 
The [Soviet] ground defenses increased slowly but proved to be no obstacle to us. First Lieutenant Ruffer, an excellent gunner in an $\mathrm{Hs}_{\mathrm{s}} 129$ of one of the other antitank squadrons, fell out of his plane and landed like Robinson Crusoe on an island in the midst of the lagoons. He had luck; a German patrol rescued him unharmed. 38

German forces carried out a successful attack on 3 and 4 July, sealing off the penetrations made by Soviet forces on the northern flank of the Seventeenth Army northeast of Temryuk. This timely attack saved the XXXXIX Mountain Corps from envelopment. Wehrmacht units, operating in exceptionally difficult terrain, defeated Red Army forces in the lagoon area, capturing 428 prisoners, 207 deserters, and 92 boats. Luftwaffe flying units destroyed another 427 boats, while flak batteries gave highly effective support to German ground forces by repelling Soviet troops attempting to outflank their positions in the jungle-like lagoon area. 39

The Russians became increasingly active in the air and no longer restricted their field of action to the near front areas, but began to attack by day and night targets deep in the German rear. Their main objectives were the bridge at Temryuk, the port and supply installations at Taman and Kerch, traffic across the Straits of Kerch, and the air and naval bases located on the Crimean Peninsula. 40

In the early months of 1943 the I Air Corps was comprised of the following units:

1 strategic reconnaissance squadron ( $\mathrm{Ju}-88$ ) at Sarabuz

1 tactical reconnais sance squadron (Hs-126 and FW-189) at Kerch

1 fighter group (Me-109) at Anapa

1 night fighter squadron at Bayerovo

1 Rumanian dive-bomber group $(\mathrm{Ju}-88)$ at Bayerovo

A number of training planes used for night harassing raids, later incorporated into night ground-attack squadrons

Besides these, the I Air Corps controlled Air Command Black Sea, which had:

2 squadrons (Bv-138) at Konstanza

1 squadron $(\mathrm{Bv}-138)$ at Sevastopol

3 Rumanian fighter squadrons at Yevpatoriya and Odessa

1 air-sea rescue squadron at Orta-Eli 41 
A night fighter squadron was moved in to reinforce the night air defense forces and, with the aid of available searchlight batteries, helped to organize an illuminated night fighter defense in the Kerch area, 42 Despite the lack of efficient communications and other facilities which are normally available in the Zone of the Interior, the effectiveness oi the night defense system was improved by the addition of night fighterinterceptors and heavy flak batteries.

The heavy batteries opened fire the moment antiaircraft searchlights spotted a plane, and continued firing until the alerted night fighters (guided by radio from their base to the target) signaled that they were ready to attack. * The flak batteries then immediately ceased fire and the fighters attacked. By close cooperation it was possible to sharply reduce the time interval between the batteries' cease fire order and the opening of the night fighter attack to less than a minute. Using these methods, by mid-July of 1943 the Luftwaffe had shot down 59 Soviet aircraft operating at night in the area. Twenty of these planes were destroyed by night fighter forces and the rest by heavy $(8.8-\mathrm{cm})$ flak batteries $\downarrow$ Because of the sound air defense operations, Russian airmen began to avoid the Kerch area in the night raids.

Night bombing and strafing attacks in the bridgehead area by Soviet planes proved to be quite unpleasant, especially for German supply traffic, which was particularly heavy at night. These harassing raids were a well-known feature of service in the Eastern Theater of Operations, and were particularly frequent in the Kuban area. Here, too, an improvisation brought about a considerable reduction in the number of enemy nuisance raids. Since the illumination provided by the two searchlight battalions in the Kerch areas was indispensable to air defense operations, the smaller $(60-\mathrm{cm})$ searchlights assigned to certain flak batteries were placed in positions in the Temryuk area, and distributed in such a way that a new night fighter area was established. If Once these defenses were set up the Soviets also avoided the Temryuk area,

A point deserving special mention is the successful establishment by the 129th Air Signal Battalion of the 9th Flak Division of a broad and

\footnotetext{
*See figure 7 .

fEditor's Note: Part of the aircraft reported here were shot down in the Temryuk area.

ffTwo Russian aircraft were brought down by the confusion caused by the searchlights. Apparently more inexperienced pilots were being used here than elsewhere.
} 
intricate wire and radio communications network, so necessary for coordinated night operations using searchlight, flak, and night fighter units. This battalion proved itself thoroughly and exemplified the best traditions of the Air Signal Service by setting up the network in surprisingly short time and in maintaining it well, despite a critical shortage of personnel, terrain difficulties, and enemy action. 43

From 7 February (the date on which the 9th Flak Division assumed

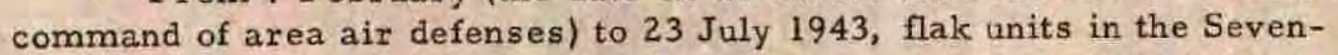
teenth Army area shot down 224 Soviet aircraft during daylight hours and 39 at night. In addition to these obvious and tangible results, flak units must also be accorded high ratings for repelling the enemy and for shielding troop units on the field of battle, 44

In August a fierce defensive battle again developed in the bloodsoaked area west of Krimsk, and on the 7 th the storm broke again in the eastern sector of the line held by the V and XXXXIV Corps. After an exceptionally heavy artillery preparation, the Soviet forces, using air support which exceeded anything hitherto experienced in the area, attacked the 9 th Infantry and 97 th Light Infantry Divisions. Because of the massive air support, German defenders were virtually paralyzed for hours, 45

Luftwaffe fighters went into action and were able to effectively restrict the activity of Soviet ground-attack planes, enabling the two German divisions to reestablish an integrated defense line by employing their last available reserves and those at corps level. 46

Under the impact of their exceptionally heavy losses, the Russians broke off their attack on 12 August 1943. Excellent cooperation and mutual support by all arms of the Army and Luftwaffe had made it possible to hold the line. Although the Red Army launched other attacks along the Seventeenth Army front during the period which followed, Soviet efforts in the first 10 days of August were the last major actions fought in the Kuban bridgehead. Early in September the German High Command decided to abandon the bridgehead and withdrew the Seventeenth Army across the Straits of Kerch to positions on the Crimean Peninsula. $47 \%$

While this evacuation movement was getting under way, the Russians made another attempt, preceded by a powerful artillery barrage, to seize the city and port of Novorossiysk. German Army troops immediately counterattacked and repulsed them with heavy losses. While

*See Map No. 6. 


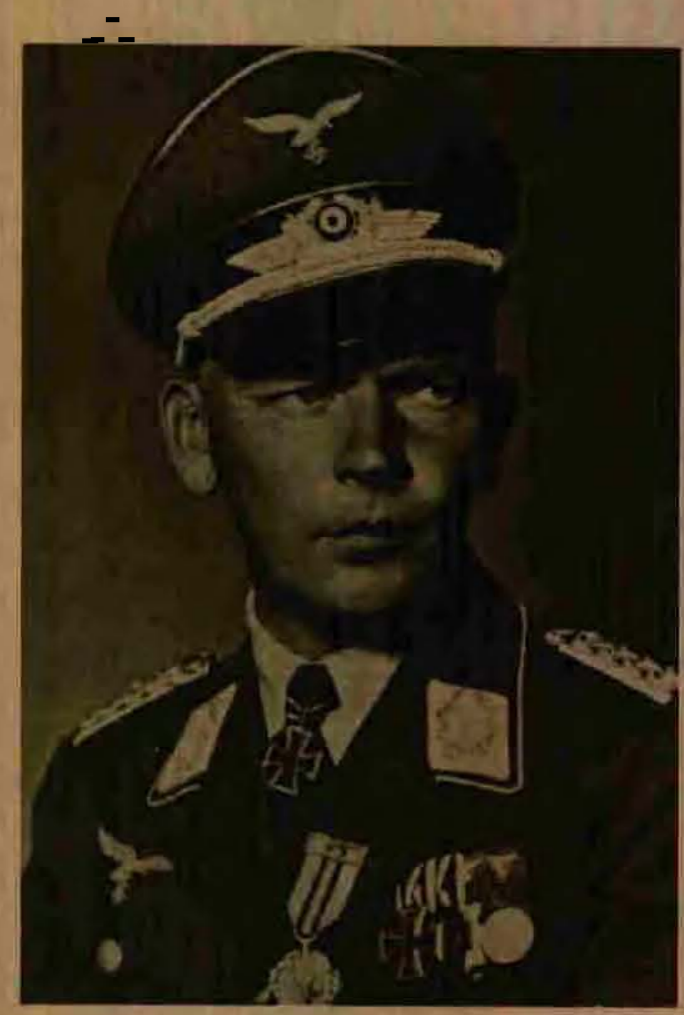

Figure 9

Generaloberst Wolfram Freiherr von Richthofen, Commander in Chief, Fourth Air Fleet 


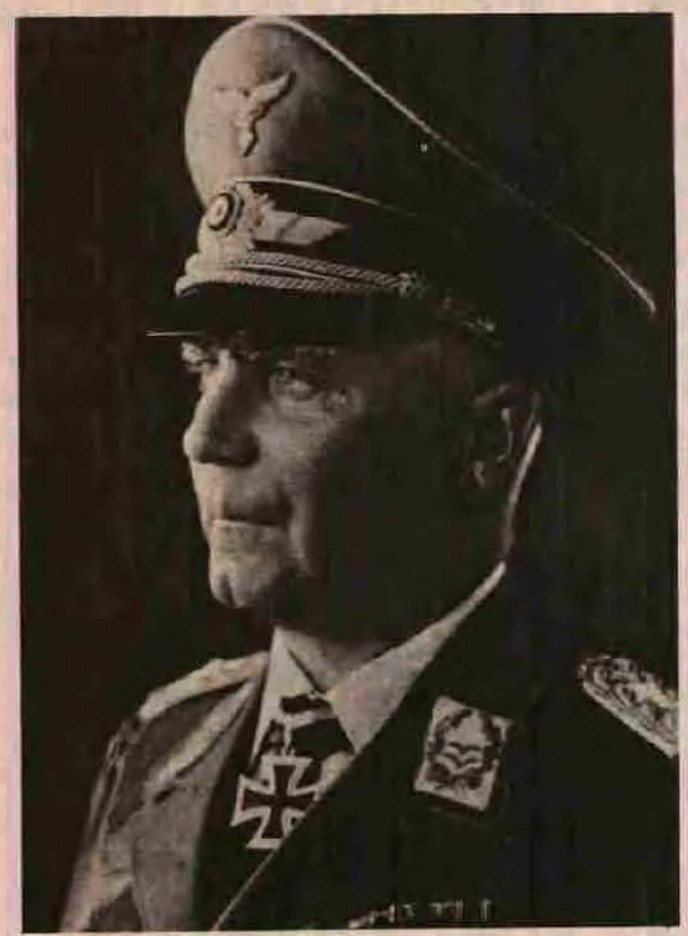

Figure 10

General der Flieger Otto Dessloch, Commander, Luftwaffe Group Caucausus 
ground forces were engaged in bitter combat, fighter-bomber units of the I Air Corps supported the action by destroying Soviet landing craft and troop concentrations in the Russian beachhead. 48

The evacuation of the Kuban bridgehead commenced on the night of 14 September, all troop units retiring according to plan by short movements. Because the 9 th Flak Division had deployed very strong forces along both shores of the Straits of Kerch, and because fighters of the I Air Corps maintained a continuous cover over these retrograde movements and all crossing points, the initial stages of the withdrawal proceeded without enemy interference. * Luftwaffe airmen carried out their tasks very well, considering that the Russians enjoyed a great numerical advantage on the ground and in the air in this sector. It was thus inevitable that some Soviet ground-attack aircraft would get through to accomplish their missions. 49 These planes repeatedly attacked German rear guard positions, but were invariably turned away by the concentrated fire of light and heavy flak batteries, which had been deployed there between February and April during the battle for the Kuban bridgehead. At that time 21 light and 16 heavy batteries had been posted in the area, doubling the number of flak units within the bridgehead. Of this number, 13 light and 4 heavy batteries were fully mobile, while the remainder had to rely upon flak artillery transport batteries for transportation. The latter had to be evacuated during the early stages of the withdrawal. This naturally necessitated a sizeable increase in flak forces in the Straits area, where it was believed that the Russians would soon step up the number and intensity of their attacks.

To further improve the protection for evacuating units, two light flak batteries were mounted on Siebel Ferriest to escort traffic across the Straits in the last four days of the withdrawal. Furthermore, all batteries received orders in this closing period not to withhold their fire while awaiting the approach of hostile aircraft, but to open fire at extreme range. Light batteries normally waited until the attacking planes were within optimum range, but in this instance what was urgently

*See figures 4,9 , and 10 .

tEditor's Note: Siebel Ferries were motor-driven firing platforms, invented by Dr. Fritz Siebel in an effort to combat Soviet transport shipping on Lake Ladoga and also in the Black Sea area. They were extremely slow and unmaneuverable, and were not particularly effective when operating by themselves. See figure 11 . See also Generalleutnant a. D. Hermann Plocher, The German Air Force versus Russia, 1942, USAF Historical Studies No. 154, Maxwell AFB, Alabama: USAF Historical Division, ASI, 1966. 


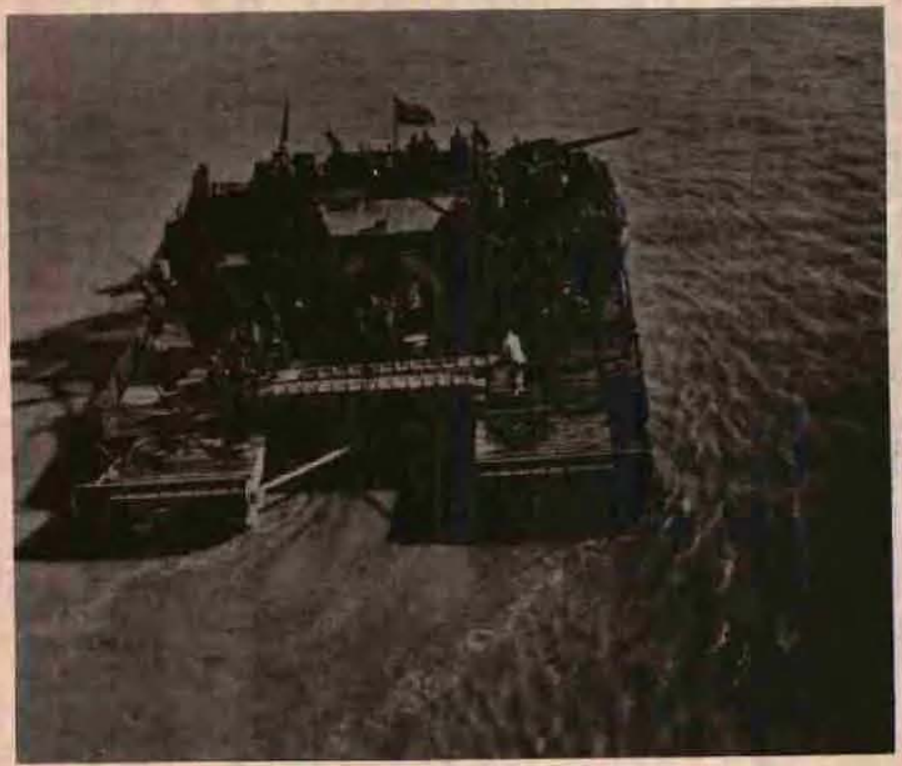

Figure 11

A Luftwaffe expedient, a floating flak platform, the Siebel Ferry 
required was early firing to repel enemy aircraft, which were coming in in substantial numbers. This, of course, meant a heavy consumption of ammunition. These means made it possible to ward off decisive enemy air interference during the crossing movement and to reduce greatly the effectiveness of Soviet attacks against the temporary, but unavoidable, accumulations of vehicles and materiel at the crossing points. The virtual abseñce of trees or bushes on the eastern shore of the Straits made matters particularly difficult for the troops, who had no choice but to disperse as well as they could and to dig in to avoid hostile air action. An increased commitment of fighter forces by the Luftwaffe greatly reduced the danger of Soviet air attacks during the entire operation.

On the night of 9 October 1943 the last flak unit, the 81 st Light Flak Battalion, together with the rear guard troops of the Seventeenth Army, crossed the Straits at Ilyich. This ended the evacuation of the Kuban bridgehead after many months of exceedingly heavy fighting.

Flying units under the command of the VIII (and later the I) Air Corps, flak batteries of the Army and the Air Force under the command of the 9 th Flak Division, and numerous air signal units played a most decisive role in the successful defense of the bridgehead area.

The unusually heavy losses suffered by the Russians, including 1, 045 tanks and 2, 280 aircraft, were due in no small measure to action by Luftwaffe units, all of which were badly outnumbered by their Soviet opponents. 50 


\section{Chapter 3 \\ LUFTWAFFE COMMAND EAST IN COMBAT ZONE CENTER OF THE EASTERN THEATER OF OPERATIONS}

\section{Operations, January - July 1943, Prior to Operation ZITADELLE}

In early January 1943 severe defensive battles raged along the front of the left wing of Army Group Center, in particular along the fronts of the Third Panzer Army and the Ninth Army from the vicinity of Velikiye Luki to Rzhev. Soviet armies pushed the German lines back in the direction of Vitebsk, and again threatened to break through the pocket which had been created in the offensive late in 1942. * Yet, despite these pressures, Army Group Center was able to hold its lines fairly well and to prevent a serious penetration. 1 The Ninth Army stood exposed in a salient projecting to the east of Rzhev, a matter of concern to the German Command. Despite this problem, only one important point was lost in the entire sector during this period, and that was the small fortress of Velikiye Luki, which fell after a heroic defense on 17 January. $t$

During these operations Luftwaffe Command East had concentrated its forces and provided day and night combat and logistical support (including glider and air-drop missions) for the Velikiye Luki garrison. But, these efforts, which had to be made in the most adverse weather and in the face of heavy small and large arms fire, turned out to be in vain, since the German forces were too weak to hold off the vastly superior Russian forces. A few of the defenders succeeded in breaking out of the envelopment on the night of 15 January and in fighting their way through to the Wehrmacht relief forces. 2 ft

After the fall of Velikiye Luki the front in this area remained relatively quiet for some time, although it was obvious that the Russians would try to capitalize on their advantageous position as soon as they had amassed a sufficient predominancy in men and arms and as soon as the concentration movements had been completed. In order to delay the enemy's offensive

*See p. 5.

tSee figure 12 and Maps Nos. 2, 3, and 7.

ftSee Maps Nos, 2 and 3. Despite heavy air support, the relief forces were unable to reach the Velikiye Luki fortress. 


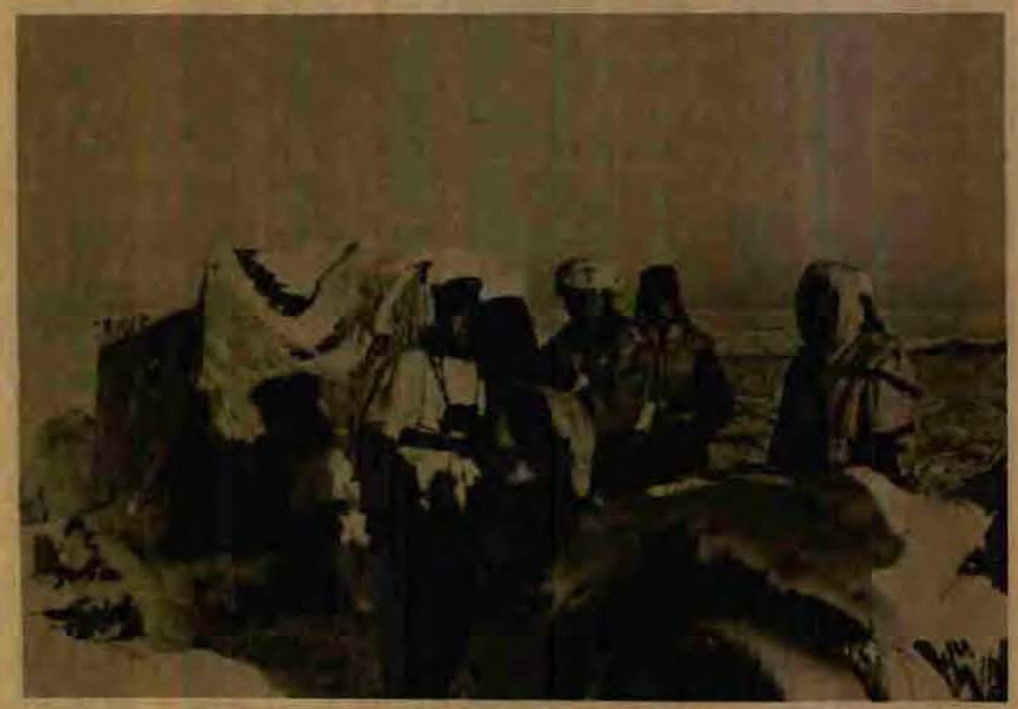

Figure 12

Generaloberst Robert Ritter von Greim visiting

a flak unit near Velikiye Luki

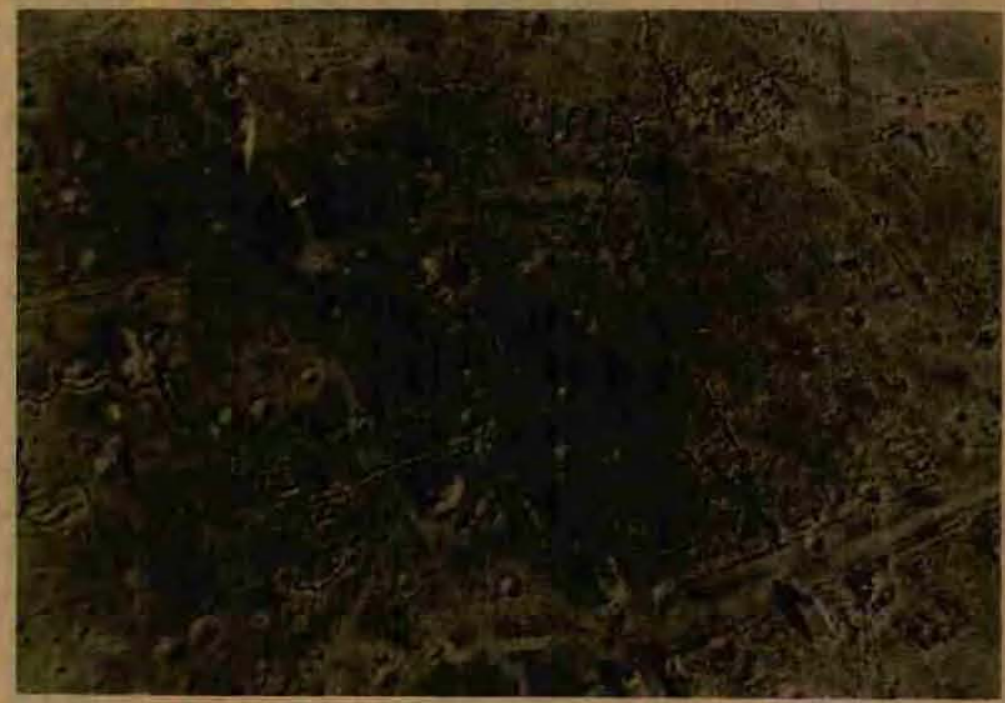

Figure 13

Pock-marked battlefield on the edge of the city of Rzhev 
plans and to prevent build-ups of men and materiel near the front areas, Luftwaffe units concentrated from mid-January on upon interdicting Soviet road and rail supply traffic. In the course of these actions German flyers caused heavy damage to the rail supply depots at Kalinin, Toropets, and Velikopolye.

In case of a full resumption of the attack by the Red Army, the German Command had no experienced troops available to use as reserves, and the only forces at hand which could strengthen the defenses in any way were some rather weak Luftwaffe units, which were scraped together wherever they could be spared. In the face of this situation, Generaloberst Kurt Zeitzler finally succeeded in wringing from Hitler approval to retire the front line in the area between Yukhnov and Rzhev to a line extending approximately from Spas Demensk to Bely. *

Thorough and systematic preparations were made for the retirement. All Army and Luftwaffe supply depots were evacuated to the rear; all permanent installations, particularly airfields, railroads, and bridges, were completely demolished; and the proposed new main line of resistance was reinforced with strong positions. This movement, known as Operation BUEFFEL (Buffalo), commenced at Rzhev on 26 February. About half of the Fourth and Ninth Armies, their southern flank anchored at Spas Demensk, fell back in good order from phase line to phase line into the new positions.

The withdrawal to a new position meant that German air units in the near front areas also had to move back, this time to Smolensk-North. Ground service installations from advanced bases were evacuated by truck between 25 and 28 February, and on 1 March Luftwaffe demolition teams blasted the billets and shelters, buildings which were so familiar to many German servicemen in the area and had served the Luftwaffe so well. $f$ The last crews flew out of Dugino on $2 \mathrm{March}$. Reconnaissance units moved back to their old quarters in an abandoned cloister at Smolensk and were soon back in a normal routine.

During this time, despite frequent spells of very bad weather, tactical and strategic reconnaissance units furnished highly valuable information on the activities of the enemy, in many cases discovering assembling and concentration movements. Early in February the 4th Strategic

WSee figure 13.

tSee figures 14 and 15 . 


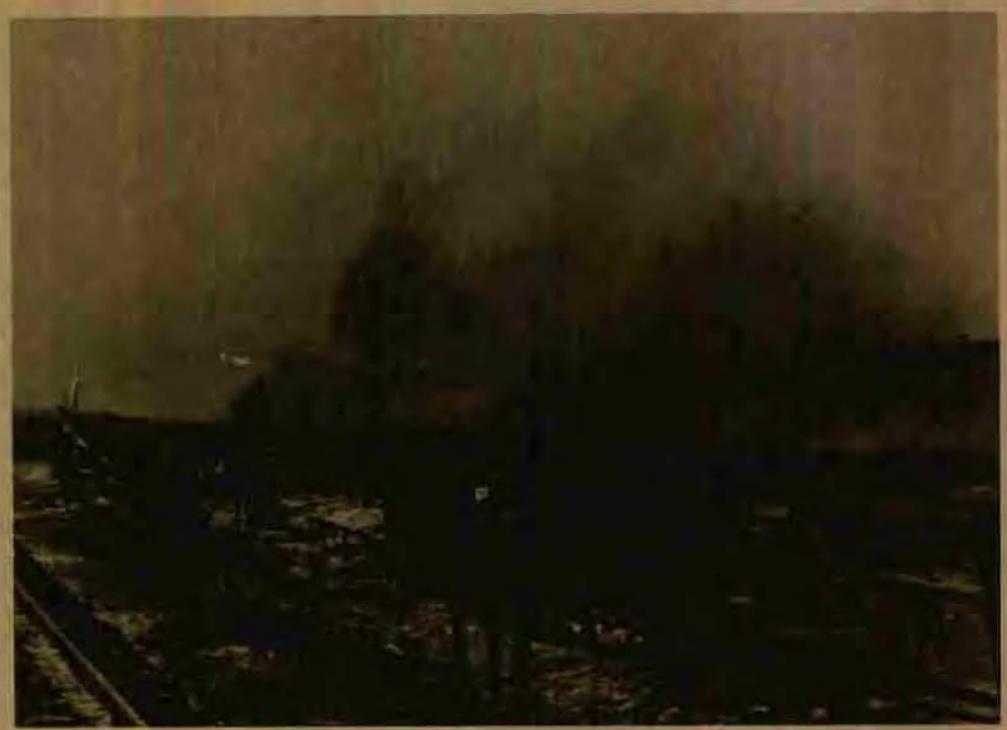

Figure 14

The railroad station at Vyazma being systematically leveled by Luftwaffe demolitions men, 19 March 1943

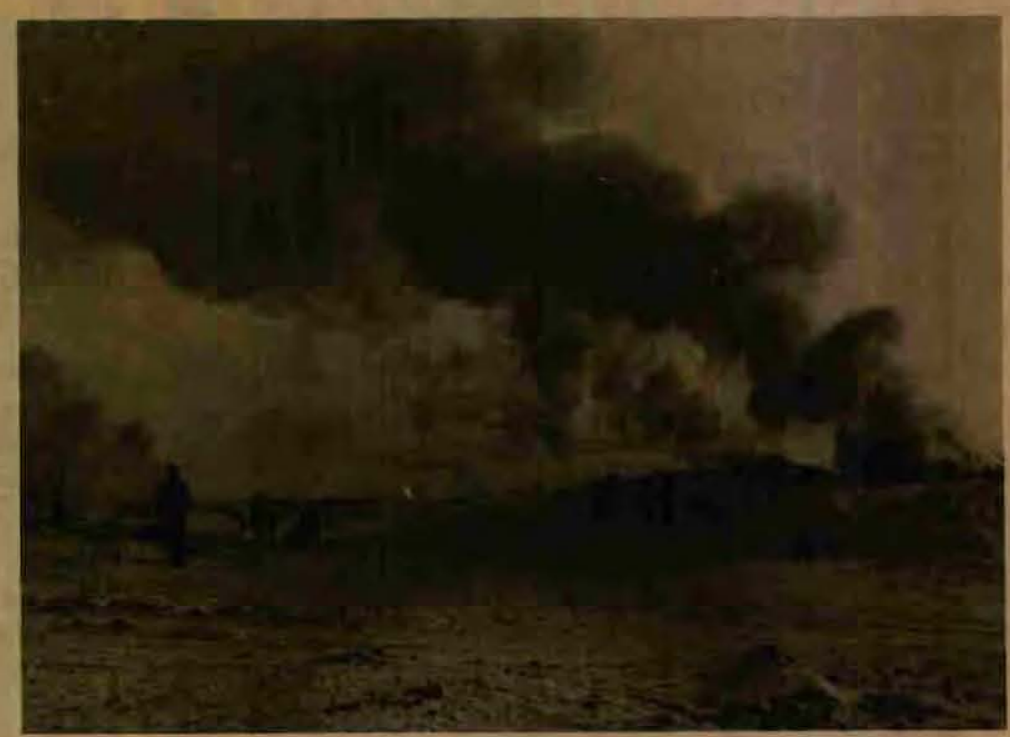

Figure 15

Dugino airfield (south of $\mathrm{R}$ zhev) being demolished by Luftwaffe demolitions teams, March 1943 
Reconnaissance Squadron* of the 14th Reconnaissance Wing detected large Soviet troop movements between Kalinin and Ostashkov and kept surveillance over this area, even during the worst weather conditions. On 10 February the weather was so bad and the cloud ceiling so low that reconnaissance could be carried out only at extremely low altitudes, with the result that one aircraft was shot down. On the following day the clouds parted and the 4th Squadron identified Soviet columns, including tank forces, moving toward the northwest at Ostashkov. While this meant an attack against Army Group North rather than Army Group Center, it gave the German Command timely notice of the Red Army's concentration for an offensive against Staraya Russa.

The Russians detected the German retrograde movement around Rzhev at a very late stage and were thereby unable to prevent the successful reestablishment of a new, and much-straightened German front. Rzhev was evacuated on 3 March, Gzhatsk on the seventh, Sychevka on the eighth, Bely on the tenth, and Vyazma on the twelfth. The entire withdrawal movement was completed by $16 \mathrm{March}$, an operation which released about 10 divisions for other employment and shortened the front by 120 miles.

Throughout the month of January Red Army forces continued to exert pressure along the right wing of Army Group Center, and by early February were able to mount a sizeable offensive against the entire front of the German Second Army (then part of Army Group "B") and the right flank of the adjoining Second Panzer Army to the north. This assault soon assumed gigantic proportions and rolled back everything before it. On 8 February 1943 Soviet forces seized the important city of Kursk and pushed rapidly beyond, chiefly toward Glukhov and Sumy. The penetration pushed back Wehrmacht units from the area east of Orel in the north to the vicinity of Belgorod in the south, and gravely threatened not only the Second Army, but the Second Panzer Army as well, which now stood exposed in a bulbous salient around Orel.

In order to secure uniformity of action against this Soviet offensive, the Second Army was transferred from Army Group "B" to Army Group Center, while all available air forces of Luftwaffe Command East were immediately sent into action, fighting with good effect in checking the enemy inroads. After 9 February, air power had to be concentrated in support of the Second Panzer Army in the broad eastward extending bulge around Orel.

*This squadron, known as the Muenchhausen Squadron, was permanently assigned to Luftwaffe Command East (later Sixth Air Fleet). 
During this period the Red Army launched simultaneous attacks designed to cut off the Second Panzer Army, one from the Kursk area against the south and even southwestern flanks of the army, while three Soviet armies drove toward the south from the Sukhinichi area. *

The winter battle in the Orel area lasted well into March, compelling Luftwaffe Command East to commit its forces almost exclusively in support of the hard-pressed Panzer Army. It also carried out sizeable operations against enemy rail junctions at Kursk, Yelets, and Livny, which were especially important points in the Soviet logistical network. With heavy air support German forces north of Spas Demensk and those in the Orel area repulsed all enemy attacks in their sectors.

Again and again the air forces of Luftwaffe Command East intervened successfully in support of German ground forces, inflicting heavy losses in men and materiel upon the enemy throughout the entire depth of the Combat Zone. German flyers were especially active in the Orel area, where friendly armored and infantry units were engaged in counterattacks against a determined foe. On 20 February Luftwaffe fighters shot down 38 Soviet aircraft, and on the following day antitank air units destroyed 61 Russian tanks south of Orel, annihilating at the same time several Red Army troop and armor concentrations. 3 During the ensuing week strong German air forces supported ground operations north and south of Orel, helping to break up enemy troop concentrations, 4 and on 27 February these units bombed and strafed a number of hostile troop columns in the immediate vicinity of Orel, inflicting heavy losses, 5

The Luftwaffe continued its attacks in this sector through the end of February and early March, although flying conditions were far from ideal. On 18 March German airmen destroyed 116 Russian tanks in the southern part of this area, severely disrupting enemy offensive plans and assisting friendly forces to hold their positions. By the latter part of the month Soviet leaders were obliged to concede that their Orel offensive had been a failure. 6 In the meantime, the Red Army had launched a determined attack southwest of Vyazma, which was broken up on 31 March by well directed artillery and dive-bomber bombardment. 7

Early in April German photo-reconnaissance units received orders to carry out reconnaissance missions over the Soviet bulge at Kursk. In

*See Map No. 7 . 
spite of strong enemy ground and fighter defenses, two Luttwaffe planes executed this operation, obtaining excellent $20 \times 30 \mathrm{~cm}$ panorama photos (scale $1: 25,000$ ) from an altitude of 17,000 feet. The sector covered in this mission was approximately 7,200 square miles, * the largest tract ever taken in a single sweep by the squadron.

On 22 April Soviet bombers attacked the German airfield at Orsha, destroying aircraft of the 4th Strategic Reconnaissance Squadron of the 121 st Reconnaissance Wing and the 1st Strategic Reconnaissance Squadron of the 100th Reconnaissance Wing. 8 Because of this raid, the only operational strategic reconnaissance squadron available to Army Group Center was the 4th (the "Muenchhauseners") of the 14th Wing. Since this unit lacked manpower, it could only assist with reserve aircraft.

On the following day, crews from the two destroyed squadrons arrived and thereafter flew their missions from the same airfield. The additional aircraft servicing and the photo-processing work were handled smoothly by technical service personnel and the Photographic Section of the 4th Squadron, 14th Wing. 9 Through the success of its aerial reconnaissance operations, Luftwaffe Command East made a considerable contribution to all of the German ground defenses in Army Group Center, especially in the winter battles around Orel in the Second Panzer Army sector, where fighting lasted for many weeks.

At the end of April the mud season set in and brought all combat on the ground to a standstill. It was then no longer necessary for Luftwaffe Command East to fly continuous support missions for ground forces, especially those involved in cleaning out areas of Soviet penetration. It was therefore only logical to take advantage of the spell of relative quiet to rehabilitate the flying units and to improve their operational status. $10 f$ At long last there was also an opportunity to operate against railroads and rail installations, air bases, and particularly important industrial installations, deep in the Soviet rear. 11

From the point of view of ranges of available aircraft and that of location of well developed airfields suitable for supply movements, Combat

*12,000 sq. kilometers.

tSee Chart No, 6 for the strength and organization of German air fleets in the East in 1943. 


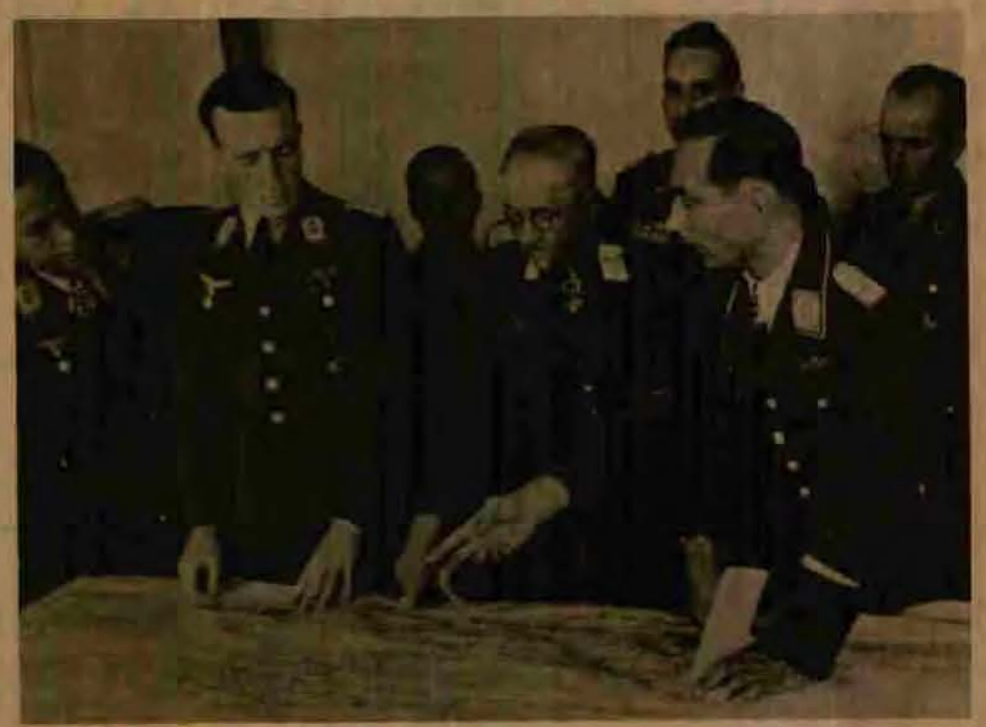

Figure 16

Situation conference, Sixth Air Fleet, in Russia, 1943: L. to R.: Maj. Helmut Mahlke (GSC), Op. Off., Maj. Guenther Seekatz (GSC), Asst. Op. Off., Generaloberst v. Greim, Col. Fritz Kless (GSC), Chief of Staff. Rear, L. to R. : Lt. Borski, Capt. Lichtenberg, and Meteorologist Jacobi. 


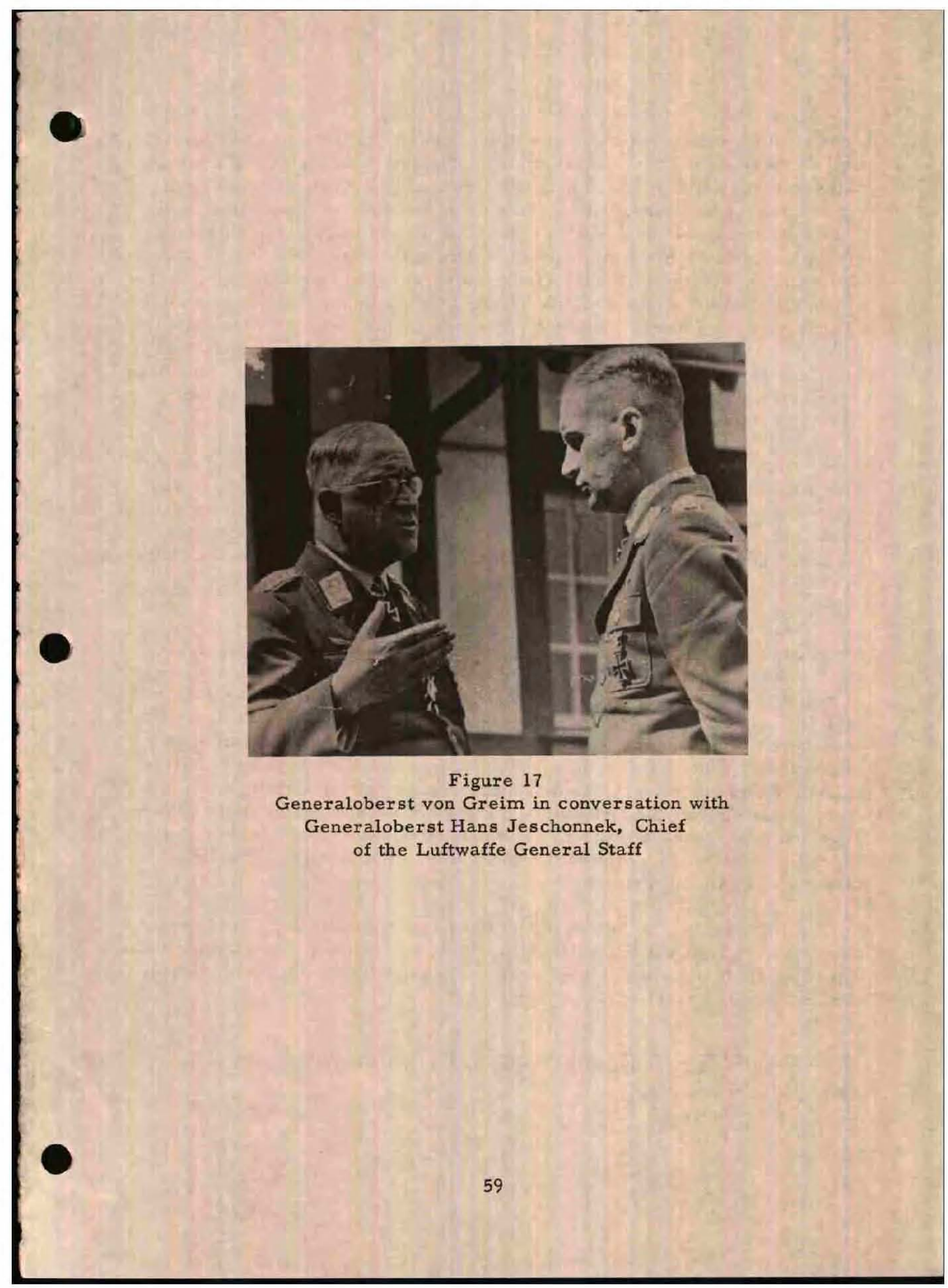


Zone Center, the operational area of the Sixth Air Fleet, was particularly well endowed. 12* Furthermore, the radio intercept service and air reconnaissance had detected large concentrations of Red Army units along the entire front of this area, with a clearly defined point of main effort in the Yelets-Kastornoye-Kursk sector. Besides these forces, they detected strong concentrations of air forces, including the First, Second, Third, Fifteenth, and Sixteenth Soviet Air Armies, which were placing heavy emphasis upon the southern flank of Army Group Center. The assemblage of such gigantic forces--apparently the movements were not even completed in May--could not be considered simply as an indication of preparations to meet a possible German summer offensive. Quite obviously, the Russians were getting ready for a new major offensive of their own against the German center.

Regardless of the decisions the German Supreme Command might take with respect to the conduct of operations in the East in 1943, it was clear at the end of April that the Sixth Air Fleet had to take decisive action against the assembling and concentrating of Soviet armies, mainly by striking enemy road and rail movements as well as airfields situated within the Red Army's concentration areas. $f$

On 12 May the Luftwaffe attacked by day and night a number of troop concentrations, enemy rail targets and air bases, and, five days later in both Combat Zones South and Center, destroyed a large number of Soviet transport aircraft and several important rail depots, 13 On 21 May German air units bombed and strafed Soviet troop concentrations, transport trains, and supply dumps in all of the probable areas of enemy main effort. Wherever reconnaissance planes detected important Russian activity German air forces made concentrated surprise attacks and, as a rule, achieved very good results. If key railroad bridges or thoroughfare axes could be destroyed, the resulting jam-ups would force troop and supply trains to come to a stop in the open, where they would be quickly dispatched by German flyers.

By day or night, whenever weather and visibility permitted, special aircraft were sent out to attack railway trains, even those at extreme ranges. These single plane attacks interfered seriously with the Russian concentration and supply operations.

*Luftwaffe Command East was redesignated Sixth Air Fleet on 11 May 1943. See figure 16.

tSee figure 17 . 
For the first time in 1943 the Luftwaffe also carried out concurrent attacks against enemy industrial targets, especially factories which were known to be closely connected with deliveries for Soviet concentrations and assemblies. For these missions, the Sixth Air Fleet frequently took temporary control of the bomber forces of the First Air Fleet (Combat Zone North) and of the Fourth Air Fleet (Combat Zone South).

On 2 June the Luftwaffe successfully attacked the rail depot at Kursk, followed by bombardments between 4 and 8 June of the Soviet tank factory at Gorkiy, on the 10 th by attacks on the rubber processing works at Yaroslavl, on the 13 th by the destructive raid on the marshaling yard at Yelets, and on 4 July by strikes against the supply bases at Yelets and Valuyki. 14*

Maj. Friedrich Lang, Commander of the 3rd Group, 1st DiveBomber Wing, wrote the following description of the highly successful surprise attack upon Kursk:

The previously mentioned attack against the Kursk railroad depot was flown with sizeable forces prior to the opening of the offensive. Wing headquarters units and our group were the first to make the attack, which opened a few minutes after four o'clock in the morning. Our approach flight was not interrupted, despite the fact that our planes were clearly visible against the closed and even cloud ceiling about 13,000 feet up. Only when the group was flying around the city, within the range of the defensive fire of the heavy [Soviet] antiaircraft guns, in order to get into position for our northward bombing run along the axis of the rail depot did the Soviet fighters take off from their bases east of Kursk. It was remarkable how many red and green Very lights were fired while the fighters were taking off, which gave us the impression that the Russians were in confusion and that we had perhaps taken them by surprise.

A Soviet fighter attacked the group's lead plane just as it was leveling out after the dive, but the group commander shot it down. The rest of the group escaped attack, although there must already have been quite a large number of Russian fighters in the air. Today I

*See figures 18 and 19 and Map No. 8. 


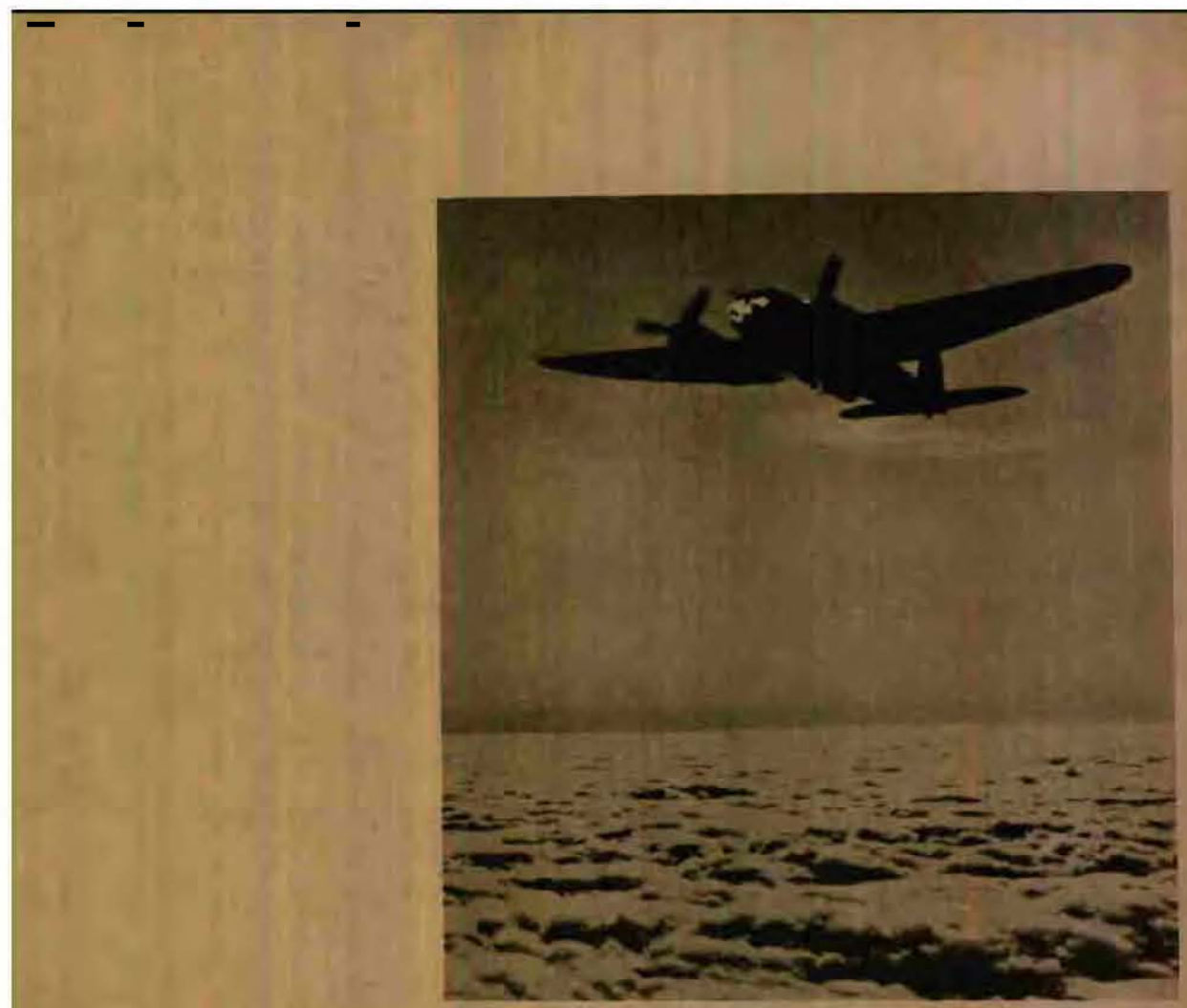

Figure 18

He- 111 bomber above the clouds en route to bombing mission over Gorkiy

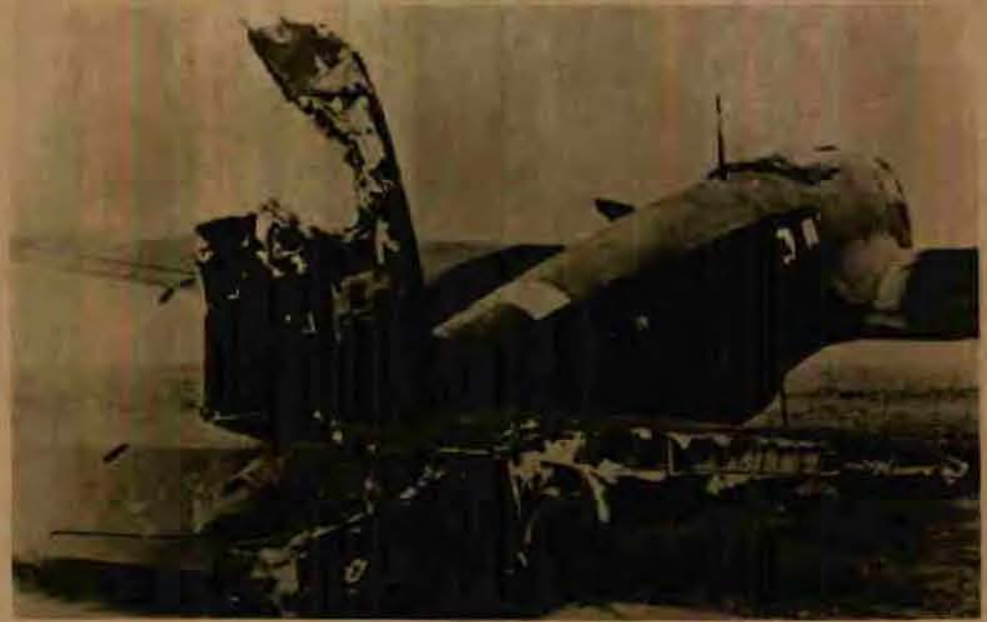

Figure 19

He-111 bomber returned from Gorkiy with tail section damaged by ramming from Soviet aircraft 
can no longer recall if our escort fighters were on hand. Our second group which attacked a few minutes later suffered heavy losses while leaving the target area due to enemy fighter action. 15

German twin-engine fighter forces also attacked Soviet operational airfields with a great measure of success, thereby making a substantial contribution to the reduction of Soviet combat strength. The main area of activity for German fighters, however, was over the Orel area, where protection was needed for the crowded airfields around Bryansk, Orel, and Sechinskaya. In these operations, fighters of the 51 st Fighter Wing (Moelders) shot down 40 Soviet aircraft on 5 June, 67 on the 8th, and 65 on the 10 th.

As part of the training program, crews without combat experience or training in blind flying and navigation were used in attacks on villages known to be occupied by partisans, particularly in the difficult terrain around Bryansk and Kletnya, much of which was heavily forested. In this way all units could use their full striking force against targets in Soviet held territory.

The Russians were becoming steadily more active in the air. 16 Most of their missions were daylight or night nuisance raids in the near front sectors, placing particular emphasis upon the Second Army and Third Panzer Army areas. After units of the Sixth Air Fleet had completed their first successful attacks against Soviet industrial targets, Red air forces countered by launching repeated night attacks against German airfields, traffic centers, and supply points. Major Lang, a German group commander, gives an account of one of these Soviet air strikes:

The only daylight attack against the Orel rail depot by Soviet ground-attack units occurred shortly before the offensive and ended with a resounding defensive success for the German fighters. We were resting on that day and could observe the entire attack well from our positions. There was a cloud cover of about $4 / 10$ at 2, 600 feet. A sizeable Soviet fighter force, flying above the clouds, approached the town from the east. German fighters took off; there was a little firing, and the Soviet fighters turned back toward the east. At this moment a large number of IL-2 planes flew in at an altitude between 660 and 1,000 feet. Before they could even reach the rail depot they came under attack by the German fighters which were already in the air, and by others which continued to take 
off, One could see as many as foux and even more II-2's crashing to the ground simultaneously.

What struck us was the stubborn way in which the Russians flew. Hardly any of them tried to fly in defensive curves. The final score showed 70 Soviet planes downed. Interrogation of captured Russian pilots revealed the plan of attack: Soviet fighters were to engage the defending [German] fighters at Orel in combat and decoy them eastward. It had been assumed that the IL-2 units could then attack their target undisturbed.

Although some of these Soviet bombing attacks did cause considerable damage, particularly in the case of the Orel and Bryansk rail depots, the results achieved were generally meager and had no decisive effects. 17

The obvious Soviet intention of using air attacks and increased partisan activities to deprive German forces in the Orel salient of their supplies, thereby reducing the German defensive capacity--this was clearly a strategic objective--could therefore be considered a failure.

Flak artillery forces also participated very effectively in the successful defensive operations, In the Orel area, units of the 12th Flak Division shot down 40 Soviet aircraft ( 20 of them at night) in the month of June 1943, while during the same period batteries of the 18th Flak Division (a unit deployed primarily in the Smolensk-Roslavl area) successfully engaged 130 Soviet planes during daylight and 617 at night. * In the Second Army sector the 10th Flak Brigade was primarily employed in repelling small-scale night harassing attacks.

In the Orel-Bryansk sector, units of the German night fighter service which were improvised by the Sixth Air Fleet, together with searchlights and radar equipment mounted on railway cars, shot down approximately 30 Soviet aircraft between April and June 1943.

In summary it can be said that the major assemblies and concentrations of very large enemy air, armored, and other ground force organizations in the Kursk-Kasternoye-Sukhinichi sector were detected during May and June by the excellent aerial reconnaissance and combat

*See figures 20 and 21. 


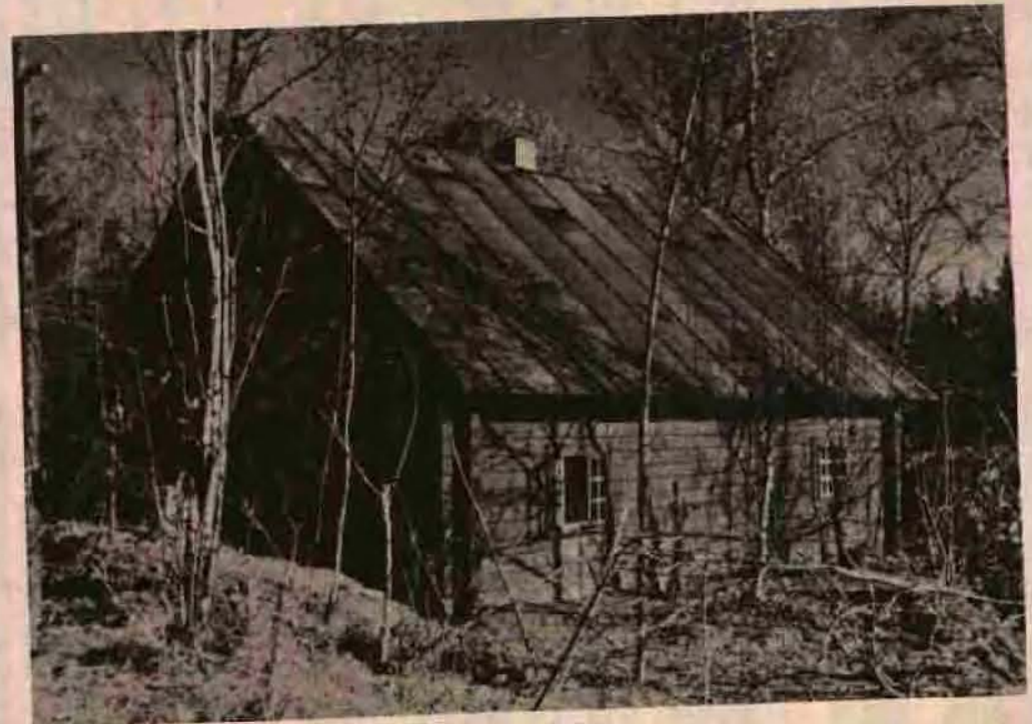

Figure 20

Command Post of a flak division near the Dugino airfield camouflaged as a farm house

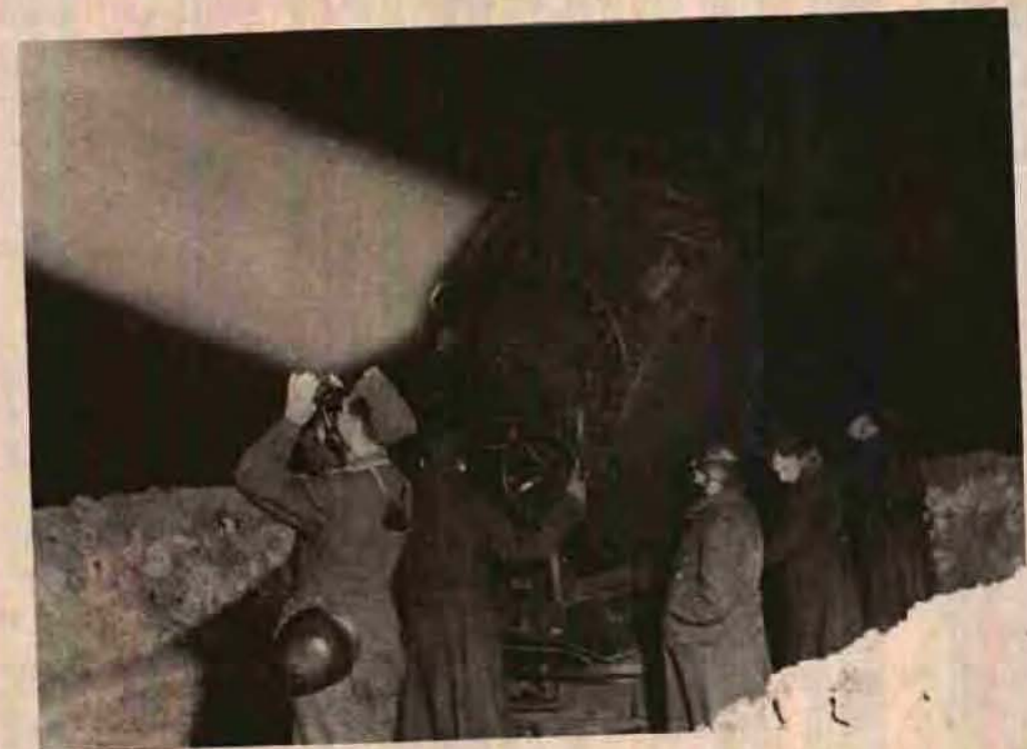

Figure 21

Searchlight unit near Orel scanning the skies for attacking Soviet aircraft 
work of the Sixth Air Fleet. * The air fleet correctly assumed these concentrations to be a preparation for a major Soviet offensive, and reported its findings and intexpretations at an early stage to the Commander in
Chief of the Luftwaffe.

By exploiting various factors such as timing, prevailing weather conditions, and visibility in order to achieve surprise, by frequently changing objectives, and by combining high and low altitude attacks with turbing the detected Soviet concenth Air Fleet succeeded in seriously dissector during April, May, and June. Luftwaffe inflicted very heavy June. In the course of these operations the units and even compelled the personnel and materiel losses upon Russian approximately to the Kastorn to move their railheads farther to the east, forced the Red Army to malke time-Livny-Shchigry area. This, in turn, proved to be extremely costly repeated German air attacks. 18

Because the Sixth Air Fleet lacked sufficient force, particularly suitable special units, and because its operational area was so vast, it was unable to seal off the probable battle area or to annihilate the enemy concentrations, 19 With its units committed in too many theaters of operin the Arctic, the such a mission.

\section{Operation ZITADELLE}

The Problem of Continued Operations in the East in 1943

The operations of Army Group South came to a close with the onset of the spring mud period. As has been noted, the German Command and its stubbornly courageous troops were able to reestablish a firm front at the end of March 1943 and hold it against all Soviet attacks. The winter crisis of $1942-43$, which had threatened to assume catastrophic proportions grave enough to decide the outcome of the entire war, was past. During the 1941 and 1942 campaigns the German Supreme Command had failed in its efforts to deal an annihilating blow and to conquer the Red Army. Instead, the Wehrmacht had been forced back by costly retrograde movements

*Editor ${ }^{1}$ Note: Its advanced command post was at Kamenets, 9 miles north-northeast of Kromy. 
to its old jump-off positions. In the spring of 1943 the German Command was thus faced with the difficult military and political problem of deciding how the war in the East was to be prosecuted or how it could be brought to a favorable conclusion.

Was there any chance of finding a solution? Was it possible at least to end the war without a military decision, provided Hitler as the supreme military commander and supreme political leader was willing to seek such a solution and to create the necessary political conditions therefor?

What in any circumstances was the only feasible way to continue operations in the East in 1943? A full and critical examination of the various possibilities would exceed the scope of this presentation, which is primarily concerned with the operations of the Luftwaffe in the Eastern Theater of Operations in 1943. 20 Yet, this problem which had to be solved will be outlined briefly in order to facilitate an understanding of the aerial operations which were to follow.

In the spring of 1943 the German armies in the East were stretched along a front deep in the interior of the Soviet Union, extending approximately from Leningrad through Novgorod, Smolensk, Sevsk, Rylsk, and Kharkov to Taganrog on the shores of the Sea of Azov. * They had been able to stabilize these lines in most places, and still represented an imposing military power. 21 The Russians had suffered gigantic losses in men and materiel, but their resources seemed literally to be unlimited. Of course Hitler neither believed this nor admitted that it could be true. The Soviet conduct of the war was really typical of the Russo-Asiatic mentality:

. . the brutal expenditure of masses in attack. Men and materiel were usually employed mulishly and ruthlessly, but always with greatest effectiveness. Men and equipment were as dust in Stalin's hands. This son of the Ossetian Mountainst was no respecter of human life. He chose the most inhuman and costly methods--the method of oriental sultans and Mongolian khans---and he could afford to do so.

*Editor ${ }^{5}$ Note: See Map No. 7. This, of course, does not include the Far Northern Combat Zone, stretching from the Leningrad area through the forests northward to the Barents Sea. See also Chart No. 2.

tBorn in 1879 in Gori, Georgia, in the Caucasus. 
His manpower reserves were inexhaustible. A dequate numbers of reserve divisions were at his disposal to enable him to pull out shattered divisions and replace them with new ones, 22

Hitler was unable to divest himself of his habit of wishful thinking, which invariably led him to minimize the power resources of the Soviet enemy. 23 He was fully aware that American newspapers estimated Soviet losses (including civilians who had died of hunger) at $30 \mathrm{million}$, and reckoned that the Russians had lost between 12 and 14 million men of military age and qualifications. In view of such heavy losses he thought it could definitely be expected that the Soviet Union would collapse at some time or would sink into an endless agony similar to that of China, 24

One of the major problems in the Russian campaign was how to control the vast spaces of the Soviet Union. It was quite evident that this problem could only be mastered through numerical strength, meaning a sufficient superiority in manpower and arms to defeat the Soyiet enemy in his vast special area. But, there was considerably less chance of Germany being able to muster the required forces to seek this combat decision in 1943 than had been the case at the beginning of the campaign in 1941 or even in 1940 , when Operation BARBAROSSA was in the planning stages. 25 Because of the increasing pace of Soviet armament activities and the mounting volume of Anglo-American deliveries, * the strength ratio was continually becoming more and more favorable to the Soviet Union. It was therefore obvious to every reasonable person that in 1943 it was no longer possible to completely defeat the Soviet enemy. In fact, by that year, because of its great numerical inferiority alone, the German Wehrmacht in the East was no longer able to stage a major offensive aimed at distant objectives as had been the case in 1941 and even in 1942.

It must also be said that from the standpoint of quality the Wehrmacht in the Eastern Theater of Operations had lost much of its striking

*Editor's Note: In 1942 the United States delivered 2, 343 combat aircraft to the Russians, and between January and April of 1943 delivered an additional 1, 383. See Office of Statistical Control, USAAF, Army Air Forces Statistical Digest, "World War II," Washington: December 1945, pp. 129-130. Between 1941 and 1945 the United States also gave enormous quantities of other items to the Red Army, including 281, 606 trucks, 920 combat vehicles, and 7,172 tanks. Theodore E. Whiting, Carrel I. Tod, and Anne P. Craft, The United States Army in World War II, Statistics: Lend-Lease, Washington: Office of the Chief of Military History, U.S. Army, 15 December 1952, pp. 24-34. 
power as a result of losing so many troops, especially commissioned and noncommissioned officers, * men who had been superbly trained in peacetime and hardened by combat experience. Another critical factor was the fact that deficient production, and therewith an insufficient supply, especially of fuel, $t$ severely reduced the combat power of the Wehrmacht in the East. This was true despite the fact that German forces had been able to overcome the shock of costly withdrawals and the Stalingrad catastrophe, and to reestablish combat morale and good training standards.

Hence, the only possible course of action in the East was defense, and this did not imply a defense which had become torpid and rigidly restricted to repelling attacks dictated by the uncertain caprices of the enemy, but an extremely active and flexible type of defensive operation, always with clear and limited attack objectives designed to weaken the Russians and make them inclined to accept a military and political draw.

Of course, in official or military circles of any size there was no opportunity to discuss the hope for a draw, since anyone who did not profess to believe in final victory (Endsieg), or expressed even the slightest doubt about it, was considered a defeatist and a traitor to the Fatherland. $f f$

\#Editor's Note: By August 1943 German losses in the East totalled almost $1,500,000$ dead, wounded, and missing. This was almost 50 percent of the strength of the German armies on the Eastern Front at the time of the invasion, 22 June 1941. See Walter Goerlitz, Der Zweite Weltkrieg 1939-I945 (The Second World War T939-I945), Vol. 2, Stuttgart: Steingrueben Verlag, 1952. Cited hereafter as Goerlitz, Vol. II.

fIn addition to the regular refining and processing of petroleum, much of Germany's gasoline was being produced synthetically.

ffEditor's Note: The closer the relationship between Hitler and his officers, the less able were these officers to undertake either independent action or to express ideas displeasing to the Fuehrer's ears. Generalleutnant Walter Warlimont, Deputy Chief of the Wehrmacht Operations Staff, commented: "Lest anyone should misunderstand him [Hitler], as the fronts began to collapse in all directions he [Hitler] would say over and over again to those around him, ... 'anyone who speaks to me of peace without victory will lose his head, no matter who he is or what his position. "' Generalleutnant Walter Warlimont, Inside Hitler's Headquarters $1939-1945$ (translated from the German by R. $\overline{\mathrm{H}}$. Barry), New York: Frederick A. Praeger, 1964, p. 462. Cited hereafter as Warlimont, Inside Hitler's Feadquarters. 
Thus the desire that the war against the Soviet Union would end in a draw remained an objective, albeit an unexpressed and invisible one, in the strategic planning at all higher military command levels, and was a hope concealed in the minds of many. *

The expectation of being able to deal the enemy repeated telling blows from the defensive was frustrated by Hitler, who was unwilling in any circumstances to allow the Red Army to retain the initiative. Therefore the plan Operation ZITADELLE (Citadel) finally evolved. While the victories achieved in the winter campaign between the Donets and Dnepr Rivers, and at Kharkov, had made it possible to reestablish a defensive line from Taganrog along the Mius and Donets as far as Belgorod, enemy forces still held a large salient extending far to the west (north of Belgorod) in the boundary area between Army Groups South and Center. The Soviet main line of resistance in this place described a wide curve from Belgorod through Sumy and Rylsk to the area southeast of Orel, and enclosed the Kursk sector. This bulge which protruded into the German front was far more than a mere beauty blemish. It extended almost 300 miles along the front lines, consequently forcing the Wehrmacht to deploy considerable forces in that area to seal it off in the north, west, and south, and it severed the rail route from Army Group Center to Kharkov, depriving German forces of what had been one of their most important lateral communication routes behind the front. Finally, it gave the Russians a staging area for an attack directed at the northern flank of Army Group South and at the southern flank of Army Group Center.

It would have been particularly dangerous if the German Command at any time should plan a counterattack from Kharkov against 6 ome future Soviet offensive in the zone of Army Group South. For this reason, Army Group South had originally intended to exploit its successes achieved at Kharkov to clean out this salient while the Russians were still off balance and before the onset of the mud season. The plan had to be dropped, however, because Army Group Center announced that it was unable to participate in the operation. Although the Red Army had become very much weakened by its defeat at Kharkov, the forces available to Army Group South would still have been too weak to attempt to clean out such a large area,

*Editor's Note: Although Walter Goerlitz mentions that there were some inclinations on the Soviet side for a negotiated peace, the central body of the Communist Party remained dedicated to the "war to annihilate fascism." See Goerlitz, Vol. II. 
The bulge had now become an objective for an attack in which the German Command would have to make the first move. The tactical importance of the objective has been described. Apart from the fact that removal of the salient would release a considerable number of German units for employment elsewhere, an added incentive for the attack was the possibility that, through synchronized attacks from the north and south, relatively strong Soviet forces could be cut off.

However, from Army Group South's point of view, the planned operation would also serve another purpose, since it assumed with certainty that the Russians would throw in their strategic reserves (then assembled opposite the northern flank of Army Group South and the southern flank of Army Group Center) at an early stage in order to retain possession of the strategically important area. If the Germans could stage their attack soon enough after the close of the mud season, it was likely that the Soviet Command would be compelled to commit its armored and motorized corps and armies before they had completed their rehabilitation. This would have been a distinct advantage for the Wehrmacht, which could then hope to complete an earlier rehabilitation of its own units.

If the Soviet armored reserves could be destroyed in the battle, it would then be possible to strike a new blow, this time at the Donets line, or in some other area. The development of these conditions was just as important an objective in Operation ZITADELIE as the removal of the bulge itself, desirable as the elimination of this threat was. 26

The restricted scope of the objective in this last German offensive in the East reveals most strikingly how the factors of space and numerical strengths influenced the conduct of operations in Russia in 1943. In 1941, German armies had attacked on a frontage of about 1,200 miles to rout the Red Army in a series of major battles of envelopment. $27 \%$ In 1942, the German drive on Stalingrad and the Caucasus had taken off from a frontage of only 360 miles, but with an immensely far-flung objective. In 1943 , the planned offensive was to begin on a frontage of only 120 miles, and the objective was only 90 miles away.

*Editor's Note: See Generalleutnant Hermann Plocher (Ret.), The German Air Force versus Russia, 1941, USAF Historical Studies No. $1 \overline{53}$ Maxwell AFB, Alabama: USAF Historical Division, ASI, July 1965. 


\section{The Plan of Attack for Operation ZITADELLE}

The relatively straight German main line of resistance from Taganrog to Leningrad was interrupted by a Soviet wedge with a base of approximately 120 miles and a depth of about 90 miles, protruding west of Kursk. Pursuant to directives from the Army High Command, the enemy wedge was to be cut off at its base in a pincer movement, with Army Group Center attacking from the north and Army Group South from the south. Soviet forces in the sector were to be annihilated, $28 \%$

In the south, the Fourth Panzer Army (Generaloberst Hermann Hoth) was assigned the mission of breaking through to Kursk. Army Force Kemp had the mission of covering the breakthrough operation by "offensive-action. "29 From the north, the Ninth A rmy (Generaloberst Walter Model) was also to break through to Kursk to meet the Fourth Panzer Army. The Fourth Air Fleet was to support the two armies attacking from the south, while the Sixth Air Fleet was to support the drive from the north.

The two army group commanders, Field Marshals von Mansteint and von Kluge, held the view that Operation ZITADELLE must be staged as soon as possible, therefore immediately after the termination of the spring mud season, probably about the beginning of May. The planned intention was to strike the enemy while he was still off balance, 30 It was, of course, obvious that the Russians would not remain idle during this time, and that they would also take advantage of the period of inactivity brought on by the muddy season to reequip their units and bring them up to strength, to reorganize their command, and to prepare new offensive plans. Therefore, the sooner the German offensive commenced the greater would be the chance that it would stagger the enemy before he had completed his offensive prèparations.

Hitler's order of 15 April 1943, which prescribed an attack with limited objectives against the Kursk bulge, commenced as follows:

I have decided to carry out the offensive "Zitadelle" as soon as weather conditions permit, as the first of this year's attack plans.

*See Maps Nos. 7 and 11.

tSee figure 22 . 


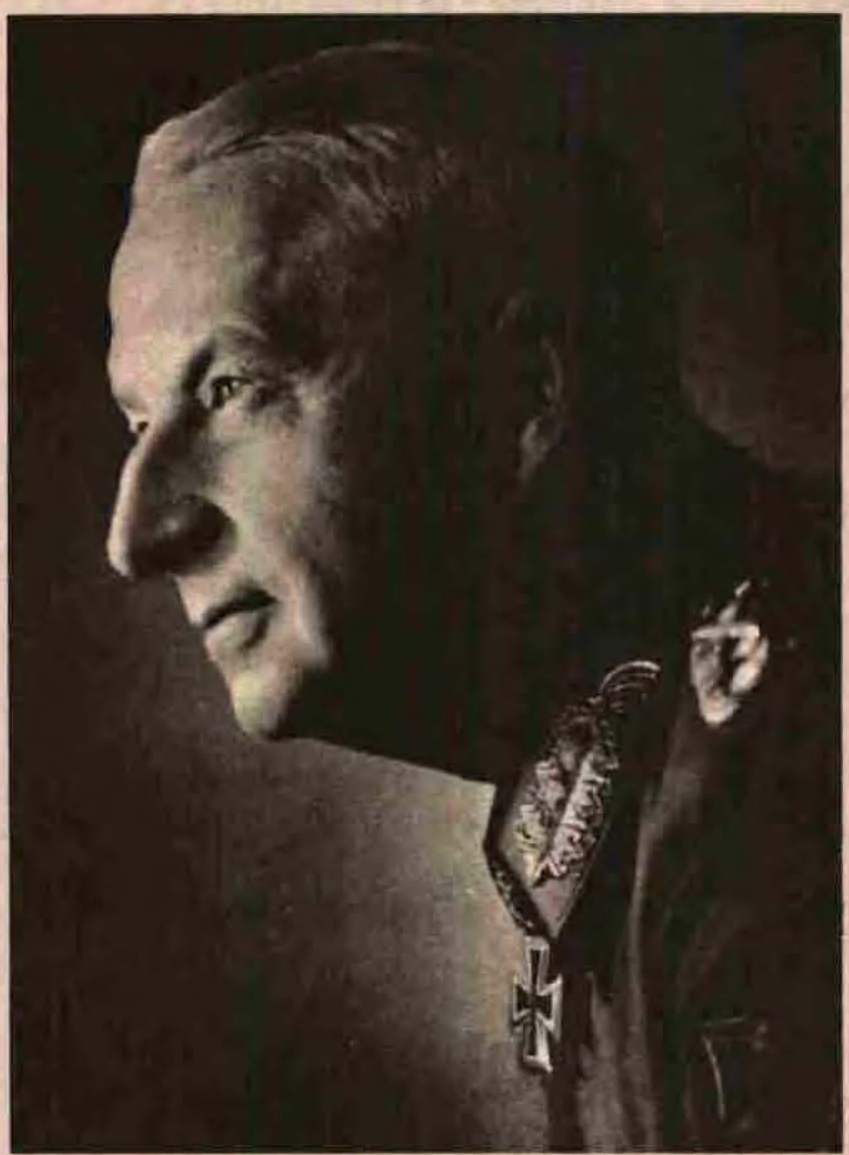

Figure 22

Field Marshal Exich von Manstein, Commander in Chief, Army Group South 
This attack is therefore of decisive importance. It must succeed quickly and completely. It must put the initiative for this spring and summer in our hands.

All preparations must therefore be made with the greatest care and energy; the best units, the best weapons, the best commanders, and large quantities of ammunition shall be committed in the areas of main effort.

Every commander and every man must be filled with the decisive meaning of this attack. The victory of Kursk must have the effect of a beacon for the entire world. 31

The Fuehrex, however, postponed the opening of the offensive again and again because he considered it essential to reinforce the available panzer forces with the new "Panther" and "Tiger" tanks, which had just been placed in serial production. * The commanding generals of the two army groups remonstrated repeatedly that time would favor the Russians, but. Hitler adhered to his decision to postpone the attack.

The views of the army group commanders were supported by Generaloberst Jeschonnek, Chief of the Luftwaffe General Staff, during a Fuehrer Conference in Munich on 4 May 1943. Jeschonnek declared that, from the Luftwaffe's point of view, a postponement of ZITADELLE offered no advantages whatever, since it was impossible to effect any material increase in the strength of the combat air forces, and since changes in the air situation indicated that the enemy appeared to be planning a decisive offensive in the sector of Army Group South. 32

On 1 July 1943 Hitler held a conference at his headquarters at Rastenburg in East Prussiat to which he summoned all Army and Luftwaffe commanders from corps level upward who were participating in Operation ZITADELIE. During this meeting he finally announced his decision to

*Editor's Note: The "Panther" (Pzkw V), a tank weighing about 40 tons, armed with a $75-\mathrm{mm}$. gun, appeared in 1942. The "Tiger" (Pzkw VI) was in the 60-ton weight class, and was armed with the very excellent long-barreled $8.8 \mathrm{-cm}$ antitank gun. See Generaloberst a. D. Heinz Guderian, Exinnerungen eines Soldaten (Recollections of a Soldier), Heidelberg: Kurt Vawinckel Verlag, 1951, pp. 250-257.

tAbout 110 miles southeast of Koenigsberg. 
begin the operation on 5 July, opening the attack with a bold, tightly concentrated, and speedily executed drive by one army each from the Belgorod area and the area south of Orel, respectively. The plan was to encircle the Soviet forces present in the Kursk area and to annihilate them by a concentric attack. $33 \%$

\section{Preparations for the Strongest Luftwaffe Concentration for ZITADELLE}

Reichsmarschall Goering ordered the following measures for the planned offensive. The Fourth Air Fleet, supported by the consolidated units under the command of the VIII Air Corps, was to back the attack by the southern group (Army Force Kempf and Fourth Panzer Army), while the Sixth Air Fleet, with those forces which were consolidated under the command of the Ist Air Division, was to support the attack by the northern group (Ninth Army).

Insofar as was possible, both air fleets were to strip the units within their commands of forces, including flying, flak, and signal troops, so that they would have available the real bulk of their forces for the development of well defined concentrations of power in the two major attack areas. Other air forces were to be moved in from the outside, such as, for example, from the First Air Fleet area (Combat Zone North).

The Fourth Air Fleet, under General der Flieger Otto Dessloch, $f$ with command post at Dnepropetrovsk, directed the VIII Air Corps (Generalmajor Hans Seidemann), which had its headquarters at Mikoyanovka, 18 miles south of Belgorod. Assigned to it were:

*See Map No. 7.

fFreiher $r$ von Richthofen was promoted to Field Marshal 16 February 1943, and assumed command of the Second Air Fleet in Italy 12 June 1943. Von Manstein made a plea for his retention in the Russian area for ZTHADELLE, and declared, "My efforts to secure the return of von Richthofen to command the Fourth Air Fleet failed, and led only to a sharp controversy with Goering, who was unwilling to admit how decisively important the influence of a personality such as von Richthofen was for the combat forces." Generalfeldmarschall Erich von Manstein, Verlorene Siege (Lost Victories), Bonn: Athenaeum Verlag, 1955, p. 496. 
Reconnaissance:

2nd Strategic Reconnaissance Squadron, 11 th Wing

6 th Wing ( $2 \mathrm{Me}-109,5 \mathrm{Fw}-189$, and

3 night squadrons)

\section{Fighters:}

3rd Fighter Wing ( $3 \mathrm{Me}-109$ groups) 52 d Fighter Wing ( $3 \mathrm{Me}-109$ groups)

4th Group, 9th Antitank Air Wing

(4 HS- 129 squadrons)

\section{Fighter--Bombers:}

1st Ground-Attack Wing (2 Fw-190 and HS- 129 groups)

2nd Dive-Bomber Wing ( $31 / 3 \mathrm{Ju}-87$ groups)

77th Dive-Bomber Wing ( $3 \mathrm{Ju}-87$ groups)

\section{Bombers:}

3rd Bomber Wing (2 Ju-88 groups) 27 th Bomber Wing ( $3 \mathrm{He}-111$ groups)

55th Bomber Wing ( $3 \mathrm{He}-111$ groups)

Other Air Units:

A group of harassing bombers of various types

Several liaison squadrons

1 Ju-52 air transport squadron

2 air signal regiments
Kharkov-East

Airfields southwest of Mikoyanovka

Kharkov-East

Airfields southwest of Mikoyanovka

Airfield near Mikoyanovka

Two airfields south of Belgorod

Kharkov-East

Airfields at Tolokonoye and Bebarovika south of Belgorod

Poltava

Dnepropetrovsk and Zaporozhye

Kharkov-East

Kharkov-North

Kharkov-North

Kharkov-North

Kharkov-North 
The VIII Air Corps also had tactical control over the Hungarian Air Division, composed of the following units, all located at KharkovSoutheast:

1 Ju-88 strategic reconnaissance squadron

1 FW-189 tactical reconnaissance squadron

$1 \mathrm{Me}-109$ fighter group

$1 \mathrm{Ju}-87$ dive-bomber group

$1 \mathrm{Ju}-88$ bomber squadron

All in all, the VIII Air Corps at the end of June thus had a striking power of 1, 100 operational aircraft. 34 The Fourth Air Fleet ordered this corps to secure air superiority over the line of advance of the attacking German ground forces in the south and to support both Army Force Kempf and the Fourth Panzer Army. For these purposes, the available air forces were to be closely concentrated in the areas of attack, especially in advance of the II SS Panzer Corps, in order to facilitate the forward thrust of the spearhead units. All air units were to be used exclusively in tactical support missions, against targets within the battle area, the strongly developed Soviet defense positions, and Soviet artillery emplacements. Rail and road targets were to be attacked only if large transport movements were observer

The Fourth Air Fleet also controlled the I Flak Corps (Generalleutnant Richard Reimann) and Luftwaffe Administrative Area Command Kiev (General der Flieger Bernard Waber). * The I Flak Corps received instructions to employ three regiments as a strong air defense force for the extremely crowded airfields, placing main emphasis upon the Kharkov sector; to assign one flak regiment as antitank artillery in the Fourth Panzer Army sector; and to deploy its units so as to provide an adequate air defense for the ground troops.

Air Administrative Area Command Kiev had the responsibility of developing the ground service organization within the VIII Air Corps area, for maintaining supplies at the tactical airfields from which assigned flying units would operate, and for transporting and controlling Luftwaffe supplies, both prior to and during the offensive.

*Editor's Note: Waber, an Austrian, was tried and executed late in the war for subverting (misuse and misappropriation of materials) the defensive power of the Wehrmacht. See biographical section in the back of this study and Chart No. 4. 
Situated in the northern part of the concentration area was the Sixth Air Fleet under Generaloberst Ritter von Greim. This organization commanded the Ist Air Division (Generalmajor Paul Deichmann), which had its command post near the Orel airfield, and which was directly responsible for the conduct of combat air operations. At the end of June the division had a striking force of 730 aircraft, consisting of 3 tactical reconnaissance groups, one each with the Second and Ninth Armies and the Second Panzer Army, and the following units (located at airfields in the Orel-Bryansk-Shatalovka a rea):

\section{Fighters}

51 st Fighter Wing (31/3 Fw-190 groups)

54th Fighter Wing ( $\left.\mathrm{Fw}-190^{\prime} \mathrm{s}\right)$

2 to 3 antitank squadrons (known as the 14 th Squadron)

\section{Fighter-Bombers}

1st Dive-Bomber Wing ( $3 \mathrm{Ju}-87$ groups)

1st Twin-Engine Fighter Wing (1 $1 / 3 \mathrm{Me}-110$ groups)

\section{Bombers}

3rd (Ju-88) Group, 1st Bomber Wing

4th Bomber Wing (2 He-111 groups)

51 st Bomber Wing (2 Ju-88 groups)

$53 \mathrm{rd}$ Bomber Wing (2 He-111 groups)

\section{Other Air Units}

1 to 2 squadrons of harassing bombers, liaison squadrons, and Luftwaffe signals regiments

Sixth Air Fleet ordered the 1st Air Division to attack the overcrowded Soviet airfields in the Kursk region, employing at the same time certain of its elements against Soviet artillery positions around Maloarkhangelsk; then to concentrate its forces ahead of the XXXXVII Panzer Corps, which would spearhead the ground attack, silencing enemy artillery; and to attack Russian units in the Second Panzer Army's line of advance. Such actions were to be given prior approval by the air fleet headquarters. Besides these important tasks, the air division was to maintain fighter patrols over the entire assault area. 
The 1st Air Division controlled a number of ground units as well, including the 12th Flak Division under Generalleutnant Ernst Buffa (CP located at Orel), and the 10th Flak Brigade, commanded by Generalmajor Paul Pavel (CP located at Konotop). * The 12th Flak Division, through its 5 regimental staffs (which included a railroad flak regiment), controlled about 16 mixed flak battalions ( 12 motorized and 4 truck-drawn), each with 3 heavy and 2 light batteries; 7 light battalions made up of 5 motorized and 2 truck-drawn units; 3 railroad flak battalions of 3 batteries each; and 2 to 3 searchlight battalions of 3 batteries each.

The mission of the 12th Flak Division was to provide antiaircraft protection for German supply bases, especially around Orel, provide at least minimum necessary antiaircraft defense of the operational airfields, protect the attacking German divisions' main supply routes against Russian air attacks, and, what was unusual, have its forward batteries participate in the artillery preparation fire on the morning of $5 \mathrm{July} 1943$.

The 10th Flak Brigade had a single regimental staff which controlled 2 motorized and 2 to 3 truck-drawn flak battalions, 1 light flak battalion, 1 improvised railroad flak battery, and 2 searchlight batteries. Its mission was to provide antiaircraft protection in the Second Army sector, with main concentration in the Konotop area, and to prepare for the deployment of its motorized batteries for air defense of German ground troops.

In addition to the above-mentioned organizations, the Sixth Air Fleet assumed command over a number of special units for the impending Operation ZITADELLE. These consisted of 1 night-fighter group, 1 strategic reconnaissance group of 2 to 3 squadrons, and 2 Luftwaffe signals regiments (all in the Orel area), a Luftwaffe operations staff, the 3rd Air Command, an ad hoc organization held ready to commit its attached units, if necessary, to action northeast of Bryansk, $f$ and the XXVII Special Air Administrative Area Command (previously designated Air Administrative Area Command Moscow). If

This latter unit, commanded by Generalleutnant Veit Fischer, operated from its headquarters at Minsk and had the mission of developing

*See Chart No. 4.

tAs events worked out, this was not deemed necessary.

ttSee Chart No. 2. 
the ground service organization, building up supplies for the coming operation, securing the logistical life lines during the course of the battle, and making preparations for development of a ground service organization in the Kursk area if the tactical objectives should be achieved.

Such a massed concentration and commitment of air forces within small areas involved extraordinary preparations. The development of the ground service organization, and the procurement of additional necessary personnel and materiel for the purpose, particularly the build-up of large stockpiles of supplies, were handled by Air Administrative Area Command Kiev for the VIII Air Corps (attacking in the south), and by the XXVII Air Administrative Area Command (Minsk) for the 1st Air Division (attacking in the north).

Since the existing airfields were inadequate for the many air units which were to be employed, a number of new tactical air bases and forward airfields had to be speedily reconnoitered and developed for operations, making sure that sufficient stocks of fuel and ammunition were on hand. In the Orel sector alone, the number of airfields was increased from 3 to about 15,35

Equipment supply points, aircraft recovery detachments, mobile field workshop battalions, workshop platoons, Reichs Labor Service (Reichsarbeitsdienst or RAD) battalions, air base command staffs, airfield operations companies, and supply columns were assembled in the Kursk area and prepared for their coming tasks, giving special attention to the immediate build-up of supplies at the airfields.

Little difficulty was encountered in stockpiling all types of ammunition. Enough ammunition was stored at each airfield in the VIII Air Corps sector for 10 missions, and arrangements were made to assure an adequate supply of bombs for 15 days of major battle at each field in the 1 st Air Division area.

The supply of fuel proved to be a serious bottleneck for the Wehrmacht. This situation had been generally difficult to master for some time because of deficient production. As a result, the Sixth Air Fleet in June received only 5,722 tons of $B-4$ fuel against a total consumption of 8,634 tons, and only 441 tons of C-3 fuel (so necessary for Fw-190 units) against 
a total consumption of 1,079 tons. * Efforts were made to surmount these difficulties by a partial redistribution of existing stocks, using the uneconomical means of air and truck transportation.

The already very serious rail transport situation was worsened considerably by the steadily increasing number and scope of partisan sabotage operations against the few available supply routes. It seemed obvious that this increased partisan activity was directed by the Soviet Command for the dual purpose of interrupting and delaying German military preparations and of weakening the Wehrmacht's defensive capabilities against impending Red Army operations. Partisan actions reached a peak in June of 1943 with 841 separate acts of sabotage, including the loss or damage of 298 locomotives, 1, 222 railway cars, and 44 bridges in Combat Zone Center alone. During this time the partisans stopped rail movements at an average of 24 points daily. $36 t$ The conduct of air operations was governed largely by fuel supplies, so it became essential to introduce what could only be termed "fuel availability tactics." Power concentrations had to be developed not so much by the assignment of air units as by the quantities of fuel which could be released for the purpose. In order to have air power available for particular crises and major phases of battle, it became necessary to refuse air support in many situations which would normally have been recognized as critical. Every assigned mission had to be carefully examined to determine whether it was really worth the fuel expenditure. In deciding what type of units to employ, it often became necessary to accept certain disadvantageous conditions because of the possibility of saving a few tons of fuel. 37

*Editor ${ }^{\mathrm{T} s}$ Note: B-4 (blue) aviation fuel (rated at 91 octane) was primarily used for bomber and general-purpose aircraft. C-3 (green) aviation fuel was almost exclusively a fighter fuel, and contained high percentages of aromatic naphtha, which gave it an excellent rich-mixture performance. By 1943, this fuel was rated at 97 octane (weak mixture) and from 110 to 130 (rich mixture). DB-601 and BMW-801 engines were supposed to use C- 3 fuel, although B-4 and even other types were used in emergencies. The Luftwaffe needed 350,000 tons of fuel per month in 1943, but, because of deficient production and transportation problems, only 160,000 tons were delivered each month. See "Die Betriebsstofflage in Deutschland 1939-1944" ("The Power Fuel Situation in Germany 19391944"), C/I/5, Karlsruhe Document Collection.

tEditor's Note: Combat Zone Center was the most active area of partisan warfare. See General der Flieger a. D. Karl Drum, Airpower and Russian Partisan Warfare, USAF Historical Studies No. $1 \overline{77, \text { Maxwell }}$ AFB, Alabama: USAF Historical Division, RSI, March 1962. 
As is always the case when large air forces are to be committed, an important and, in fact, decisive requirement was the timely establishment and development of a properly functioning communications network, a system so vital for the flexible and speedy control of operational units and, thus, for the establishment of conditions conducive to success. Alternate wire, radio, and radio-beam channels had to be established so that if one medium of communication failed, reports and orders could still be transmitted between the various Luftwaffe and Army command staffs. The radio intercept and aircraft warning services were expanded, since experience had shown that these organizations often furnished the necessary data for the successful and effective commitment of air and flak units. In view of the exceptionally heavy concentration of German flying units in a small area and the crowded condition of each airfield, radio intercept and air reconnaissance units had especially heavy responsibilities to keep Luftwaffe commands apprised of the presence of hostile air forces.

Pursuant to orders, the I Flak Corps assumed responsibility for the antiaircraft defenses in the southern area, particularly the airfields around Kharkov, but also for the defense of forward airfields in the near front areas, where it deployed many light and heavy flak batteries. The 10th Flak Brigade was committed in the Second Army Zone, with main emphasis around Konotop. The German Gommand was gravely concerned over the increasing frequency of Soviet night air attacks in German rear areas, where so many good targets were to be found, including rail and road supply routes and numerous depots crowded with supplies for the impending operation. 38

Strong Soviet air units flew repeatedly into the Orel and Kharkov areas. Since the German night fighter service had downed only a few Russian planes of the large number which were able to penetrate the area, the Luftwaffe clearly had to reinforce its night fighter forces for Operation ZITADELLE.

After discussing the matter with the Chief of the Night Fighter Arm (General der Flieger Josef Kammhuber), it was agreed that five of the existing nine night fighter flights should be assigned, two from the Berlin area and three from the Western Theater of Operations. In June 1943, after approval of this recommendation by the Commander in Chief of the Luftwaffe, additional night fighter units were committed in the Orel sector, and periodically in the Kharkov sector as well. These operations were controlled by radar mounted on a railway train. 
On the evening of 4 July the last air units earmarked for participation in the attack arrived at their assigned tactical airfields. For reasons of security and deception they had been held at rear area airfields as long as possible, with only the more important ground personnel and several key officers arriving earlier for orientation on their coming missions and for making necessary preparations. That day all unit commanders attended a situation conference at 1st Air Division Headquarters, where they were told that the results achieved in the initial air attacks would decisively influence the Army's attempt to penetrate the Soviet front. Every crew was to be thoroughly imbued with the vital importance of its specific mission. Furthermore, they were told that the relatively weak German ground units had to rely completely upon their air support and that they counted upon Luftwaffe airmen to make a supreme effort.

By nightfall of the 4th, the VIII Aix Corps was ready for action with about 1, 100 aircraft, as was the 1st Air Division with about 730 aircraft, making a total of 1,830 operational aircraft available for employment in ZITADELLE.

\section{The Last German Offensive in the Eastern Theater of Operations*}

According to plan, the forces of the German armies (Army Force Kempf, Fourth Panzer Army, and Ninth Army) jumped off to the attack. Large numbers of Luftwaffe flak units were added to the conventional artillery to participate in opening barrages. About 100 heavy flak guns $(8,8-\mathrm{cm})$ participated with the northern attack forces alone. 39

Units of the 1st Air Division took off on their first attack missions on 5 July at 0330 hours. While units of the VIII Air Corps were taking off for their respective targets, reports came in from the aircraft warning service and from Freya radar unitst that very powerful Soviet air formations were approaching Kharkov. If this enemy force intended to attack the five overcrowded German airfields and if it should arrive while the

*Eaifor ${ }^{\top} 5$ Note: For additional details on the operations of Army Group Center see Appendix 20, original German draft of this study, Karlsruhe Document Collection, and for details on the air effort see Appendices 21 and 22 of this draft. See also Manstein, Lost Victories, p. 497 . See also Map No. 9.

tEditor's Note: The "Freya" radar unit was an aircraft warning and fighter direction device with an altitude searching range of about 5 miles and a horizontal searching range of 75 miles. It could only traverse $36^{\circ}$. See $F / X$, Karlsruhe Document Collection. 
German bombers were still taking off or in the process of assembling in the air, there was a grave danger that the first massed attack of the VIII Air Corps for ZITADELLE would be broken up in its initial stages or, at least, seriously hampered. This would, of course, materially weaken the air support which was planned for the ground forces' opening attack.

Alerted by these reports, all of the German fighters stationed at Kharkoy and all of those at airfields near the front southwest of Belgorod took off immediately, not following their own bombers as had been planned, but flying directly to meet the incoming enemy formations. As the Russian squadrons approached the target airfields, Messerschmidt (Bf) 109's, coming at them out of the grayish haze of the early dawn, struck them in alternating waves in a well-directed attack. In these encounters German pilots achieved exceptional results in enemy planes shot down, while the Russians, rigidly employing their usual obstinant and inflexible tactics, continued steadfastly on their set course. In so doing they lost most of their aircraft. The battles, which were taking place at great height, could be seen clear across the skies. * At those altitudes German defense forces had an indisputable advantage. It was a mass aerial engagement such as is seldom seen, with burning and crashing Soviet bombers and their escorts falling to the ground almost everywhere, Generaloberst Jeschonnek, Chief of the Luftwaffe General Staff, happened to be at the advanced command post of the VIII Air Corps at the time, and was able to personally witness this Soviet debacle.

Flak artillery units also took their toll of the incoming Soviet planes. Without regard for their own fighters, light and heavy flak batteries opened fire on the approaching formations, coming in at altitudes ranging from 7,000 to 10,000 feet, and scored a number of direct hits.

Since few of the Russian bombers reached the target areas, few bombs were dropped, and those which were dropped were released in such haste and in such a haphazard manner that few of them even came close to any airfield installations. German bombers were thus able to continue their takeoffs and to continue operations on schedule.

In the course of the air defense action, approximately 120 Soviet aircraft were shot down, while German losses, including those destroyed on the ground, were so slight that the outcome could be described as a complete victory. The timely anticipation of the Soviet air attack and the

$\$ 10,000$ feet and above. 
personal initiative exercised by fighter commanders saved the day, and gave the Wehrmacht air superiority over the entire area for the next few weeks, during which time the Russians refrained from any aggressive air activity. The Luftwaffe was therefore able to give almost full support to the ground attack (which began precisely on schedule). The rise in Luftwaffe morale was marked and remained up for a considerable period of time. 40

Before the general offensive opened, the Fourth Panzer Army was obliged to take by storm a few observation points which, in enemy hands, might have endangered the entire operation. On the next morning, $5 \mathrm{July}$ 1943 , this army drove to the north and northeast in the direction of Oboyan, Marino, Belgorod, and Polkorovka in an effort to link up with forward units of the Ninth Army driving southward from the area just south of Orel. Just ahead of the Fourth Panzer Army the VIII Air Corps' bombers attacked targets immediately behind the Soviet front, while its groundattack and dive-bomber units bombed and strafed enemy pockets of resistance, batteries, and reserves within the actual battle area. This support greatly expedited the drives of the II SS Panzer and the XXXXVIII Panzer Corps.

The area of main effort of Army Group Center (the left wing of the operation) lay to the west of the Orel-Kursk railroad line and along the general area of the line. From this area the Ninth Army was making its drive toward Kursk. The attack in this sector was supported by bombers of the 1st Air Division, which, in their first mission, attacked crowded Russian airfields around Kursk, while the division's close support units repeatedly struck flanking Soviet artillery concentrations, especially those in the Maloarkhangelsk sector, and those in the forested fringes ahead of the advancing Ninth Army. These attacks shattered the enemy positions. 41 In the first few days of battle the 1st Air Division flew an average of five or six missions daily, attacking all targets which could be found in the line of advance. It destroyed a complete armored train in the course of these operations. As always, German flyers were far more impressed by the enemy's light antiaircraft and small arms fire than by Soviet fighters, which seldom showed themselves when German bombers had a good fighter escort.

The first large numbers of Russian fighters appeared in the 1st Air Division area late in the afternoon of the first day of combat, and in the fierce fighting which ensued 110 of them were destroyed by German fighters. The German units had very slight losses of their own. This 
successful action helped to assure air superiority over the Ninth Army sector, just as the VIII Air Corps enjoyed over the Fourth Panzer Army area. 42

Air liaison officers attached to ground divisions at the points of main effort relayed again and again the Army's requests for air support at specific places, and the Luftwaffe responded by quiclely bringing such objectives under attack. These operations were enhanced by fine summer weather, which enabled all air units to fly as many as six or eight missions daily. For the next few days both the VIII Air Corps and the 1st Air Division continued to make a maximum support effort. Again and again waves of Luftwaffe planes attacked massed Soviet artillery, troop concentrations (especially tanks), antitank positions, enemy reserves approaching from deep in the Russian rear areas, and enemy logistical movements by rail and road. German air forces also attacked Russian airfields which were reported to be heavily occupied, in order to strike enemy air units before they could launch their attacks. However, the main emphasis in Luftwaffe operations was upon direct support of friendly ground forces on the actual field of battle. Although the German Command was aware of the need for attacks deep in the rear of the operational area in order to interdict the battlefield--this was to have been done largely through cutting off railroads as had been done around Kiev in 1941--the air forces available for such purposes were far too weak. $43 *$ Because of inadequate forces to carry out such diversified air missions, the heavy losses incurred in close support work, the steady decline in operability of units, and insufficient supplies received, the Luftwaffe had to exercise extremely tight control over all of its forces, even those used for flexible operations, in order to achieve power concentrations for the currently decisive sectors.

What had been feared from the outset became apparent after the first week of the attack: the replacement services could not keep pace with the aircraft attrition rate, and, in the long run, could not measure up to the tremendous replacement capabilities of the Soviet forces. 44

Red air activities increased steadily, and the Soviet air formations began to penetrate even as far as 15 miles into the German rear area to attack supply routes and airfields. f The general impression in German circles was that the Russians were always able to make up their heavy

*Because the number of operational aircraft was less in 1943 than it had been in 1941, the operations of 1943 were almost entirely confined to the front line areas.

fSee figures 23,24 , and 25 . 
losses and maintain their numerical strength through the receipt of replacement aircraft and the assignment of new personnel. Yet, wherever German fighters appeared it was usually a relatively simple matter for the Luftwaffe to achieve local air superiority and even air supremacy over the Russians, even when the odds were very great. Under the pressure of this long period of major combat, however, the technical operability of German units unavoidably began to decline. Consequently, it was impossible to prevent the Russians, with their great numerical superiority, from making periodic air strikes against German ground troops during the absence of Luftwaffe fighters. The effects achieved in these Soviet attacks were always exceedingly small, irritating though they were. The excellent functioning German radio intercept service often succeeded in intercepting take-off reports of Soviet air formations, so that the Luftwaffe could meet approaching enemy forces in time and inflict heavy losses upon them.

In this head-on encounter between the two opposing air forces in a narrow area in which there was no possibility of evasion, the advantageous features stressed in the evaluation of the Soviet air forces became more clearly evident than ever before. The Russians were quantitatively very strong, but were mediocre in quality and inadequate in development. Yet, they had learned a lot in the past years of warfare, and had come a long way from their primitive condition of 1941. The performances of some hostile air units, especially among the ground-attack forces, were quite commendable, $45 \%$

German preparations for the attack against the Kursk salient had not escaped the Russians ${ }^{1}$ notice. Exceeding their customary practice of immediately and thoroughly developing every individual position, they had built up a defense system, organized in great depth, and protected by wire entanglements and antitank obstacles. Its strongest features were the deep flanks of the bulget and the reinforcements provided by numerous armorpiercing weapons. Strong reserve forces were also held behind all threatened sectors of the front. $46+t$

General Walter Bedell Smith, General Eisenhower's Chief of Staff, declared that the Germans would again go over to the offensive on a monstrous scale, but that the Russians were prepared and had erected

*See figure 23.

fEaitor's Note: During World War II, the Russians invariably established flank defenses in great depth.

ttSee Maps Nos. 9 and 11. 
a defense system in immense depth in the sector which would probably come under attack. He also mentioned that the two Soviet army groups in the Kursk area, Army Groups Voronezh and Steppe, were establishing a complex of antitank positions, extending in places as far as 60 miles behind the main line of resistance, to halt the German tanks with massed antitank and artillery fire.

The "bag" of Kursk, where the Soviet Command (probably supported by reports from partisans and other intelligence agents) awaited the attacking German spearheads, was transformed into one gigantic field of fortifications. Russian engineers were favored in their tasks by the heavily forested terrain, dissected in many places by numerous gorges. Villages became fortified strongpoints, one antitank and artillery obstacle following the other, and the whole system was further strengthened by mine fields, antitank ditches, tank traps, batteries of dug-in flame throwers and dug-in tanks. Behind these positions tactical and strategic reserves were held ready--there were entire divisions of artillery and tank corps in abundance-. many of them equipped with American materiel, including General Lee tanks, 47 \%

In spite of strong air support for ZITADELLE, German attack forces in both northern and southern sectors of the operation made very slow progress. In the Ninth Army area, German troops in the first two days of the attack effected a breakthrough of Soviet positions about nine to ten miles in depth, and carried their advance forward on a seven-mile front until they encountered the Soviet reserve forces, which had been thrown in on 7 July near the northern part of the Kursk bulge, just ahead of the Orel salient.

In the southern wing of the attack forces, Army Force Kemp ran into a myriad of difficulties. Its XI Corps (Generalleutnant Erhard Rauss)

"Editor's Note: Medium tank (M-3) known as the "General Grant" when mounting a British turret or the "General Lee" when it had an American turret (smaller than the British type). The same chassis was used on the Canadian RAM I and II tanks. This tank was powered by a 9cylinder Wright air-cooled engine, and armed with one $37-\mathrm{mm}$. gun and two 30-cal. machine guns, See United States, War Department, Basic Field Manual, Military Intelligence: Identification of United States Armored Vehicles, January 9, 1943, Washington: U. S. Government Printing Office, 1943, pp. 20-21. USAAF, Teaching Manual for Ground Vehicle Recognition, Orlando, Florida: AA $\overline{\text { S School of Applied Tactics, }}$ Intelligence Department, 1 October 1943, Appendix I. 


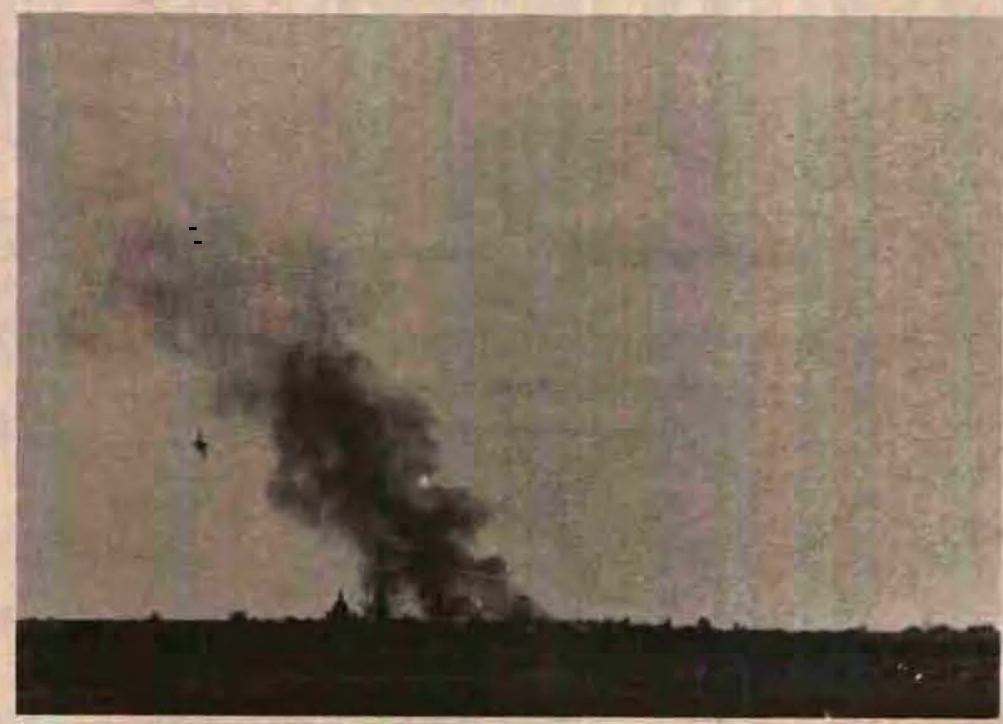

Figure 23

Soviet IL-2 "Stormoviks" attacking German airfield at Smolensk-North

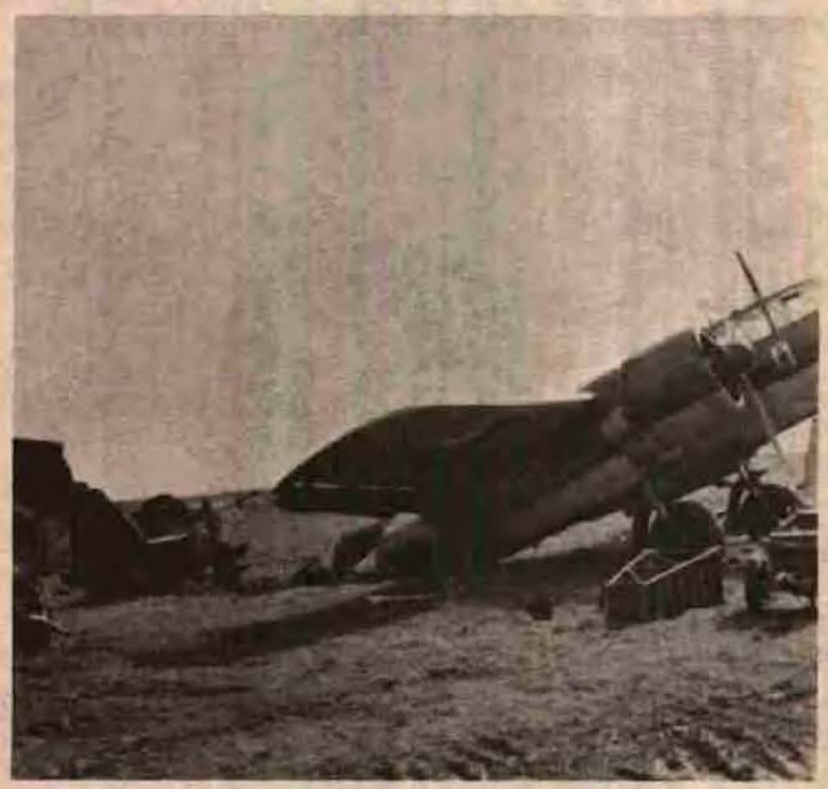

Figure 24

Damage caused by Soviet air attacks on the field at Smolensk-North 


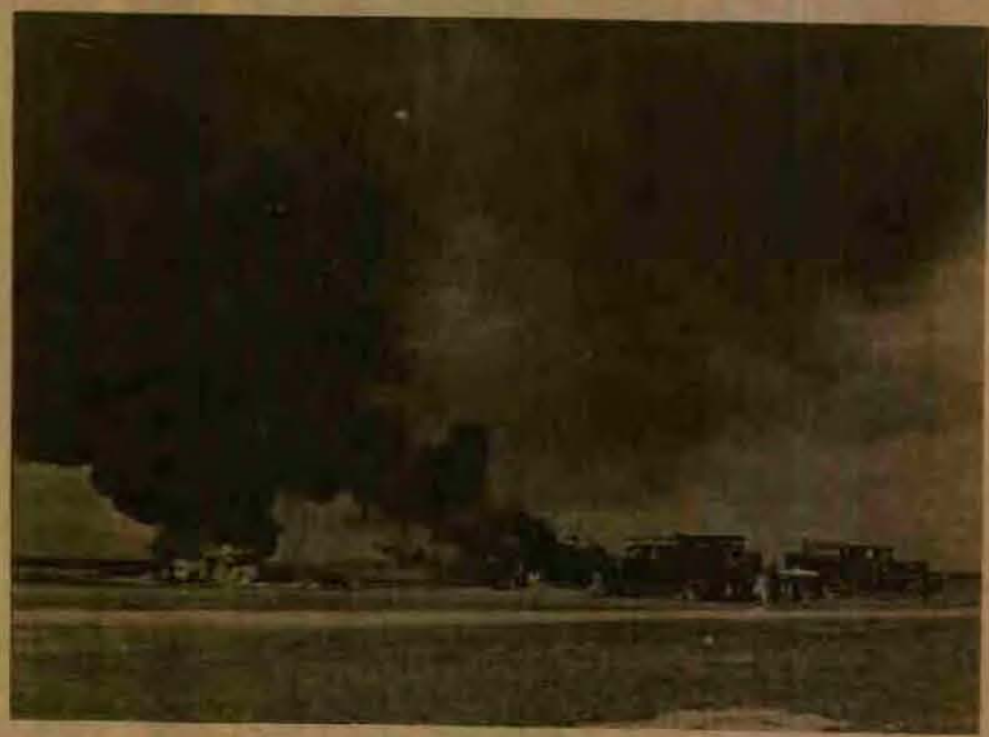

Figure 25

Damage caused by Russian air attack upon Luftwaffe base at Shatalovka, U.S.S.R., August 1943

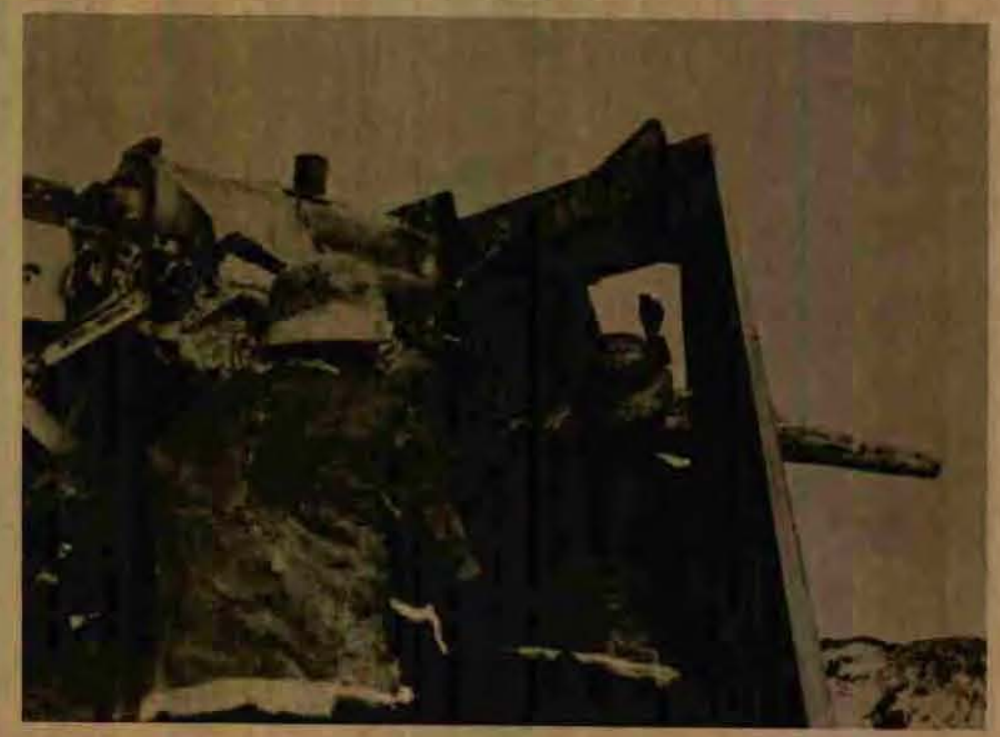

Figure 26

Flak $(8.8-\mathrm{cm}$,$) in action against ground targets$ in support of the Army 
failed to reach Korodsha as planned, and succeeded only in reaching the Koren sector, where Russian reserve forces from the area west of Volchansk were pitted against it. As a result, the XI Corps' advance devolved into a defensive battle in which German troops had to stave off sizeable Soviet armored attacks. On the left (northern) wing of Army Force Kempf, the III Panzer Corps (General der Panzertruppe Hermann Breith) made its assault across the Donets with great difficulty, and finally became stuck at a Soviet line about 11 miles northeast of the Donets River. It had become obvious that the Russians intended to hold the Kursk salient at all costs.

To the left of Army Force Kempf the SS Panzer and XXXXVIII Panzer Corps of the Fourth Panzer Army made substantial headway in the first week of the battle and, despite heavy odds, helped to break down enemy resistance in the path of the southern attack force. Exceedingly heavy losses in men and materiel were inflicted upon Soviet units by all of the attacking forces, but German units were badly battered in the process and their striking power was markedly reduced after the first four days of combat. Whenever the ground forces had taken one Soviet position they found their way barred by the next. The Wehrmacht thus had to fight its way, by costly and laborious action, through a gigantic system of positions in terrain infested with mines and packed with weapons of all types, a system which seemed to be interminable.

On 7 July the XXXXVIII Panzer Corps (Generalleutnant Otto von Knobelsdorff) broke through the second Soviet position and into the open, seven miles south of Oboyan. Immediately thereafter, however, it had to defend itself against powerful enemy attacks from the northeast, north, and west. Before it, as well as before the SS Panzer Corps (General der Waffen SS Paul Hausser), appeared strong Russian tactical reserves, three armored and one mechanized corps under the Soviet Sixty-ninth Army and the 1st Tank Army, to which were added other mobile units which were rapidly advancing from east of Kharkov. $48 \%$

The Red Army launched one counterthrust after another in steadily increasing strength, each with exceedingly heavy armored support. Thus, tanks confronted tanks in all sectors of the front. German flak artillery units committed to antitank action on the ground proved to be particularly effective, and throughout the battle these batteries served as the backbone of the Army, providing security for German troops and helping them to

*See Maps Nos. 9 and 11 . 
maintain a high level of morale. $49 *$ Without question, the remarkable suitability of the $8.8-\mathrm{cm}$ gun for repelling tank attacks and, most important of all, for knocking out tanks which had broken through the German lines, was due to its high rate of fire, high muzzle velocity and flat trajectory, and great penetrating power. The large numbers of destrayed Russian tanks were clear evidence of the repelling and destructive force of these pieces.

German antitank air units also rendered material service to the ground forces. Col. Hans-Ulrich Rudel describes the battle scene near Belgorod on 5 July when German tanks faced oncoming hordes of Soviet armor:

Large-scale tank battles raged beneath us during these operations. A scene as we had rarely seen since 1941. The tank formations stood opposed to each other in the open terrain, and in the background the opposing antitank forces had taken up positions. Some of the tanks were dug in, particularly those which had become unmaneuverable but still had their fire power. Numerically, the Russians had, as always, a towering superiority, but in point of quality the superiority of our tanks and self-propelled artillery was immediately evident. Here, for the first time, our Tiger tanks were committed in large units.f They are far superior to anything hitherto existing in the tank arm. All of our tank models are materially quicker in firing and shoot more precisely. This was due primarily to the better quality of our weapons, but the decisive factor is the better men who handled those weapons.

More dangerous to our tanks were the Soviet heavy and super-heavy antitank guns, which appeared at every important point of the battle area. Since the Russians are masters of camouflage, their antitank guns are very difficult to detect and combat.

*See figure 26.

Editor's Note: Some attention was given to the idea of reproducing the very durable Soviet T-34 tank for use a gainst the Red Army, but its aluminum Diesel engine involved certain production problems. Instead, the "Tiger" (Prkw VI), a heavy 60-ton tank was developed, outfitted with the long $8.8-\mathrm{cm}$ gun. Heavier caliber guns were rejected in favor of the fine-performing, high-velocity 88 . 
Catching sight of these numbers of tanks I remembered my plane with its cannon from the Experimental Antitank Command, which I had brought along from the Crimea. * With these gigantic target offerings of enemy tanks, an attempt on them would be possible, 50

The Soviet armor was heavily defended by antiaircraft artillery, but Rudel noted that since German panzer forces were only about 1, 500 to 2, 000 yards from the Russian tanks, he could probably crash land in friendly territory if his plane should receive a serious hit. On his first sortie Rudel destroyed four enemy tanks, and by the end of the day he had bagged a total of twelve. His fellow airmen were elated over these victories and the realization that they could play a leading role in stopping the Red Army and in saving the lives of their Army comrades.

Dive-bombers and other aircraft flying close-support missions always have a rather limited life span, since they must fly through considerable amounts of ground fire, and sometimes fires and explosions caused by their own attacks. But the main thing was that Luftwaffe leaders up through corps level now knew that they had an aerial weapon available with which they could quickly and effectively counter Soviet armored attacks.

To insure the delivery of replacement aircraft, all elements of the Experimental Antitank Squadron were instructed to immediately fly all operational aircraft, together with their crews, into the area. This was the real beginning of the operational Antitank Air Squadron, which was placed under the tactical control of Colonel Rudel. Within a few days further successes were scored by this unit. The aircraft with mounted cannons attacked enemy tanks while bombers attacked Soviet ground defenses, with some aircraft circling overhead "like a broody hen circling her chicks" to protect the antitank planes against Soviet fighter attacks. 51 These air operations were always dangerous, however, as Rudel points out:

Gradually I learned all of the details. One often learns through misfortune. We lost planes in areas with sparse ground defenses because we were circling in an area over which German and Soviet artillery were fighting a duel. Areas through which the trajectories of artillery shells passed had to be avoided; otherwise there was the chance of being shot down by accident.

*See pp. $39-41$. 
After some time the Russians succeeded in adapting themselves quite well to antitank attacks from the air. Whenever it was possible to do so, Soviet tanks towed their antiaircraft guns right up to the front. These tanks were also issued smoke cartridges with which to protect themselves by smoke screens or with which to simulate fires, so that the attacking plane would cease its attack on the assumption that the tank was on fire. Experienced air crews soon recognized these maneuvers and could no longer be deceived. A tank which is really burning will soon show the brightest flames, and to simulate such a fire would be a far too dangerous business. In many cases they would explode because the fire reached the ammunition, which is normally present in every tank, It is very unpleasant when a tank explodes immediately after being hit, and when your plane is flying over it at an altitude of only 15 to 30 feet. This happened to me twice within the first few days, when I suddenly found myself flying through a wall of flame and thought, "This is the end for you, "However, I got through entirely unscathed, even though the green camouflage paint was scorched off my plane and although fragments from the exploding tank put holes through my bird.

At times we dived to attack from the rear, at other times from the side against the steel colossi. We could not dive at too steep an angle so as to be able to descend almost to the ground without the danger of grounding. If the plane comes down too low, it is hardly possible to prevent scraping the ground, with all of its dangerous consequences, $52 \%$

Antitank air units always try to strike armored vehicles in their weakest points. Since the front side is the most heavily armored part of all tanks, tank drivers always try to offer this side to the enemy if at all possible. The flanks are most vulnerable, but the best point to attack is in the rear, for this is where the engines are located, and, because of the cooling requirements, only a thin sheet of armor plate covers this part. In fact, to increase the cooling action, these thin plates are perforated with large holes, making the target even more inviting. The rear is well

*Editor's Note: For a more detailed discussion of Soviet reactions to German air power see Generalleutnant a. D. Klaus Uebe, Russian Reactions to German Air Power in World War II, USAF Historical Studies No. 176, Maxwell AFB, Alabama: USAF Historical Division, ASI, July 1964. 
worth attacking also because there is the possibility of knocking out the engines or striking the fuel supply. Bluish exhaust vapors can easily be seen from the air while a tank is in operation. *

Other targets of opportunity presented themselves to the antitank flyers. These were Russian soldiers who rode along atop the tanks. In Rudel's words:

. . In sectors where they know us, these armored infantrymen invariably jump from the tanks the moment they sight us, even when [the tanks are] traveling at top speed. Each of them thinks he is the next one to be attacked, and Ivan prefers to face attack with firm ground under his feet. $53 t$

In many instances air units were the only forces at hand which could deliver really destructive fire to repel Soviet armored attacks. This was the case a few days after the opening of the offensive in Army Group South's (Fourth Panzer Army) sector. During that part of ZITADELIE the SS Panzer Corps in extremely heavy fighting had advanced by 8 July approximately 24 miles to a position north of Belgorod. The corps' extended right flank was exposed at this point, which was close to an extensive forested area. The advancing 6 th Panzer Division coming from the area east of Belgorod was to envelop and clean out this woods, but, before the encirclement could be accomplished, air and ground reconnaissance detected Soviet troop movements in the sector, principally in the forest. Although it was impossible to ascertain the strength of the forces involved, the area was an ideal site for the launching of an attack deep into the right flank of the Fourth Panzer Army. If If this happened, it would then be impossible for the Wehrmacht to continue its northward drive, at least until the situation in this highly vulnerable sector could be restored in its favor.

*Fuel and ammunition are normally stored along the sides of tanks, but the armor plating is also thicker there than in the rear.

Editor's Note: A further discussion of this topic is to be found in the document: OKL, Luftwaffenfuerhrungsstab Ia, Nr. 03300/43, gKdos. (Op), "Planung fuer die Panzerbekaempfung an der Ostfront im Winter 1943-44" (High Command of the Air Force, Air Force Command Staff for Operations, Top Secret, "Planning for the Combating of Armored Forces on the Eastern Front in the Winter of 1943-44't), F/V/1c, Karlsruhe Document Collection.

ttSee Maps Nos. 9 and 11. 
The German Army was alive to the threat which these Soviet troop movements presented, but it was so fully occupied with its direct combat missions--it had already committed its last reserves in this effort--that no troops could be available in the sector for counteraction if fighting should break out.

On the afternoon of 8 July 1943 the Russians opened their expected attack from the vast forested sector. 54 VIII Air Corps Headquarters had ordered a constant air surveillance of the area and was informed of this event very soon after the enemy armored, motorized, and infantry units got under way. It had prepared for such a contingency by making certain that it could send all available dive-bomber and antitank air units into action there on short notice.

Before the SS Panzer Corps or Fourth Panzer Army Headquarters even knew what was happening, and before the weak German holding force in the area could deploy for the defense, VIII Air Corps units were already on their way to battle the oncoming Soviet forces. The 4th Antitank Air Group of the 9th Dive-Bomber Wing was dispatched with its four squadrons of 16 antitank aircraft each, Henschel (Hs) 129's, twin-engine aircraft armed with a $30-\mathrm{mm}$. cannon. The group attacked the westward moving Soviet forces* which had already crossed the Donets River and the BelgorodKursk railroad line on a broad front.

Squadron after squadron attacked, returned to base (about 20 minutes away by air), reloaded and refueled, and then went back to the attack. This uninterrupted aerial assault lasted about an hour, and not only delayed, but, some places, completely stopped the Russian advance. It also compelled Soviet armored units to face about and hasten back to their jump-off positions in the forests. The Russian forces lost large numbers of tanks and motor vehicles, and suffered heavy casualties. Most of the enemy tanks and vehicles were left burning on the battlefield. It was clear that the new antitank cannons aboard the Luftwaffe's planes had great penetrating power and that they very effectively put all of the vehicles struck out of action.

Meanwhile, the noise of battle had drawn the SS Panzer Corpsit attention to the threatened flank position. Before the need arose for the corps command to take action, however, the matter had been settlled by the Luftwaffe. Some time later, when the VIII Air Corps received a

Estimated at the strength of a tank brigade with mounted infantry. Editor's Note: This unit is also known as the II SS Panzer Corps. 


\section{THIS PAGE DECLASSIFIED IAW E012958}

request from Fourth Panzer Army Headquarters for action against this Soviet offensive force, the corps was able to reply that appropriate action had already been taken. If the air corps had not made aerial reconnaissance and thereby detected the dangerous menace, and if the antitank air units had not been held ready for action, the Soviet armored drive would undoubtedly have had such a grave effect upon German ground operations that the offensive must have been broken off, perhaps for some time to come. This was a case in which the situation was restored by antitank air forces alone, without ground assistance. 55 Once again Luftwaffe units, flexibly directed, had eliminated a threat to the ground forces and thereby settled a crisis which influenced the entire operation.

On 9 July, while the battle in the Army Group South sector was still hotly contested, the Ninth Army's offensive in the northern attack sector bogged down. Faced with numerous, fresh Soviet reserves, the Ninth Army chose to consolidate its positions and to regroup, moving in new units so that it might resume the attack for the final breakthrough on the 12 th.

The lead units of the two assault wedges, the Fourth Panzer Army in the south and the Ninth Army in the north, were still about 60 miles apart when the Russians opened their decisive offensive on the 11th from the east and northeast against the projecting German Orel bulge. With vastly superior forces, the Soviet units attacked the Second Panzer Army (left wing of Army Group Center) west of Novosil, east of Bolkhov, and north of Ulyanovo, where they achieved a broad penetration, 1 mile deep, in a sector of the German lines which was held by a weak force of 1 panzer and 14 infantry divisions. 56 This was the turning point of the battle. 


\section{Chapter 4}

\section{THE AFTERMATH OF ZITADELLE}

\section{The Air-Battle Over the Orel-Salient}

On 11 July 1943 vastly superior Soviet forces attacked German positions in the Orel salient from the north, northwest, and east. These Soviet armies had cracked through the thinly manned defenses of the Second Panzer Army east of Zhizdra, Bollchov, and on either side of Novosil, and, heavily supported by tanks and ground-attack aircraft, were rapidly gaining ground, especially in the southward push in the forested tracts east of Zhizdra. The Soviet Command's obvious goal was to achieve a breakthrough to the south in the direction of Karachev in order to cut off the entire Orel salient and thereby envelop the Ninth Army and the Second Panzer Army in the general vicinity of Orel. 1 *

Meanwhile to the south the Wehrmacht's fortunes appeared brighter. The II SS Panzer Corps (Hausser) of the Fourth Panzer Army and Army Force Kempf had by this time broken through the last enemy positions into the open terrain, and were combining against the Soviet Sixty-Ninth Army. The SS Panzer Corps stood before Porolhorovka, while Army Force Kemp continued its advance toward Korodsha.

Yet, despite the propitious gains in the area of Army Group South, the threat of a repetition of Stalingrad loomed ominously in the Orel sector. To counter this grave menace, Army Group Center was compelled to employ Ninth Army troops which were regrouping for a renewed attack upon Kursk, and to send them forward as fast as possible against the Russian forces which had broken through to the north. Within a matter of hours the area of main effort had shifted from the Ninth Army's offensive sector to the defensive positions of the Second Panzer Army.

The Sixth Air Fleet went immediately into action and committed all of its available forces in support of the currently endangered sector, the area east of Zhizdra, in hope of halting or at least slowing down the enemy advance, thereby gaining time for the arrival of German ground reserves. 2 Air support for German troops in this area was not very effective and could not be effective as long as enemy units were able to

*See Map No, 10. 
find such excellent cover in local forested tracts. The only thing that could be done was to halt the daylight movement of enemy units, especially the movement of armored forces, on the few roads and paths which cut through the area. It was practically impossible, however, to detect and interdict Russian troop units moving through the woods. Repeatedly the Luftwaffe struck Soviet railheads around Sukhinichi and attacked rail installations and trains along the Kozelsk and Kaluga areas in order to interrupt the forward flow of supplies and reinforcements. Nevertheless, no noticeable results were achieved owing to the paucity of available attack forces and to the adverse weather conditions which temporarily halted all flying operations. 3

The crisis on the ground snowballed to gigantic proportions. The Ninth Army was forced to call off its attack. In an effort to improve the situation, command over the two armies in the Orel salient, the Ninth Army and the Second Panzer Army, was vested in Generaloberst Walter Model (known as The Defensive Lion of the East). * Reinforcements were hurried into the area by rail and road at top speed.

Units of the 1st Air Division, reinforced by fighter, dive-bomber, and antitank air squadrons which had hitherto been committed under the VIII Air Corps, went into action in front of the southern prong of the German attack against Kursk. This force ceaselessly attacked with bombs and small arms fire all visible Soviet forces and the forested sectors and villages in which enemy forces were suspected of hiding. $4 t$ When a powerful Russian tank force emerged from the forests into open terrain and attempted to cut the Bryansk-Orel railroad, the lifeline of German divisions fighting in the Orel salient at Khotynets, Luftwaffe units attacked and stopped its advance. 5 No German ground forces were then in the immediate area of Khotynets to halt the Soviet tank drive and protect the Bryansk-Orel rail and road routes.

All available antitank air units and fast ground-attack units made repeated low level attacks from morning until nightfall against advancing enemy forces, especially Russian tank formations. Hundreds of Soviet tanks were destroyed by aerial gunfire and the bulk of the oncoming tank

*According to Manstein, "He [Model] became increasingly the man whom Hitler assigned to restore a critical situation or to bolster a wavering line, and his performances in the execution of these missions were extraordinary." See Verlorene Siege (Lost Victories) (German edition), p. 489.

t1st Air Division Commander at this time was Generalmajor Paul Deichmann. 
corps was smashed. By the time the Soviet Command was able to launch a raid under cover of darkness, a German flak battalion had already moved into Khotynets from Karachev. For two whole days Luftwaffe forces alone denied Soviet armored units access to the Bryansk-Orel railroad, making it possible to keep the route under German control until the first Wehrmacht ground forces arrived, an achievement which was of decisive importance. 6 By its dashing and annihilating antitank attacks, the Luftwaffe destroyed most of the enemy tanks which had broken through the German lines and were directly threatening the OrelKarachev rail and road routes (a Soviet armored brigade reached the railroad line but was eliminated before it could consolidate its position). $7 *$ A teletype message from Generaloberst Model, then in command of the two German armies in the area, read:

For the first time in military history the Luftwaffe has succeeded, without support by ground forces, in annihilating a tank brigade which had broken through [the defenses].8

The steady commitment of 1st Air Division forces along the entire front of the Orel bulge sector, with its innumerable critical points, subjected the flying units to an increasingly excessive strain, resulting in a serious diminution of operational units. Supply difficulties, particularly with respect to fuel, increased at an alarming rate. At the same time, Army requests for air support multiplied because of the heavy losses sustained in antitank guns and other types of artillery. In order to avert any dissipation or dispersal of effort, and to insure that the available airpower would be properly employed in the real areas of main effort, it was unavoidable that in many instances during the frequent and widespread ground crises, the air commander sometimes had to refuse support to the hard-pressed Army forces, even when the requests were fully justified.

Because of heavy losses in antitank artillery, precisely at the time when the Russians were using more and more tanks, emphasis in the employment of German flak units shifted steadily from air defense missions to direct-fire action against incoming Soviet armor. Motorized $8,8-\mathrm{cm}$. batteries, as well as the light batteries of the 12th Flak Division, were committed in special antitanl: 3 witch positions with rear buffer positions, and often formed the inflexible, hard core of defenses around which still battle-worthy infantry elements crystallized during the fluctuating tank battles. Few similar cases can be found in the history of the

*See figure 27. 


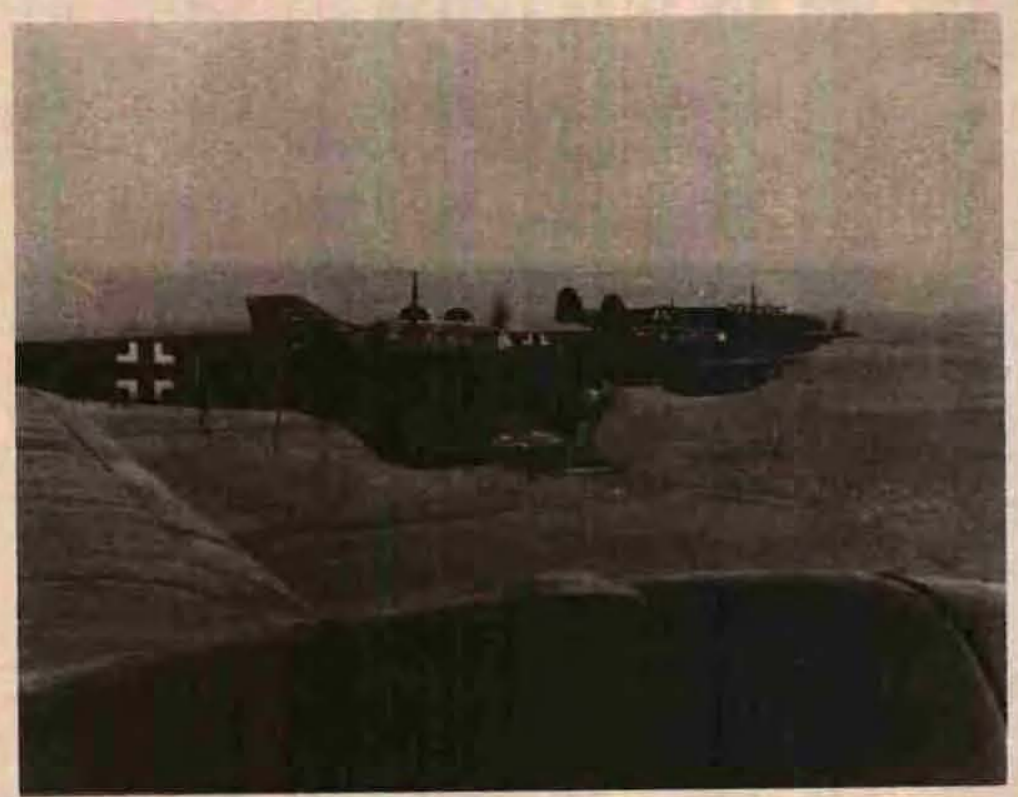

Figure 27

Luftwaffe "Destroyers" (Me-110) on an attack mission in the Orel sector 
war on the Eastern Front in which a flak division, outside of its real mission of air defense, so often became the decisive bulwark of the ground defense. 9

The commitment of the bulk of the flak artillery in antitank missions left almost no units available to provide air defense for the ground forces, the natural and original mission of the 12th Flak Division. This left the field clear for Soviet fighters and ground-attack units to operate virtually unhindered against German ground troops, which in turn naturally increased the volume of requests for fighter protection. The entire problem was a vicious circle resulting from the compulsory but illogical use of airpower and a general inadequacy of available air forces.

On 13 July, at a time when the battle for Kursk was approaching its climax and Army Group South was possibly on the brink of a successful conclusion of its operations, Hitler ordered von Kluge and von Manstein to his headquarters for a top-level conference, * There the army commanders were told that the Fuehrer was vexed over the Allied invasion of Sicily on $10 \mathrm{July}$, and by the mediocre fighting which had been done by the Italians. Furthermore, he feared that landings might be imminent in the Balkans or on the Italian mainland. Because of this, Hitler desired that forces from the Eastern Front be redeployed as soon as practicable to the Mediterranean Theater of Operations. ZITADELLE was to be discontinued. $10 t$

In the meantime Soviet armies continued to exert pressure against Army Groups Center, South, and "A." On 17 July enemy forces attacked along the Mius-Donets Front against the Sixth Army and the First Panzer Army as had been expected. Although only local successes were achieved, the threat was clear, which allowed the army group commander to retain for a somewhat longer period the SS Panzer Corps and the 24th Panzer Corps, bath of which had been earmarked for redeployment to the Mediterranean Theater.

*Editor ${ }^{1} s$ Note: Hitler was reluctant to go to the Eastern Theater of Operations and more frequently ordered his commanders to leave their posts and to fly back to his headquarters in East Prussia. Because of this, he was seldom seen in the East, and fell more and more out of touch with conditions there.

fince the Russians had already committed all of their available strategic reserves in the Kursk sector, victory was almost within Manstein's grasp at this time, See Map No. 9. 
In the Orel bulge, in the Ninth Army and Second Panzer Army sectors, the Soviet forces were gaining more and more ground, and by 25 July had reached a point immediately to the east of the city of Orel. In repeated attacks strong German air forces held up the Soviet breakthrough long enough to permit the arrival of adequate ground forces to bring the enemy advance to a halt. However, the line in the Orel bend had been broken in numerous places and had become almost untenable. Crushingly outnumbered by the attacking Red armies, which had increased in the course of the battle to 82 infantry divisions, 14 tank corps, and 12 artillery divisions, besides numerous independent tank units, the German Ninth Army and Second Panzer Army were withdrawn from the Orel salient to a line called the Hagenstellung (Hagen Position) which lay across the base of the salient immediately to the east of Bryansk. 11*

On 26 July 1943 the two armies received orders to prepare to withdraw from phase line to phase line to the defensive Hagen Position, and on the evening of 31 July (pursuant to Hitler's orders) the movement began, albeit under exceedingly difficult circumstances. Days of continuous rain had turned practically all roads and paths in the Orel sector into quagmires similar to the conditions found during the mud season. 12 Nevertheless, the evacuation movement was carried out in an exemplary manner without any trace of panic.

Anticipating the withdrawal--it was the only possible solution to the situation in view of Hitler's plans and the Soviet strength--the Sixth Air Fleet as early as 18 July had commenced the removal from the sector of all nonessential materiel and other stores to more secure positions west of the Desna River. One great advantage that now became fully evident was the fact that during the preparations for ZITADEILE every effort had been made to commit only motorized combat, technical, and supply units in the Orel area. Therefore, it was possible with a supreme exertion to move out all supplies and equipment of military value in spite of the pressures of time, 13 The only supplies which were not evacuated were bombs, but these were put to practical use in the demolition of airfields, and large quantities of them were turned over to ground force units for the destruction of railroads and bridges. Nothing

*Editox ${ }^{\top} 5$ Note: The Hagen Position ran from the old main line of resistance just east of Kirov, south to just west of Zhizdra, thence to a point west of Karachev, and south to a point a few miles southwest of Dmitrov, where it again joined the old main line of resistance. The withdrawal to this line meant relinquishing an area 63 miles in depth. 
which was deemed to be of use to the Russians was left behind. * The large airfield at Orel was demolished with especial thoroughness, 14

During the evacuation to the Hagen Position, units of the 1st Air Division helped to delay the Soviet frontal pursuit by preventing enemy armored units from overtaking the withdrawing German armies. They also attacked Russian flying units in the air as well as at Soviet advance bases in order to stop or to limit the scope of Soviet air activity in the salient area. Most of the battles against attacking Russian squadrons took place over the main Orel-Bryansk evacuation route.

A few days after the Hagen movement began, the Luftwaffe shifted its area of main effort from the Second Panzer Army sector to that of the Ninth Army in the southern part of the salient (particularly the sector between Chern and the Orel-Kursk road) where Soviet forces were increasing their pressures against the German XXXXVI Corps. The southern perimeter of the front, the Kroma River sector, had to be held as long as possible to prevent attacking Soviet armies from pushing far enough to the north to link up with Red forces advancing from the north toward Khotynets, an obvious attempt to cut off the two withdrawing German armies. 15 Luftwaffe units went into action to fend off the attacks in this sector, and on 1 and 2 August destroyed approximately 150 Soviet tanks, $f$ Because of excellent air support, the hard-fighting $7 \mathrm{th}, 258 \mathrm{th}$, and 31 st Infantry Divisions, although badly outnumbered, were able to hold the lines and to prevent an enemy breakthrough. There were, of course, a number of local crises.

The decisive role played by the 1st Air Division of the Sixth Air Fleet in Operation ZMADELLE, in the bitter defensive battles in and around the city of Orel, and during the dangerous evacuation of the Orel salient, can be best judged by the following figures furnished by the Ninth Army and the Second Panzer Army:

.. the 1st Air Division tirelessly switched back and forth between the Ninth Army and the Second Panzer Army to participate in both air and ground battles, an effort which was particularly impressive. In many hours

*Prior to departure from each sector $\mathrm{Ju}-52$ units had already completed the air evacuation of as many wounded personnel as possible to the rear areas. The remainder were transported by vehicles.

tGeneral der Panzertruppe Hans von Zorn, Commander of the XXXXVI Corps, was killed by a Soviet air attack on 2 August 1943 in the course of these defensive battles. 
of the most major crisis it was this division which turned the scales. In the battle of the Orel bulge its units averaged 5 to 6 missions per day and flew a total of 37,421 missions, achieving 1,733 aerial victories, of which 1,671 were accomplished by fighters alone, with a loss of only 64 German aircraft. In addition to this, Luftwaffe units put out of action more than 1, 100 tanks, 1,300 trucks and tracked vehicles, and numerous artillery batteries. The division delivered more than 20,000 tons of bombs on Soviet targets, thereby inflicting heavy casualties and heavy losses in railway rolling stock and supplies. 16

Complementing the flying units of the 1st Air Division were the batteries of the 12th Flak Division, which brought down 383 Soviet aircraft and two anchored balloons, destroyed 229 Soviet tanks, a large number of fortified positions, heavy weapons, and vehicles, and inflicted heavy personnel losses on Russian units while repelling numerous attacks. 17

German operations were hampered by additional factors besides the normal military activities of the enemy. At the most crucial moment, while the battle was being bitterly fought all along the front of the two withdrawing armies and while badly weakened German divisions were clinging desperately to their ground in order to carry out an orderly evacuation of the salient, Russian partisan groups hiding in the deep forests in the rear of Army Group Center went into action.

In army and army group Communication Zones, primarily in the general area of Mogilev and the rear area of the Third Panzer Army, partisans set off during the night of 2 August about 5, 000 demolition charges, destroying 30 miles of rails and interrupting rail traffic in the demolished sections for periods ranging from 24 to 48 hours. The several German commands were seriously concerned and wondered whether this was only the beginning of partisan operations on a much larger scale. According to Karlheinrich Rieker, the German aviation writer, it was well known that the partisan bands were large enough and well enough equipped to carry out such operations, which could have made it practically impossible for the withdrawing German armies to have mastered their difficulties in the Orel salient. However, after setting off a smaller number of charges $(1,763)$ on the following night, at a moment when the entire supply system was seriously endangered, the increased partisan activities ceased as suddenly as they had begun. This was just another of the many unsolved riddles of the Eastern Theater of Operations, 18 
The Russians opened their expected major assault against the XXXXVI Corps front on 5 August, using more than 200 tanks and powerful infantry units. The immediate objective seemed to be Kromy, where Ninth Army troops had performed so well in evacuating a large ammunition dump, the loss of which would have been a severe blow to the Wehrmacht. * For two days the heaviest sort of fighting raged in the Kromy sector, especially along the front of the 258th Infantry Division, which withstood 15 major attacks. Yet the line held and the Soviet plan to encircle the two armies was frustrated. Much of the success was due to the outstanding support given by the 1 st Air Division.

Meanwhile the city of Orel was evacuated on 5 August, after the Second Panzer Army had moved out 53,000 tons of materiel and 20,000 wounded men, and after it had demolished all bridges and military installations of importance in its sector. While this was being accomplished, however, the Soviet Command regrouped its armored forces for another assault, and on the following day caused another severe crisis, this time west of Uzskoye, where they tried to break through that portion of the front (northern) held by Panzer Force Harpe. $\downarrow$ Within two days the problem was mastered through stubborn fighting, a shortening of the lines, and by shifting personnel quickly to the endangered area.

Sixth Air Fleet units had been successfully redeployed to airfields back of the new main line of resistance. The evacuation of these squadrons had gone smoothly and with little enemy air interference. Soviet air forces made unexpected attacks upon withdrawing German troops and the important traffic center of Bryansk, through which so many of the evacuating units had to move. These hostile air strikes, particularly those against Bryansk, had little effect upon the overall operation, and Russian flyers made no attacks west of the Desna River. The failure of the Soviet Air Command to strike withdrawing German air units and to make a concentrated effort against Bryansk was a serious shortcoming, and one which had much to do with the success of the German withdrawal. For the Russians it was a rare opportunity lost. 19

By 9 August the German front had been safely pulled back to a line running roughly north and south of Khotynets. At the southern end of this

*See Map No. 11 .

tCommanded by General der Panzertruppe Josef Harpe, who later commanded the Ninth Army. 
line Soviet forces were still engaged in an attempt to turn the German flank or effect a breakthrough in the Dmitrovsk area, which was held by the 72 nd Infantry Division backed by a combat reserve of the 31 st Infantry Division. * The attack had begun in this sector on 8 August, and although the Russians employed all of their available forces in the area, the 72 nd Division stood as "solid as iron." Red Army units made their last attack on 10 August, an assault which was repulsed with heavy losses. Thereafter the German evacuation movement proceeded smoothly according to plan.

The last phase of the Hagen operation began on 13 August and was virtually completed within three days. Pursuing Soviet armies still tried to break through, and were especially active in frontal engagements on both sides of Karachev. As the German lines became shorter and straighter, however, the defensive power also increased, and for a time the Russians seemed to be unaware that the two armies had reached the final evacuation position, the Hagen Position. All enemy attacks were repulsed as the positions were strengthened and consolidated. By 26 August German units were ready for the expected new large-scale Soviet offensive, 20 The Sixth Air Fleet then gave its units a brief respite for rest and rehabilitation, and by September had its units at their bases ready for new combat missions.

\section{The Battles of Army Group Center in the Antumn and Winter of $1943-44$ f}

The next Russian assaults followed the stereotyped pattern adopted by the Soviet Command in the winter of 1942-43; that is, as soon as they had achieved the collapse of one sector of the front or compelled German forces to withdraw in that area, they would shift their point of main effort to the neighboring sector, thus endeavoring to break up one part of the front after another along the entire line. 21 In accordance with this pattern, once the Germans had abandoned the Orel Salient, the Russians immediately shifted their attack to the next German army to the north, the Fourth Army

*See Maps Nos. 11 and 12.

fEditor's Note: For the sake of continuity, this section has been deliberately inserted here rather than as a separate, subsequent chapter. The withdrawal from the Orel area is, of course, related to the later German retirement behind the Dnepr River. For this cause-and-effect relationship see the section entitled "Air Support During the Withdrawal Behind the Dnepr River, " p. 119. 
(Generaloberst Gotthard Heinrici), situated in the area west and southwest of Vyazma. Other strong enemy forces attacked in the Third Panzer Army sector in the Belyy sector. Although local withdrawals became necessary, Wehrmacht forces succeeded in preventing breakthroughs in the direction of Smolensk (Minsk-Orsha-Smolensk main highway [Rollbhan]) and Roslavl (the southern main highway artery), which were assumed to be the strategic objectives of the Soviet Command.

The Sixth Air Fleet operated continuously in support of the hardpressed ground forces in these areas. In the northern sector of Combat Zone Center the newly established 4th Air Division was instructed to support the defensive action of the Fourth Army and the Third Panzer Army east and north of Smolensk." In the southern sector the 1st Air Division (Generalmajor Paul Deichmann), $f$ which had given such a good account of itself in the Orel salient, was ordered to support the Second and Ninth Armies in the Mosyr-Gomel-Bobruysk area. 22

The Sixth Air Fleet concentrated the various units according to the situation in the current area of main effort, and assigned them to one or the other of the two air divisions. The most critical area was in the Second Army sector, on the southern flank of Army Group Center. With its lines breached at a number of points, the Second Army was compelled in late August and early September to withdraw behind the Desna River and later behind the Dnepr and Sozh Rivers under exceedingly heavy enemy pressure. For a time the army maintained a bridgehead at Gomel, but there was a wide gap separating it from the northern wing of Army Group South (Fourth Panzer Army) which the army was unable to close with the forces at its disposal.

Immediately to the north of the Second Army, the Ninth Army (and with it the Second Panzer Army) was also compelled to withdraw its right (southern) flank across the Desna River to maintain contact with the Second

*The 4th Air Division was established in Smolensk at the end of July 1943. Its headquarters were initially in Smolensk, later at Kamari, southwest of Vitebsk, and, after the Soviet breakthrough, at Orsha. It was under the command of Generalmajor Hermann Plocher and later of Generalmajor Franz Reuss. See figures 28 and 29.

fFrom December 1943 this unit was under the command of Generalmajor Robert Fuchs. See figure 30. For General Deichmann's role in the USAF Historical Division's German Air Force Monograph Project, see the Foreword of this study. 


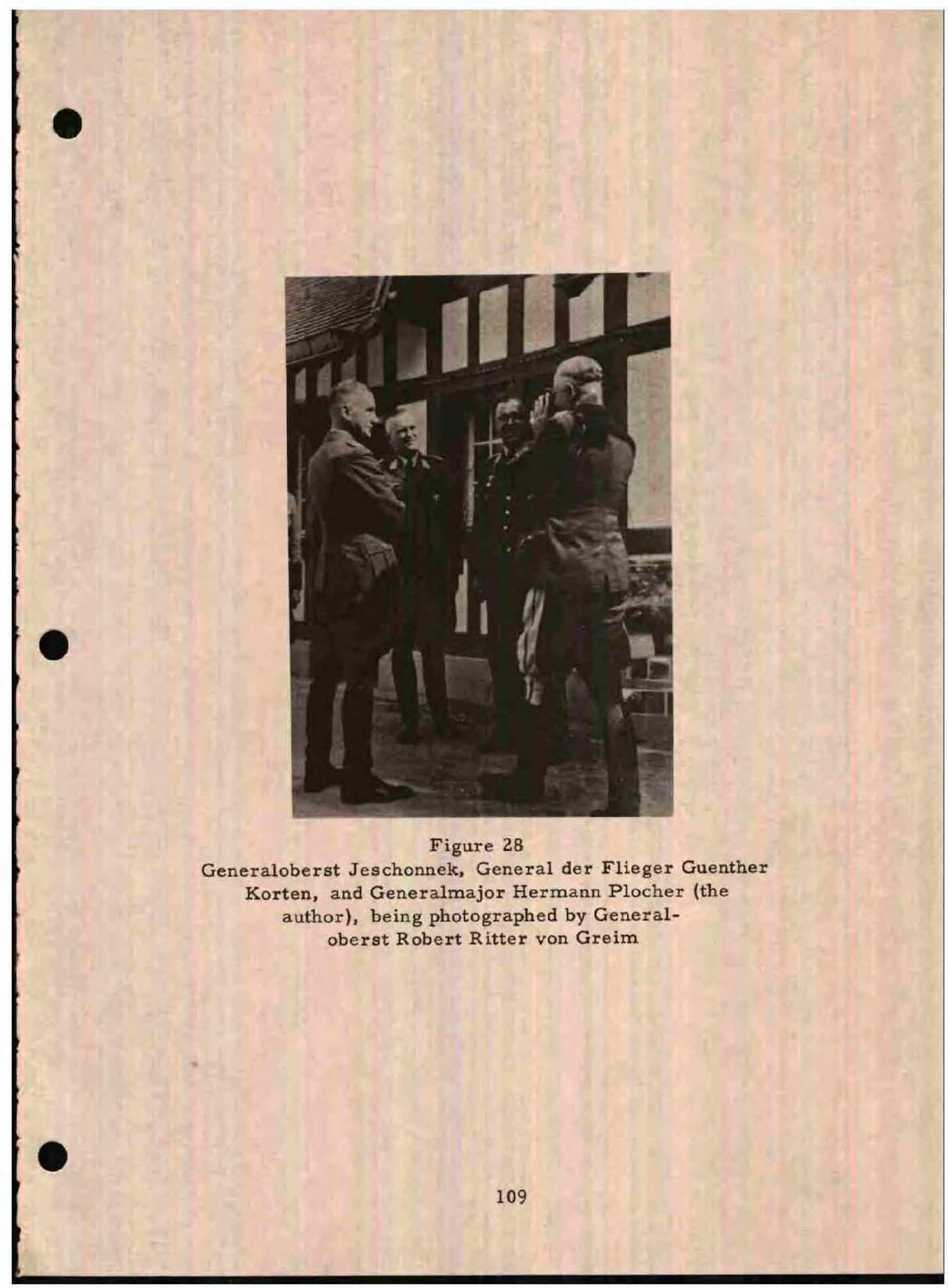




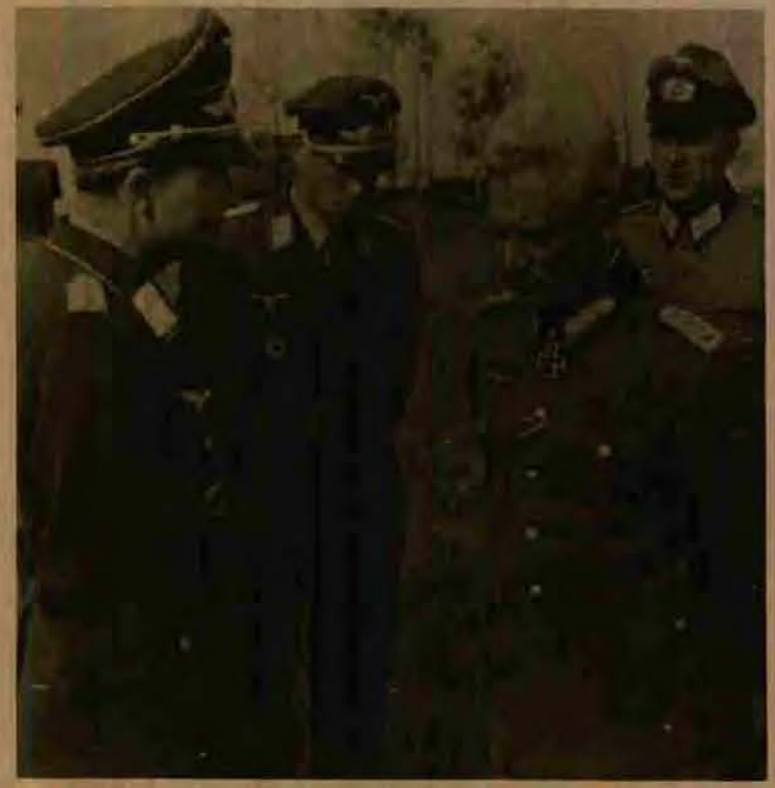

Figure 29

Generalmajor Franz Reuss (left) of the Luftwaffe conferring about an air logistical operation with

General der Artillerie Robert Martinek 
Army. The Ninth Army still held Bryansk, however, and its northern flank was still to the east of Roslavl. *

To maintain a cohesive front and to release reserves for use in critical areas, Army Group Center ordered a large-scale withdrawal along the entire front to positions extending generally from 30 miles west of Chernigov along the Sozh River, through Lenino to Rudnya, east of Vitebsk, to approximately 15 miles southeast of Nevel. This withdrawal was to be carried out in a series of retrograde movements taking about five weeks to complete, but Soviet pressures forced the army group to complete its withdrawals more quickly than planned.

As was always the case, the Sixth Air Fleet assisted the withdrawing ground forces by supporting the delaying actions by day and by making systematic harassing night raids against Soviet rail and road movements of supplies and replacements bound for the front areas. Bryansk was evacuated on 17 September and Smolensk and Roslavl on the 24th. Despite heavy Soviet pressure all along the front, the armies of Army Group Center were able by 1 October to reach their objectives and reestablish themselves in their new positions.

The Russians achieved a breakthrough at only one point, Lenino, where one of their cavalry corps drove into the German rear before it was halted and almost completely annihilated by German security forces and local reserves, with support from air units. The general area, however, remained a sector of concern to the army group. The German side, with its hopelessly inadequate screening forces, barely managed to hold back the enemy advance, while Soviet units steadily increased the pace of their buildup in the penetration area.

On 6 October enemy forces broke through in the boundary area between Army Groups Center and North, east of Nevel, and advanced beyond Gorodok and Dretun. Only very weak German forces, consisting of security and police units, could be sent into action against the rapidly advancing Russians, who were extending the front northward against the Sixteenth Army of Army Group North, and west and south against the Third Panzer Army. This advance was brought to a halt, by a great effort on the part of the German troops, along a wide arc running from north of Velikiye Luki west and southwest to the area west of Nevel and Dretun, southward nearly to the Dvina River southwest of Gorodok, thence eastward to the old line just north of Vitebsk. $f$

*See Maps Nos, 11 and 12.

tSee Chapter 3, pp. 51-53. 


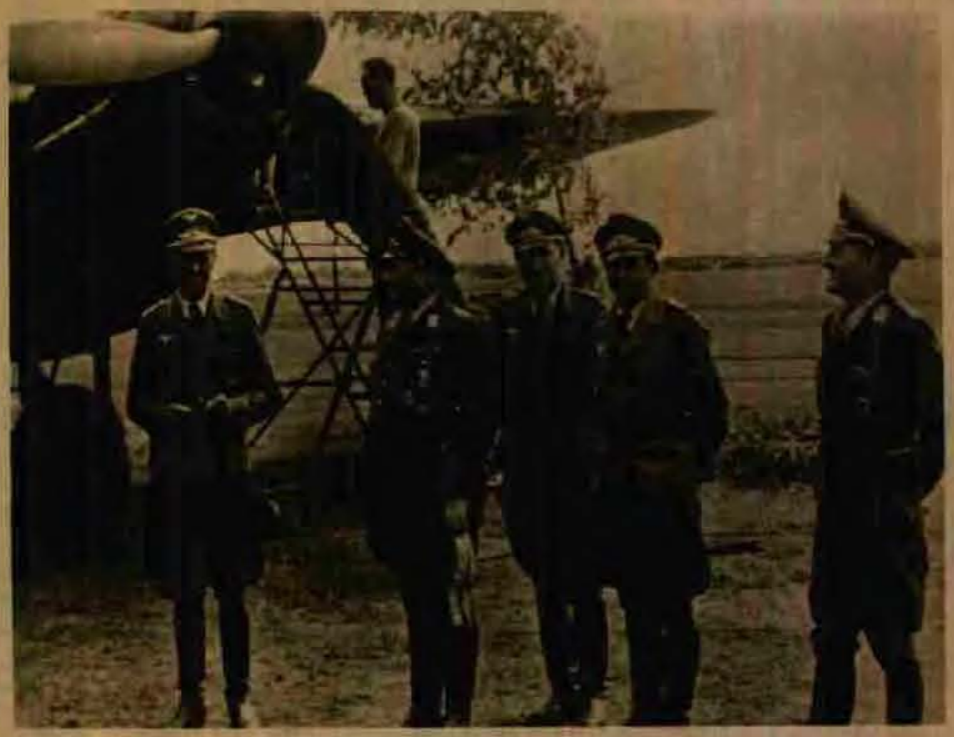

\section{Figure 30}

General der Flieger Paul Deichmann visiting the Eastern Front, 1943. L. to R.: Capt. Walter v. Kruska, 3rd Gp, 4th Bomber Wg; General Deichmann; Capt. N. Just, 4th Bomber W ; Ist Lt. Dr. Herbert Klein Ordnance Off.; Capt. Ernst Goepel, Cdr., 1st Gp, 4th Bomber Wg 


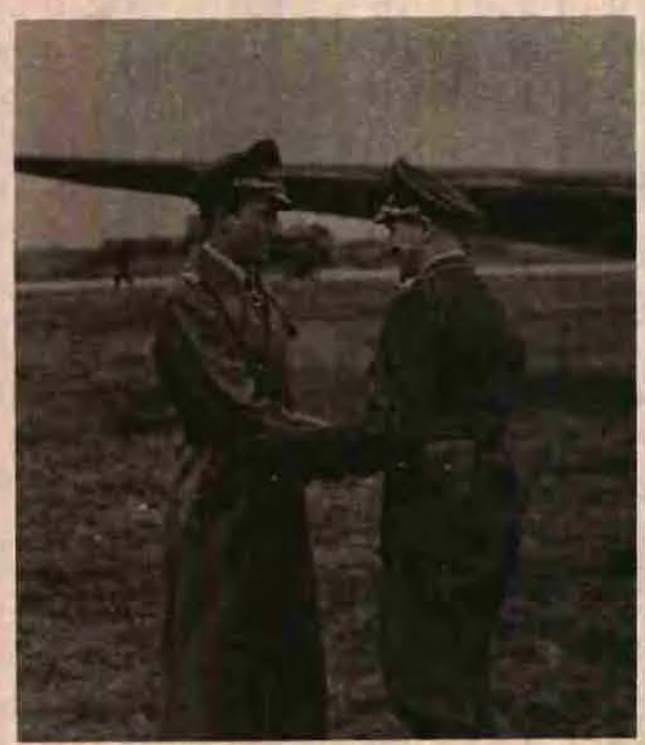

Figure 31

Capt. Walter Nowotny, German ace with over 200 aerial victories, being congratulated on his achievement, Eastern Front, 1943 
Red Army forces did not achieve a strategic breakthrough, although this should have been possible in view of the meager forces the defenders then had available. Heavily engaged in battle with Army Group South, the Soviet Command apparently did not have sufficient forces available for more extensive breakthrough operations against Army Group Center.

In the first half of October German Air Force units in the area concentrated mainly upon the Nevel sector, particularly in providing direct support for the II Luftwaffe Field Corps, which was under attack by greatly superior Soviet forces in the area between Vitebsk and Nevel. * In this crucial period even the He-111 bomber units flew close-support missions, bombing targets on the actual battlefield just ahead of the German lines. This was possible because of the presence of conspicuous and easily memorized terrain features, which practically excluded the possibility of false orientation and, therefore, faulty bombing.

From time to time it became necessary to shift the emphasis in air operations to the northern flank of the Fourth Army because of repeated Soviet attacks. The Russians, in four unsuccessful major breakthrough attacks on either side of the Smolensk-Orsha Rollbahn, tried to fight their way through the north flank of the Fourth Army to Orsha. In each of these attacks, some of which lasted as long as seven days, they committed a tremendously superior number of divisions and massed artillery units. With a gallant effort the Fourth Army beat off these attacks (which occurred late in October, in the first and the last part of November, and in early December) with only slight losses of ground, while it inflicted very heavy casualties upon the attacking enemy force. 23

\section{Air Operations in Combat Zone Center, Antumn-Winter 1943-44}

The Intelligence Branch, Office of the Commander in Chief of the Luftwaffe, reported that on 10 October 1943, 960 aircraft were concentrated in support of the Third Panzer Army. Of this number, 496 bombers, dive-bombers, and ground-attack aircraft attacked Soviet troop concentrations, tanks, and artillery positions in the Nevel area, destroying a number of tanks and artillery pieces, and striking ammunition and fuel depots, while 218 bombers and harassing aircraft attacked partisan groups southeast of Daugavpils, north of Borisov, north of Minsk, and southeast

*See figure 31 , See Map No, 11 . 
of Bialystok. That night, 88 aircraft concentrated for support missions in front of the Third Panzer Army. A total of 52 bombers were dispatched in this effort, 38 of which attacked the rail depot at Velikiye Luki, damaging 7 railway trains and causing a number of fires. Twelve other aircraft attacked road traffic in the Velikiye Luki-Nevel area, while a thirteenth struck the airfields at Smolensk and Yukhnov, setting one sizeable fire at the latter field. 24

On the following day, 747 aircraft were prepared for operations in support of the Third Panzer Army. A force of 552 bombers, dive-bombers, ground-attack, and fighter-bomber aircraft attacked Soviet concentrations northwest of Chernigov, in the Nevel penetration area, and partisan bands in the Minsk a rea and southeast of Brest-Litovsk. After dark 114 aircraft concentrated for night missions in the Third Panzer Army area. Eighty of these (bombers and harassing aircraft) were committed against the partisans north of Minsk, against the Smolensk airfield, where a number of fires were observed, against the Velikiye Luki-Toropets and Velikiye Luki-R zhev railroad lines, where they destroyed a number of trains and locomotives, and against Soviet forces concentrating in the Nevel penetration area. 25

A force of 908 aircraft was concentrated for action on 12 October and assigned to missions in the boundary area between the Fourth Army and the Third Panzer Army. Of this number, 488 bombers, dive-bombers, ground-attack, and antitank aircraft were dispatched against enemy targets in the Lyubavichi, Propoysk, Orsha, and Nevel areas, where they destroyed a large number of tanks, guns, motor and animal-drawn vehicles, and equipment. More than a hundred bomber and harassing aircraft attacked designated targets in the Baranovichi area, the area southwest of Mogilev, the Okulovo area, and the area west of Nevel. During the night, 81 aircraft were sent out in support of the Third Panzer Army $(61$ of them attacking targets along the Rzhev-Velikiye Luki and Toropets-Velikiye Luki railroad lines) and against Soviet forces in the Nevel area. Other attacks were carried out in the Smolensk-Serpukhov area and against partisan groups in the areas south of Mogilev and north of Minsk. 26

On the 13th of October, 829 aircraft were designated for action in front of the left flank of the Fourth Army, 519 of them being committed northeast of Gomel, east of Orsha, and in the Nevel penetration area. One bridge, 36 tanks, and several gun positions were destroyed. On that day 58 bomber, harassing, and reconnaissance aircraft carried out attacks against partisan bands in the areas west of Pinsk, north of Minsk, around 
Barany, and south of Polotsk. * After dark 47 aircraft were committed in the general area of Combat Zone Center, without any specific sector of main concentration. About half of them attacked tactical targets west of Smolensk, troop concentrations in the Nevel area, and the RzhevVelikiye Luki and Toropets-Velikiye Luki rail lines, while the remainder attacked targets of opportunity. 27

Reports by the Intelligence Branch of the Luftwaffe showed a commitment of 722 aircraft on 14 October 1943 in support of the northern flank of the Fourth Army. Of this total, 441 bomber, dive-bomber, ground-attack, antitank, and fighter aircraft attacked troop concentrations and positions, and occupied enemy villages in the areas southwest of Chernigov, east of Mogilev, and east of Orsha, damaging or destroying numerous motor vehicles in the process. Nearly a hundred aircraft went into action that night, attacking targets in the a rea southwest of Smolensk, rail traffic on the Ostashkov-Velikiye Luki-Rzhev line and in Velikiye Luki, airfields at Serpukhov and Kaluga, and various partisan groups in the areas north of Borisov, north of Bobruysk, and north of Minsk. 28

Reports from 15 October indicated a force of 752 planes for commitment in advance of the northern wing of the Fourth Army. More than half of this force ( 379 aircraft) was committed against Soviet troop concentrations in the areas north of Chernobyl and Lyubich, south of Chaussy, east of Orsha, and around Nevel, while another 94 bombers and harassing aircraft attacked partisans in the areas northeast of Polotsk, south of Polotsk, south of Vitebsk, north of Bobruysk, and west of Nevel. On the night of 15 October 85 aircraft were committed to action without any

*Editor ${ }^{\top}$ Sote: Since conditions in the north and the south were not particularly favorable for partisan activities, Combat Zone Center remained the principal center of partisan warfare in the East. Some partisan "bands" numbered 500 men in strength, and special units had to be detached to deal with them. As Raymond I. Garthoff points out, "It is often not realized that the partisans usually lived in permanent or semipermanent camps and in most instances did not melt back to their homes after an engagement. " Soviet Military Doctrine, Glencoe, Hinois: The Free Press, 1953, p. 399. See also General der Flieger a. D. Karl Drum, Airpower and Russian Partisan Warfare, USAF Historical Studies No. 177, Maxwell A $\overline{F B}, \overline{A l a b a m a: ~ U S A F}$ Historical Division, RSI, March 1962, PP. 6-11, and U, S. Department of the Army, Rear Area Securify in Russia: The Soviet Second Front Behind the German Lines, DA Pam. No. 20-240, Washington: OCM $\overline{\mathrm{H}}$, EUCOM Historical Division, July 1951. 
specific main area of concentration. This force attacked tactical targets northeast of Orsha, at Serpukhov, Kaluga, and Yukhnov, the RzhevVelikiye Luki and Velikiye Luki-Toropets railroad lines, and partisan "bands" in the forested tracts southeast of Minsk and northwest of Borisov. Seven Soviet railway trains were also damaged in the course of these attacks. 29

These few reports reveal the extent to which available air units were utilized in Combat Zone Center in extremely close cooperation with Army Group Center and the Sixth Air Fleet, which involved constantly changing areas of main effort and almost exclusive assignment to direct support roles. 30

The majority of the flak batteries assigned to the Sixth Air Fleet during the retrograde movements in the central sector in late 1943 were also committed in direct-support missions, in this case to provide fire for German ground forces. In costly battles these batteries made a considerable contribution to the overall defensive success which was finally achieved.

Worthy of special mention are the operations of the 12th Flak Division in the Gomel area and the operations of the 18th Flak Division in the battles fought on both sides of the Orsha-Smolensk highway (Rollbahn), as well as those in the Vitebsk area along the Luchessa River and on either side of the Rudnya-Vitebsk road. In this latter action, motorized battalions, including some from the 10th Flak Brigade, made decisively important contributions to the defeat of Soviet breakthrough attempts.

At the end of October, after the Luftwaffe field divisions had been transferred to Army control, III Luftwaffe Field Corps Headquarters was dissolved and the staff elements were used to reestablish the II Flak Corps Headquarters. 31* The II Flak Corps was assigned on 3 November 1943 to the Sixth Air Fleet with orders to support Army Group Center. Generalleutnant Job Oldebrecht assumed command of the corps at its headquarters in Bobruysk. 32

The II Flak Corps was comprised of the 12th Flak Division (command post at Bobruysk), which had the responsibility of supporting the Second and Ninth Armies; the 18th Flak Division (command post at Orsha),

*The original II Flak Corps had been dissolved in April 1942 . 
which was to provide support for the Fourth Army; the 10th Flak Brigade (command post at Vitebsk), which had the mission of supporting the Third Panzer Army; and the 27th Flak Division (command post at Minsk), which was responsible for the protection of the airfields, main supply areas, and similar objectives of the enemy in the German rear areas.

At the end of October deteriorating weather conditions considerably restricted air operations, and in November and December only a few days were suitable for operations in support of fighting German infantrymen. During this period Luftwaffe units carried out attacks mainly in the Nevel penetration area (Third Panzer Army sector), and around Rechitan (Second Army sector). 33*

The Luftwaffe was able to continue its successful antipartisan operations during the closing months of 1943, since the partisans had only the most meager antiaircraft defenses, and German air units could thus take advantage of periods of bad weather for low level attacks. The frequent interruption of rail traffic by partisans and the increasing impassibility of roads due to adverse weather necessitated an increase in logistical support by air. This was especially true in the case of shipments of ammunition and special weapons urgently needed by combat units. As in the past, aircraft returning from their supply missions were used for the speedy evacuation of the wounded.

In Combat Zone Center the last three months of the year 1943 were characterized by the almost ceaseless attacks launched first at one place and then another by the First and Third White Russian Army Groups. The enemy's objective was to outflank Army Group Center while simultaneously disintegrating its front by means of frontal breakthrough attacks. The flank attacks were intended to force the German army group to overextend its lines, while the attacks directed at Mogilev and Orsha were designed to cut the major lateral communications forming the backbone of the German logistical network. A further, and quite obvious, intention of the Soviet Command was to contain the German forces by continuous attacks and to wear them down, while preventing any transfers to Combat Zone South, the area of main effort in the overall Soviet offensive plan. 34

*On 9 December the Luftwaffe carried out day and night attacks against Soviet troop movements in the Nevel area, and destroyed 33 enemy aircraft in the course of these operations. See Von Rohden Reports, Karlsruhe Document Collection. 
An extraordinarily large share of the credit for the individual defensive successes achieved in Combat Zone Center was due to the operations of the Sixth Air Fleet. This force, commanded by Generaloberst Ritter von Greim, supported the operations of Army Group Center, even under difficult situations. When the Sixth Air Fleet was at its maximum strength for the year (1943), it had only 3 fighter, 3 dive-bomber, and 5 bomber groups. At full strength--these units never actually reached this level--the air fleet would have represented a force of more than 300 aircraft. 35 The badly understrength but extremely active units by their tireless operations, many of which involved combat missions in widely separated areas of crisis on the same day, provided the desperate ground forces with the vital support needed to withstand the enemy attacks. This air support, indeed, helped them to master many a seemingly hopeless situation. 36

\section{Air Support During the Witharawal Behind the Dnepr River*}

On 10 July 1943, before Operation ZITADELLE was called off and the Orel salient became critically endangered, the 27 th and $53 \mathrm{rd}$ Bomber Wings and one group of the 52nd Fighter Wing had been transferred from the VIII Air Corps to the IV Air Corps behind the Mius River line. I The Fourth Air Fleet, which was unable to support Operation ZITADELLE during those days because of weather conditions, was requested to take action in the Mius-Donets River area in order to break up detected Soviet concentrations preparing for an attack, 37

After a massive heavy artillery preparation, the Russians, supported by strong air forces, launched on 17 July their expected offensive along the Mius-Donets line. In the first onslaught they achieved a deep penetration into the sectors of the Sixth Armyft (General der Infanterie Kar1 Hollidt), along the Mius River, and the First Panzer Army (Generaloberst Eberhard von Mackensen), ** holding the Donets River line to the north. Once again the Luftwaffe was the first effective means available to the German Command to halt the Soviet penetration. With the support

*Editor's Note: In the original German manuscript this section followed the Orel salient action (see footnote, p. 107).

tSee Maps Nos. 11 and 12.

ffThe Sixth Army was reconstituted after the original unit bearing this number was destroyed at Stalingrad in early 1943.

**:Son of Field Marshal August von Mackensen (officer of the "Death's Head" Hussars) who served as Adjutant-General to Kaiser Wilhelm during World War I. 
of IV Air Corps (Fourth Air Fleet) units under the command of General der Flieger Kuxt Pflugbeil, the two German armies managed by the end of July to temporarily seal off the dangerous enemy inroad. The numerous aircraft shot down were evidence of the enemy's strong reliance upon airpower, particularly fighter and ground-attack aircraft, in support of the ground operations. 38

Records of the Fourth Air Fleet describe the defensive battle along the Sixth Army front, a contest which was waged with unabated fury. After prisoner of war statements indicated that Soviet attacks were imminent in the Taganrog sector, the IV Air Corps committed strong air units to support the Army forces in the area. When the attack began on $18 \mathrm{July}$ it was countered by immediate German thrusts to clean out the enemy gains along the Mius and Donets Rivers. Air units supporting the counterattacks destroyed three and damaged several more Soviet tanks, and brought down 18 enemy aircraft. Fighters of the Royal Rumanian Air Corps shot down 17 Russian planes in advance of the Mius, and on 19 July the IV Air Corps destroyed an additional 17 enemy aircraft in the air. 39

Soviet ground forces continued their assault on $20 \mathrm{July}$, placing main emphasis in the Donets area along the front of the First Panzer Army. On that day the IV Air Corps relieved the pressures on German Army troops by sweeping the skies clear of enemy aircraft, shooting down 15 in the process. Flyers of the IV Air Corps continued their successful operations throughout the month of $\mathrm{July}_{2}$ during which time they were able to substantially increase the number of rail interdiction missions. The bulk of the IV Air Corps was committed throughout the month at the point of enemy penetration northwest of Kuybyshevo, flying more than 1,000 support sorties.

On 30 July the Sixth Army counterattacked and restored the situation in the Kuybyshevo area, reestablishing the old main line of resistance. Although this action was met by tenacious Soviet resistance, including strong tank forces, the operation was a decided success. The 16th Panzer Division, in conjunction with left flank units of the XXXIX Corps, drove ahead and captured Malopetrovskiy and Grigoryevka, while the 23rd Panzer cleaned out the Soviet forces enveloped south of Mogilskiy. These undertakings were carried out despite torrential thundershowers which hampered all ground and even air operations. Whenever possible, however, IV Air 
Corps units flew air defense and close support missions. 40 In the course of these attacks numerous Soviet tanks and aircraft were destroyed. *

With the reestablishment of the old main line of resistance in the Kuybyshevo sector the battle along the Mius River ended for the time. Nevertheless, the Second Panzer Army front on the Donets remained a source of serious concern to the German Command, $f$ On 2 August reconnaissance units detected sizeable Russian forces massing in the BalakleyaAndreyevka area, probably assembling for a renewed assault upon the left wing of Army Group South. Luftwaffe units were immediately called in--some had preceded the request--and attacked these large enemy units, inflicting heavy personnel and materiel losses upon them and destroying a number of Soviet aircraft. 41 But, despite these local successes, the initiative had passed over to the Red Army along the front of Army Group South, where a most modest assessment indicated that Russian forces outnumbered the Germans by a ratio of seven to one.

After the termination of ZITADELLE operations near Belgorod on $17 \mathrm{July}$, fighting continued in that sector. Since there was no way to conceal the withdrawal of sizeable panzer and Luftwaffe units, it was little wonder that the Russians endeavored to exploit the situation by launching a major attack of their own to the east of Kharkov in the Don River bend. Under this tremendous pressure, the forces of Army Force Kempf and the Fourth Panzer Army barely managed to hold their positions.

At this time the VIII Air Corps had under its command only the Hungarian flying division and a few German units. Yet, with what was available, it supported the defenses of the Sixth Army and the Second Panzer Army as well as it could, and rendered outstanding service in attacking Soviet crossing points along the Donets River. These bridge sites could be seen from afar by the piles of material and by the approach roads which had been cut through the swampy forest. VII Air Corps units attacked these points every day, usually in the morning, to destroy all of the landing ramps and bridge sections which had been constructed during

* Because of their great strength, Soviet forces could attack in many places at once, and they appeared to be able to replace personnel, tank, and aircraft losses almost at once.

tWhile the I Air Corps was committed in the Kuban area, the IV Air Corps and the Rumanian Air Corps were employed along the Mius River line. 
the night. * Throughout the remainder of the day VIII Air Corps squadrons were so fully occupied that they were not able to fulfill the urgent requests for air support in all of the hotly contested sectors. Sometimes no air forces were available at all for days at a time except the corps' tactical reconnaissance squadron and the Hungarian air division, since the Fourth Air Fleet had concentrated in the Mius River sector all units not fighting in the Orel area.

Units were continually shuffled back and forth. Scarcely had the situation farther to the south been stabilized than the Soviet forces would break through in some other sector of the front, which required immediate air support to restore the lines. The 77 th Dive-Bomber Wing, the only really permanent component of the VIII Air Corps, was transferred to the IV Air Corps area at Kramatorsk on $16 \mathrm{July} \mathrm{1943,} \mathrm{to} \mathrm{Stalino} \mathrm{on} 22 \mathrm{July}$, back to Kramatorsk on $25 \mathrm{July}$, to Makeyevka on $27 \mathrm{July}$, and on 3 August was returned to the VIII Air Corps at Tolokonoye because air support was most urgently needed east of Kharkov and at Belgorod. 42

On 3 August Russian forces, supported by 50 to 60 tanks and strong air forces, launched a powerful attack from the vicinity of Bogorodichnoye against the First Panzer Army and, at the same time, against the front of Army Group South west of Belgorod, held by the right wing of the Fourth Panzer Army, $f$ In the latter area, Red Army troops, supported by 200 tanks, breached the German main line of resistance on a broad front between the western reaches of the Donets River and Butovo, and, by repeated heavy blows, drove a deep wedge between the Fourth Panzer Army and Army Force Kempf to its south. This advance against the right wing of the Fourth Panzer Army was brought to a stop in a few days at a line extending approximately from Shopini, north of Belgorod, to Rakovo. In this action the VIII Air Corps played a leading role, destroying 25 tanks and 56 aircraft on the opening day of battlett and achieving excellent results on the next day against Soviet forces which had penetrated into the area south and southwest of Tomarovka, 43 During the latter encounter VIII Air Corps units destroyed

*Luftwaffe attacks at Zmiyev were a complete success. They churned up the muddy roads with bombs, making the bridge approaches impassable for Soviet troops and allowing German reserves to be transferred to the Kharkov sector.

fAt this time Army Group South consisted of the Fourth Panzer Army and Army Group Kempf, the latter of which was redesignated on 15 August 1943 as the Eighth Army.

t Seven of these planes were shot down by Hungarian pilots. 
114 enemy tanks and 67 aircraft (seven aircraft being shot down by flak artillery). 44

In the ensuing days Army Force Kempf came under heavy attack as the Russians captured the sector to the east and southeast of Belgorod. In these attacks, enemy casualties and materiel losses were enormous, but the Soviet Command never hesitated for a moment to throw new unit after new unit into the engagements, regardless of the cost in human life.

On 5 August the VIII Air Corps destroyed 26 tanks in the area between Belgorod and Tomarovka in the course of the initial Soviet assault, and by the end of the day accounted for 60 tanks and 32 aircraft. Two days later Luftwaffe flyers added another 44 Soviet tanks to the list of destroyed equipment. Yet, bright as these achievements were, the situation for Army Group South remained highly tense and critical, since months of heavy fighting and the recent subjection to the most determined enemy attacks had seriously weakened both the Fourth Panzer Army and Army Force Kempf. Moreover, there was a great danger that Red forces would be able to capture the main communication route in the area, the Belgorod-Kharkov Rollbahn, thereby enabling Soviet armored and motorized units to plunge on to Kharkov itself. It was therefore obvious that Soviet forces could not be held back for any considerable period unless the German main line of resistance drew back behind the Dnepr River. The immediate, and only logical, recourse in the sector was to pull back toward Kharkov by fighting a series of delaying actions. *

To the south, in the Donets-Mius sector, Russian forces had also attacked the front of the Sixth Army. On 4 August, after a heavy artillery preparation, strong Soviet assault units struck the Mius position and, supported by 60 tanks and numerous ground-attack aircraft, advanced on a seven-mile front from the area east of Dmitriyevka. Although this attack was pursued with great determination for about two days, the Sixth Army managed to hold its line intact, inflicting heavy casualties upon the enemy, and destroying more than 50 tanks. During these operations Rumanian air units bombed and strafed Soviet villages across the Mius River and shot down seven enemy aircraft, thus adding to the equally impressive results achieved by flak units, 45

*E ditor's $^{\prime}$ Note: During the delaying actions south of Belgorod, German forces of the XI Corps withdrew in eight successive stages, each about five miles in depth, to the Kharkov area, a masterful feat. All other units north and west of Kharkov withdrew carefully to prepared positions, losing remarkably few troops in the process. 
By 6 August the situation had worsened around Belgorod. Soviet forces had reached Bogodukhov and advanced rapidly beyond it with sizeable armored units. To avoid immediate annihilation the XI Corps of Army Force Kempf was obliged to withdraw from its position near Belgorod in the direction of Kharkov. With in two days Soviet forces had widened the breach between Fourth Panzer Army and Army Force Kempf units to 34 miles. The way to Poltava seemed to be open. It appeared that the Russians intended to push to the Dnepr River and thence to the south, thereby cutting off all German units situated just north of the Sea of Azov. The III Panzer Corps (II SS Panzer Division and 3rd Panzer Division) was ordered to the Kharkov area to prepare for a defensive stand.

While Army Force Kempf was still engaged in its desperate withdrawal operation, Soviet advance units on 9 August broke through the thin line of the XI Corps along the Rollbahn and threatened to roll up the entire corps. The corps commander then hastily organized several defense points, studded with antitank units, and took personal control at the point of main effort. In a short time the attack was brought to a halt. Crucial to the defense were fighter sweeps made by the VIII Air Corps which very soon eradicated the Soviet air support and enabled German ground forces to concentrate upon their primary defense mission. Luftwaffe flak units also rendered an invaluable service by knocking out numerous Russian tanks.

During the desperate action the 6th Panzer Division, situated on the left flank of the XI Corps, was obliged to defend a front which had shortly before been held by two divisions. Only the accurate strikes by antitank air forces of the Luftwaffe enabled it to hold its position and to turn back the approaching Soviet units. *

On 12 August an extremely tense situation developed for Army Force Kempf as the Red Army opened a heavy attack to the east and southeast of Kharkov. With the German forces in and around Kharkov threatened with encirclement, General Kempf was anxious to withdraw. Hitler, however, ordered the city to be held at all costs, presumably

Whitor's Note: Heavy personnel losses and 60 tanks destroyed were a part of the price paid by the Soviets for this attack, which was stopped cold at the Lopan River. On the following evening $(10$ August 1943) the division withdrew to prepared positions about six miles to the rear. 
because of international policy considerations. * While fighting continued around Kharkov the Red Army opened a new assault on 16 August on both sides of Izyum and Kuybyshevo. Both the First Panzer Army and the Sixth Army of Army Group "A" had great difficulty in holding their positions. Strong forces of the IV Air Corps and ground-attack units of the Rumanian Air Corps supported them in their bitter defensive battles, shooting down 29 enemy planes. 46

The Kharkov area came under attack from two directions. A strong westward assault was launched from the Chuguyev area to the east, while another powerful Soviet force moved southward toward the area east of Bogodukhov from the sector between Volchansk and Belgorod. These attacks compressed the Eighth Armyt ever more closely around the city of Kharkov. Meanwhile, fighters of the VIII Air Corps supported the defenses by destroying 14 Soviet aircraft, while flak units downed another 8 planes. 47

By 20 August the situation around Kharkov had deteriorated considerably as a result of a strong Soviet drive between Akhtyrka and Bogodukhov in the direction of Poltava. The Soviet Command had had little success in frontal assaults on the city and hoped to cut off the salient by a pincers movement across the narrowest point of the bulge, the so-called bottleneck. Fortunately for the defenders, the attack toward Poltava was blunted by a counterattack to the northeast by the XXIV Panzer Corps of the Fourth Panzer Army. Air support by the bulk of the VIII Air Corps' available forces resulted in the destruction of 32 enemy tanks, 2 armored cars, and 34 aircraft.

On this same day Red Army units attacked the Sixth Army front west of the Mius River, an operation which turned out to be costly for Soviet forces, and yielded very little in gains. IV Air Corps flying and flak forces strengthened the defense and destroyed 2 tanks and 38 aircraft. 48

*Eaitor ${ }^{T_{s}}$ Note: According to Manstein, Hitler feared that the loss of Kharkov might possibly have an adverse effect upon the official positions of Turkey and Bulgaria toward Germany. See Manstein, Lost Victories, p. 518. General der Panzertruppe Franz Werner Kempf was removed from his post on 15 August 1943 for expressing a desire to evacuate Kharkov. He was replaced immediately by General der Panzertruppe Erhard Raus, and shortly thereafter by General der Infanterie Otto Woehler. Manstein agreed with this change. tAs of 15 August 1943 the newly designated name of Army Force Kempf. 
Unfortunately for the Wehrmaeht, all of these defensive achievements were quite temporary in character, since the Russians quickly sent in fresh units and renewed their onslaughts, losing heavily in men and materiel, but giving the German forces little respite.

Units of the Fourth Air Fleet sent their forces again and again into action in support of the Army. Emphasis in these operations had to be constantly shifted in accordance with the various crises which developed, so that individual units often had to be transferred back and forth from one sector to another on very short notice. On a given day they might be operating under the IV Air Corps at the Mius River, on the next under the VIII Air Corps in the Kharkov-Poltava area in support of the Eighth Army, and on the following day in some other sector where a new and more dangerous crisis had developed,

Although seriously weakened by long and arduous weeks of combat, the remaining units of the VIII Air Corps contributed more than their share in the defensive battles of Army Group South, a contribution which required the highest degree of devotion to duty and outstanding improvisation in every aspect of military aviation.

Frequently air units which were dispatched to relieve pressures on the ground forces arrived at the latest possible moment. Actually, this made their attacks particularly effective, for the entire disposition of enemy forces could thus be clearly seen and concentrated attacks carried out. Soviet units usually assembled during the afternoon under cover of hollows, ravines, or other protective terrain features. The masses of men and equipment assembled offered excellent targets for dive-bombing attacks, which usually broke up the formation so that the enemy ground attack had to be postponed. German ground forces thus enjoyed a brief respite from fighting.

An example of this sort of Luftwaffe operation occurred when the 27 th Bomber Group, based on airfields at Uman, after returning from a bombing mission in a southern sector of the front, was dispatched late in the afternoon to strike a Soviet assembly area. Despite the strain imposed upon the aircrews by additional combat missions, it was essential to strike the target, for it was a threatening group of armored vehicles which seemed "ripe" for an attack. This large Soviet tank force had been observed just to the west of Kharkov at Olshany by General der Panzertruppe Erhard Raus, * and from all indications it seemed to be concentrating

*Briefly in command of the Eighth Army (15 August 1943) after Kempf was relieved and before General Woehler assumed command.

126 
for an attack. German ground forces in the area were far too weak to repel the expected assault, and there was a great danger that if the coming attack succeeded the line at Kharkov would be breached from the west, thereby isolating German units to the east.

All of the VIII Air Corps' units were still out on missions and could not arrive in time for the necessary action. Corps headquarters therefore contacted the commander of the bomber group by telephone and requested support, even though it had no actual command authority over this particular unit. The group commander grasped the special significance of the situation and undertook the combat mission. Having no suitable bombs at his base, he ordered his planes to load up with aerial mines. Attacking with these, the group swept the Soviet tank force, which was caught just as it was moving forward to attack, completely annihilating it. According to General Raus, the blast effect of the aerial mines was "terrific," the Soviet tanks being "blown over and their infantrymen annihilated. 149

Again and again during these anxious weeks of crisis the weakened Luftwaffe units were the only available means by which effective support could be given to the ground forces. It is therefore only natural that these ceaseless operations, many of which involved excessively frequent transfers, would result in a marked decrease in operability of both ground service and flying units, and this at a time when the ground forces' needs and requests for air support were increasing at an immense pace. Both the newly designated Eighth Army and the Fourth Panzer Army frequently made impossible requests of the VIII Air Corps; yet, all things being considered, they could often do little else since they really had no other recourse.

Although reconnaissance units were tireless in carrying out their missions to provide the necessary data for Army and Luftwaffe forces, the few available fighter units of the 52 nd Fighter Wing had a formidable task in combating the rapidly increasing number of enemy fighter and ground-attack forces, Yet, although the Soviet forces had great numerical superiority, they were never qualitatively superior in combat, a fact which could be attributed either to low training standards for Soviet flying schools, or to a healthy respect, bordering at times on outright fear, of German airmen. In any case, it was known that the Soviet Eighth Air Army, which was committed against the German Eighth Air Corps, had not yet recovered from the beating it had taken in the air battle at Kharkov on 7 July 1943. 50 At least it had failed, despite its numerical superiority and the pronounced weakness of German units, to develop into an opponent worthy of respect. 
On the ground the Soviet Command continued to commit great numbers of troops and armored equipment in combat, often losing and replacing entire units in a relatively short time. Corresponding German losses were much lighter, yet the overall effect was more serious for the Wehrmacht, since the German Command had no large pool of replacements with which it could offset the steadily rising attrition rate. This was a problem which beset every German commander on the front, and played an important role in considerations with respect to Kharkov.

Although during the course of the war the possession of the city of Kharkov had been so often and so hotly contested, Army Group South was not prepared to lose an entire army in its defense, especially in 1943. Consequently, German forces were withdrawn from the area on 22 August, a move which allowed the Eighth Army to avoid encirclement and to redeploy its forces for the reinforcement of its threatened flanks.* On this same day the southern sector of the Eastern Front was subjected to a strong enemy assault. In this crisis the First Panzer Army and Sixth Army had been able to prevent a serious breakthrough on the Donets River front, but, in withstanding these heavy attacks, the fighting power of their units had been sapped, $f$ So serious was this situation that the army group commanders requested a meeting with Hitler to discuss the possibility of some radical changes in the defensive arrangements.

On 27 August Hitler finally left his headquarters in East Prussia and came to Vinnitsa in the southwestern Ukraine to discuss matters with von Kluge and von Manstein. After carefully explaining the situation, Manstein told the Fuehrer that only two alternatives were open: (1) an immediate reinforcement of the southern front with at least 12 fresh, combat-ready divisions, or (2) to abandon the Donets River area in order to shorten the lines and permit a better utilization of manpower for the defense. At first Hitler attempted to pacify the commanders by promising to move "all available" units not urgently required by Army Groups North and Center to the southern sector. But, before such a possibility could be explored, Red Army units opened a heavy attack upon Army Group Center, tying down all of the forces in that area. Hitler then suggested that everyone take a "wait and see" attitude for the time being.

\#Editor's Note: A new, but purely provisional, front was established on 27 August for units of Army Group South, extending approximately from Kharkov to Sumy.

tThe Sixth Army, consisting of 1 panzer and 10 infantry divisions, was pitted against an enemy force of 31 infantry divisions, 2 mechanized corps, 7 tank brigades, 7 additional tank regiments with 400 tanks, and some independent battalions. 
The Soviet Command, however, gave the Wehrmacht no rest, and continued to attack in great strength, especially on the Donets-Mius front. While the Fourth Panzer Army and the Eighth Army had been able by brilliant defensive action and daring counterattacks, and with constant support by the VIII Air Corps, to maintain a reasonably cohesive front in the Poltava-Kharkov sector, the situation was more immediately threatening in the south. Here, the overwhelming pressures exerted against the Sixth Army front had led to the loss of the Mius River line, and this despite all possible support by the IV Air Corps. Consequently, the XXIX Corps, holding the right flank along the coast, was threatened with encirclement.

The Red Army's capture of Taganrog on 29 August made it clear to the German Command that the Mius position could not be regained and that the present line could not be held, * Therefore, the army group ordered the Sixth Army on 31 August to withdraw to the west behind the line known as the Tortoise Position (Schilakroetenstellung). This became the first step in the evacuation of the entire Donets area, an industrial region much desired by the Soviet Union.

On 3 September Hitler again attempted to dispel the fears and anxieties of Manstein and Kluge with respect to the ominous threats of the Red Army along their fronts by promising to reinforce the southern area with units to be withdrawn from quieter sectors, such as the area of Army Group North. These proposals were not greeted with much enthusiasm by the two army group commanders, since they regarded them as impossible to fulfill. They did, however, hope that some sort of unified command might be established to coordinate matters in the Eastern Theater of Operations. All discussions concerning the creation of a Commander in Chief East (Oberbefehlshaber Ost), comparable to the arrangement in the Mediterranean Theater, were quickly and sharply rejected by the Fuehrer.

As Manstein expected, the situation along the southern front continued to deteriorate, forcing the German Command to make a decision about a withdrawal. A meeting was arranged for the 8 th to discuss the grave issues involved. Hitler summoned not only von Kluge and Manstein, but also Field Marshal von Kleist, Commander in Chief of Army Group "A, "

*Since the Fourth Air Fleet was required to commit its forces simultaneously in the Mius River area, at Taganrog, and in the First Panzer Army sector along the Donets River, units had to be constantly shuffled from one area to another. This weakened the larger units by dissipating their power, and made control over them difficult. However, many a command crisis was mastered by excellent communication lines, which Luftwaffe signal units always managed to reestablish. 
and Generaloberst Ruoff, Commander of the Seventeenth Army. The army leaders quickly agreed that all Wehrmacht forces should be immediately withdrawn in the southern area to positions behind the Dnepr River.

Hitler issued the order on 15 September for the withdrawal of Army Group "A" (Sixth and Seventeenth Armies and Rumanian Third Army) and Army Group South (Eighth Army and First and Fourth Panzer Armies) to a line extending from Melitopol to the Dnepr River bend at Zaporozhye, and thence along the Dnepr to a point just north of Kiev. During the previous night the Seventeenth Army had already begun its evacuation of the Kuban Bridgehead. $51 *$

This retrograde movement became a continuous battle of withdrawal, with frequent delaying actions and moments of extreme crisis. The speed of the operation depended largely upon the fighting power of individual units and on favorable terrain features which could be used for defensive purposes. The Russian civil populace was evacuated during the withdrawal from an area extending eastward from the Dnepr River to a depth of about 18 miles in order to deny Soviet forces fresh sources of replacements and laborers. $f$ These civilians were nōt driven out, but were allowed to take their cattle, horses, and all moveable goods with them as long as it could be transported. These long coltumns moved westward in convoy with German combat and transport units, leaving nothing of human or material value behind for the pursuing Red Army. 52

The movement promised to be relatively simple in the Sixth Army sector, but the withdrawal of the Eighth Army and the First and Fourth

See Pp. 24-25.

tEditor's Note; It was standard Soviet practice to round up all available men in combat areas (including older men) for use in military or labor forces. Grain, cattle, and other commodities were also confiscated from the civil populace for the use of the Red Army. Because of this, some Russians began their westward treks before the Germans ordered a general withdrawal. See Manstein, Lost Victories, pp. 539540. A cardinal fault of German policy in the East was the failure to understand and to properly exploit the native population's disaffection for the Soviet regime. Excesses committed by German police and political units--these were the principal offenders--then turned the Russians away from the Wehrmacht, which they had once greeted as "Iiberators," and into the arms of the Soviet government, which, although brutish and oppressive, was at least a native oppressor. 
Panzer Armies was much more complicated. The latter three armies held a front more than 450 miles in length, behind which were only five adequate crossing points over the Dnepr. To make matters worse, because of the disposition of forces and the natural terrain features, the Eighth Army and the First Panzer Army did not dare withdraw to the west in a vertical line running north and south, but had to effect their withdrawal along a slanting line running from the northwest to the southeast. The entire operation was completed by 30 September 1943, and with more modest losses to the Wehrmacht than had been anticipated by the German Command. *

Once across the Dnepr River, German forces turned their energies to strengthening and improving the defenses by establishing field fortifications in depth. As long as mild weather prevailed, however, the river presented the greatest natural obstacle to an enemy attack. $53 \mathrm{f}$ Just as the major Russian rivers, the Don, the Volga, the Kuban, and the Terek, had influenced the conduct of operations during the German advance in 1942, so during the Wehrmacht's withdrawal in 1943 a determining factor was again the principal rivers along which defensive lines could be established, such as the Don, Mius, Seym, Donets, and Dnepr.

In the final stages of the withdrawal behind the Dnepr, rapidly pursuing Red Army units had been able at a few points to cross the river with the retreating German ground forces and to establish small bridgeheads west of the river, halfway between Dnepropetrovsk and Kremenchug, and north of Kanev to the west of Pereyslav. Owing to the lack of combat reserves, German forces in the area were unable to eliminate these small centers of enemy penetration. Although initially of minor significance, these bridgeheads were to become decisively important as staging areas for coming enemy offensives.

*200,000 wounded men were also evacuated during this operation. tEditor's Note: The strength and concentration of German forces

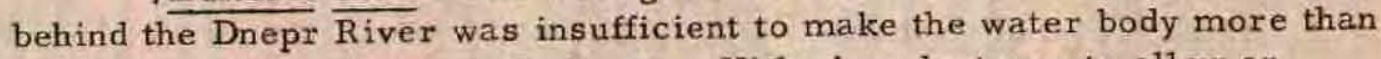
an obstacle to enemy assault forces. Hitler's reluctance to allow an earlier build-up along this line was to have dire consequences. During the winter most of the Dnepr freezes to a sufficient depth to support tanks. For a more detailed discussion of Soviet terrain see U.S. Department of the Army, Terrain Factors in the Russian Campaign, DA Pam. No. 20290, Washington: OCMH, E $\overline{\mathrm{UCO}} \overline{\mathrm{OM}}$ Histarical Division, July 1951, and Generalleutnant a. D. Hermann Plocher, The German Air Force versus Rassia, I94I, USAF Historical Studies No. 153, Maxwell AFB, Alabama: USAF Historical Division, ASI, July 1965. 
During all of the withdrawal battles the Fourth Air Fleet closely supported Army Groups "A" and South, especially the latter, sending its squadrons again and again into action against targets on the battlefield, particularly tanks. Operations of this sort became known as fire-fighting tactics and air units which carried them out were called fire brigades.* Air units of the First Air Fleet were transferred back and forth between its air corps as the ground situation and air support requirements demanded, 54 The active role played by Luftwaffe organizations in halting and delaying the pursuit of the Red Army at the Dnepr is described in the following account by Colonel Rudel:

By now it was high time to evacuate our field and we took off after setting fire to all inoperable aircraft which had to be left behind. . . We flew west-northwest by compass, After a while we flew low over a road and met heavy antiaircraft fire from a large motorized column traveling beneath us under tank escort. We dispersed and circled the vehicles. There were Soviet tanks and trucks, most of them American models, so they were obviously Russian. . . . We climbed higher and I gave the order to attack the antiaircraft guns, which had to be put out of action first so that we could have time for our low level attacks.

After silencing most of the antiaircraft guns we spread along the column and destroyed all vehicles without exception. It was darkening, and the entire road presented the appearance of a flaming serpent. . . Hardly one of them escaped and once again the Russians must have lost a considerable quantity of material. But what was that? I flew to the head of the column, to the first three or four trucks. Each of them had our flag painted on its hood. These trucks were German models, and 200 yards up the road someone was firing white signal flares, the identification signal for our own troops. It was a long time since $I$ had felt as badly as I did at that moment. . . . Had it been a German column after all? Everything was in flames. But why were we fired upon so heavily from the vehicles? How was it that the trucks had been American models? And, I had definitely seen men in brownish-green uniforms running. . . .

*Shortages of heavy weapons, especially field artillery, made Luftwaffe ground-attack forces the only available means for stopping large-scale armored attacks. 
It was already fairly dark by the time we reached base at Pavlovgrad. Not one of us said a word. We were all troubled by the same thought; had it really been a German column after all?...

Toward midnight an Army soldier arrived and my staff officer shook me out of my exceptionally restless sleep, telling me it was important. Our Army comrades wanted to express their gratitude because they had been able to escape that day because of our help. They told us how a Soviet column had caught up with their vehicles. All they could do was to run a few hundred yards up the road and take cover in a ditch from the Soviet shells. At this moment we arrived and shot up the Russians. They had taken advantage of the situation and run another 200 yards or so up the road. This took a load off my mind and my comrades and I were very happy. 55

In the course of the retrograde movements it was not long before air units were assigned individual targets, which they had to seek out and strike within a general target area. This entailed entirely different modes of operation for the air command staffs. Unit leaders at lower levels were given greater freedom of action, and no longer had to be given detailed orders. Conversely, they then required continuous and detailed orientation on the situation, including all current changes, a most essential prerequisite for successful attacks.

Each unit commander then became more or less the chief of a small tactical support command and, within certain limitations, could issue his own orders and employ his own force independently. The control of specifically combat operations was shifted to lower command levels. For the command staffs at air fleet, air corps, and air division level, the most important function during these circumstances, apart from the distribution of forces, was to insure continuous aerial surveillance of the entire area in order to obtain as precise a picture as possible of both the air and ground situation. Other important missions (in order of priority) were: (1) to arrange for the timely preparation and supply of new tactical bases; (2) to secure timely and sufficient amounts of supplies for the tactical bases already in use; (3) to arrange for the prompt establishment of command posts in the probable areas of main effort (in the light of a clear interpretation of probable developments) and, concurrently, for the rapid development of a command signal communications network to secure the control of all operations and supply movements. 
To these missions must be added that of evacuation, a particularly difficult undertaking. Owing to the general shortage of supplies, the evacuation of all equipment and supplies was especially important, and often decisive, for the operability of the units and even for the execution of missions themselves.

The evacuation of airfields was particularly difficult because of the dual requirement that airfields were to be destroyed as thoroughly as possible but would be kept in operational use up to the last possible moment. For this reason, sheds, billets, shelters, signal communication and command post installations, and similar structures were demolished first. The airfields were plowed up and mined, and only one take-off and landing runway was maintained until the moment when the planes took off to transfer to another field. Frequently this last runway was not blasted until after the last aircraft had taken off and the first shells from Soviet tanks or artillery had begun to fall in the area.

Often these last-minute demolition tasks were only possible because of defensive action by flak units which were committed to protect the airfields, After the flying units had evacuated the field, these flak units assumed a ground-defense (direct-fire) role, and maintained effective fire to halt the Russians until all demolitions were completed.

By the end of September 1943 the armies of the southern front in Russia had been safely withdrawn and established in their new main line of resistance behind the Dnepr River, and their materiel had been evacuated without serious interference over the few existing bridges. Strong flak and fighter forces then were assigned to protect the new positions, while ground force units reorganized and reestablished their forces.

\section{Luftwaffe Support in Defense of the Dnepr River Line}

German leaders correctly assumed that the Russians would allow the Wehrmacht no opportunity to rest and rehabilitate itself or to improve its defenses behind the Dnepr River. They also expected that the enemy would soon launch new major offensives, particularly in the southern areas, once he had regrouped his assault forces and brought his armies up to the desired strength through the addition of new replacements.

As was noted previously, * during the German withdrawal across the Dnepr River a Soviet force had also managed to make a crossing

*See p. 131 . 
north of Kaney and southwest of Pereyslav and to establish a small bridgehead, which was soon reinforced by eight infantry divisions and a tank corps. 56 Taking advantage of islands in the river, the Russians also crossed the river between Dnepropetrovsk and Kremenchug, where they set up a second bridgehead.

Troops in the Soviet bridgehead in the Pereyslav sector received support from strong partisan groups which had organized some time before in the area west of the Dnepr. It was during the operations connected with this bridgehead that the Red Army for the first time in the campaign (25 September 1943) committed substantial paratroop and other airborne forces with the intention of taking a tactical objective. $57 \%$ The purpose of the airborne operation was to breach the new German line along the Dnepr by an attack from the rear.

On the night of 24 September reports came in to VIII Air Corps Headquarters that a Soviet airborne operation was underway. Armed with this information, reconnaissance units took off in the first light of dawn on the 25 th to view the area. Numerous white parachutes left lying about in open territory by the Russian forces immediately revealed not only the drop zone, but also the approximate strength of the enemy force. $58 \mathrm{t}$ German reserves on their way to the front, who happened to be in the area where the first landings were made, went into action at once and very soon annihilated nearly the entire Russian airborne force. Only small remnants made good their escape into partisan-held territory.

Other large-scale airborne operations were also carried out by hostile forces during the month of September 1943. The Soviet Command launched such undertakings in the Ukraine in the strength of two brigades each at Kanev, Kiev, and Cherkassy. All of these attempts, however, ended in failure. 59

While Soviet airborne units could be quickly located and eradicated, German ground forces were manifestly too weak to breach and eliminate

*Editor's Note: The German word operativ, which is used here in the original text, can mean either strategic or tactical, and sometimes operational. While "tactical" is implied in this instance, the objective was one that had definite strategic possibilities.

7Statements concerning the strength of this force are not in agreement, but it seems clear that the unit was between two and five brigades strong. For additional details see Appendix 26, original German draft of this study. 
the two Soviet bridgeheads by counterattack, thereby clearing the entire western bank of the Dnepr of enemy troops. These points therefore remained as open abscesses along the front.

On the northern flank of the Fourth Panzer Army, along the boundary with Army Group Center, Soviet forces had also crossed the Desna River and, in early October, proceeded to establish two new bridgeheads west of the Dnepr River, one on either side of Kiev. 60 The Soviet Command then regrouped its forces, with main concentration in the sector just north of Kiev. About 10 October a night reconnaissance unit of the VIII Air Corps detected a large Soviet force east of Kiev moving from south to north. Since these vehicles were traveling with headlights on, it was easy for German observers to ascertain the size and direction of the movement. News of this regrouping movement was naturally of decisive importance to the Fourth Panzer Army, which was thus able to withdraw forces from its main defensive concentration south of Kiev for commitment elsewhere. 61

The VIII Air Corps placed main emphasis during the defensive battles raging from Kremenchug to Chernigov in the Kiev area. It supported the XXXXVIII Panzer Corps ${ }^{1}$ action against Russian units advancing from the enemy bridgehead at Pereyslav, and bombarded the bridgehead just north of Kiev. Although good results were achieved again and again, the Soviet troops always repaired their damaged bridges and approaches within a surprisingly short time.*

A bomber group based at Shitomir went into action periodically and, with the help of a Freya radar device at the base, was able to plot the precise route to the Soviet bridgehead north of Kiev. Using another Freya instrument, which was situated west of Kiev parallel to the approach route, German aircrews were able to control the time of release of their bombs and to carry out very effective harassing raids against the bridge sites. Approaching by night or above the clouds, Luftwaffe bomber units surprised the enemy with the accuracy of their attacks. 62

According to Generalmajor Hans Seidemann, commanding the VIII Air Corps, the Dnepr River was at a low stage, so that it was possible to

*Editor's Note: See Generalleutnant a.D. Klaus Uebe, Russian Reactions to German Airpower in World War II, USA F Historical Studies No. 176, Maxwell AFB, Alabama: USA Historical Division, ASI, July 1964, pp. 83-85. 
cross at some points on foot. Apparently the Russians failed to notice this fact, since they neglected to exploit these favorable conditions. However, enemy forces later proved to be extremely clever in all of their efforts to gain a foothold on the western bank. Footbridges and even larger bridges were so constructed that the tops were about a foot or two below the surface of the water. * Consequently, they were not endangered by artillery fire since they were not detected until a careful study of aerial photographs raised suspicions concerning tracks which ran to the water's edge. The Russians later built even a large railway ponton bridge, across which they moved railroad cars, either singly or in groups. There was no doubt about it, in matters involving the use and exploitation of terrain the Russians were masters, 63

German fighters gave an excellent account of themselves in every operation. Fighters of the VIII Air Corps, based on the Kiev-West airfield close behind the front lines, were extremely successful against the enemy air forces, and in the course of these frequent attacks one officer shot down 18 aircraft in a single day.t

A night harassing group, newly assigned to the VIII Air Corps during this period, also achieved very good results in its operations. The Soviet practice of moving its columns at night with headlights on enabled German flyers to locate and to successfully attack these valuable targets. Orientation from the air was also facilitated by the readily recognizable landmark, the broad Dnepr River.

Meanwhile, farther south, the Fourth Air Fleet on 10 October committed 867 aircraft in a concentrated support effort in behalf of the Sixth Army. Bombers, dive-bombers, and ground-attack aircraft attacked Soviet troops, concentrations, and all enemy installations which were detected in the Bolshoy Tokmark-Melitopol, Zaporozhye, and Kremenchug sectors. Certain elements struck the Dnepr bridges at Cherkassy and other enemy targets near Chernigov and Pereyslav. 64 That night, 158 aircraft, mostly bombers and harassing planes, continued the support operations along the Sixth Army front, attacking the Brovari-BakhmachLgov and Preluki-Bakhmach railroads, tactical targets at Pereyslav, the Poltava-Kharkov-Valuyki railroads, and ground targets in the Melitopol

*Editor ${ }^{\prime} s$ Note: See USAF Historical Studies No, 176, pp. 44-45. See also U.S. Department of the Army, Small Unit Actions During the German Campaign in Russia, DA Pam. $\overline{20-269}, \overline{\text { Washington: OCMH, }}$ EUCOM Historical Division, July 1953, pp. 220-228,

fLt. Friedrich Lang. 
area. At least five sizeable trains were destroyed in these attacks and eight others damaged.

Luftwaffe units continued their support operations through the month of October along the ontire southern front, defended by the First and Fourth Panzer Armies and the Sixth and Eighth Armies. Although understrength, the Luftwaffe carried out its support missions with great determination and destroyed a number of bridges, large amounts of enemy materiel, and many Russian troops, 65\%

On the right flank of Army Group South at the bend of the Dnepr, German forces managed to maintain a bridgehead east of the river near Zaporozhye, despite several heavy Soviet attacks. The Luftwaffe supported this defense with over 300 aircraft. Nevertheless, by 14 October enemy pressures had become irresistible and the position had to be abandoned. Just prior to the withdrawal, the railway bridge and river dam, both of which had only recently been repaired and put back into operation, were destroyed by Wehrmacht demolition teams.

The German Sixth Army held its positions between Melitopol and the knee of the Dnepr River at Zaporozhye against heavy Russian attacks until 23 October 1943. On that day Soviet forces breached the defenses at Melitopol and advanced toward the lower reaches of the Dnepr, while some elements of the assault force wheeled about to drive in the direction of Perekop at the neck of the Crimean Peninsula.

The flat plains of the Nogaya Steppe offered no natural lines behind which the Sixth Army might have been able to reestablish itself. Because of this, it was compelled to withdraw its forces rapidly behind the Dnepr River. However, in the course of this retrograde movement, it was able to maintain a strong bridgehead around Nikopol, where its forces halted the Soviet drive and thus protected the rear of the First Panzer Army.

*Within the Fourth Air Fleet area, the I Air Corps (operating in the southern sector) transferred its headquarters on 14 October 1943 from the Crimean Peninsula to Nikolayev. In the central part of the air fleet operational area, the IV Air Corps carried out its tasks from its headquarters at Kirovograd and later at Novo Ukrainka, while in the northern part of the air fleet's area the VIII Air Corps command post was located at Belaya Tserkov. 
Southeast of Kremenchug Soviet forces had crossed the Dnepr on 17 October, and by the 24th other units followed on both sides of Dnepropetrovsk. The Red Army then quickly threw fresh units into the attack, which began to assume grave proportions.

Meanwhile, weather conditions began to deteriorate rapidly all along the southern part of the Eastern Front, with lowering temperatures and some snow. This had an immediate impact upon all military operations in the area. Around Kiev, the heavy concentrations of enemy tanks and artillery, which had been reported in the southern bridgehead area by air and ground reconnaissance, was found to have been a bit of clever enemy deception. After the first snowfall no tracks could be seen on any of the aerial photos indicating entrance into or exit from the bridgehead. This was further confirmed when dive-bombers carried out a small attack on these positions and splintered the timbers from which they had been constructed. 66

By 10 November the Russians had breached the German defenses on a 90-mile front between Dnepropetrovsk and Kremenchug. Forces consisting of 61 infantry divisions, 37 tank brigades, and 14 motorized brigades drove a deep wedge between the First Panzer Army and the Eighth Army, advancing on a broad front far across the Ingulets River north of Krivoy Rog. 67

The Fourth Air Fleet committed all of its available units in continuous combat operations in support of the hard-pressed ground troops, adopting whatever expedients it could to accomplish its mission. A case in point was the airfield situated in the northern outskirts of the village of Bolshaya Kostromka, on the road to Apostolovo, southeast of Krivoy Rog. The road was usually impassable for motor vehicles. For this reason the Fourth Air Fleet immediately trained its personnel to use horses and even oxen, in order to keep the field operational in any circumstances. Quite often crews rode on horseback to their aircraft, dismounting directly from their horses to the planes because the field was in as bad a condition as the road leading to it. In rainy weather the field resembled a muddy lake, with the surface broken here and there by small islands of terra firma. The aircraft could take off only because they were equipped with wide-track tires, such as those used by Ju-87's.

There were certain advantages in the close proximity of German air units to the Dnepr, since the forces could quickly deploy all along the line, depending upon the local situation. Combat missions therefore varied from north to south to east, and changed on very short notice. In the east and southeast Soviet forces brought their weight to bear against 
the Nikopol bridgehead. German air units then struck all Soviet troops and equipment moving in that direction from the Melitopol area, and provided direct support at the focal points of the fighting.

In some of the most crucial areas the map carried numerous German place names such as Heidelberg, Gruental, Gustavfeld, and the like. These were axeas inhabited by Germans, whose ancestors had settled there centuries ago. * Farther to the north the main line of resistance ran along the far side of the Dnepr River, to east of Zaporozhye, where it crossed the Dnepr and extended into the Kremenchug area. Dnepropetrovsk lay in the Soviet reax area.

As had happened so often before, the Russians exerted pressure at several points, and were able to achieve penetrations in more than one place. These were then cleaned out by German counterattacks, usually carried out by panzer divisions. During these actions the Fourth Air Fleet flew numerous close-support missions. Air activity might have been more effective if the Luftwaffe could have used the air base at Krivoy Rog, which was equipped with concrete runways, but, unfortunately for the Wehrmacht, one of the Soviet thrusts reached the airfield and brought it under fire. Red Army units continued to pour in from the area north of this point, in the direction of Pyatikhatki. The situation was restored in the area after a local counterattack, and the front was pushed back a few miles toward the north.

These Soviet forces were receiving their supplies in an uninterrupted flow, for which reason the Luftwaffe attacked the significant Dnepr River bridges. Every third or fourth day the IV Air Corps ordered new attack missions against these structures, usually in the area between Kremenchug and Dnepropetrovsk. 68 Emphasis in these operations changed daily, just as one would expect in a regular fire company, which would be called upon to extinguish one conflagration after another.

On 3 November 1943 the Russians renewed their attack with tremendous force in the Kiev area. This new assault struck the completely

FEditor's Note: In Kiev and in the area to the south of Kiev traces of German influence, such as tiled roofs which dated from the 15 th century, could be seen. The author is probably referring, however, to the descendants of Germans who migrated to this area and to the Volga during the reign of Catherine the Great (1762-1796). 
exhausted troops of the Fourth Panzer Army and the Second Army (Army Group Center). It did not seem to be immediately clear whether the Soviet Command had some long range strategic plan in mind or whether it merely sought to obtain as much room as possible for staging further attacks. Within two days it was clear that Kiev would have to be abandoned. Since it was impossible to shift reinforcements to this area to brace up the reeling German front, Red Army units were able to breach the defenses in places, and on 6 November took the city.

After cracking the Dnepr defenses, Red armies drove rapidly through Fastov and Radomyshl in the direction of Berdichev, Zhitomir, and Korosten. The German Command viewed these developments with foreboding, and saw the threat of an enormously deep and wide penetration between Army Groups South and Center, the results of which might be unpredictable. The left wing of Army Group South appeared to be especially endangered, 69 By 13 November Soviet forces had captured the important rail junction of Fastov and had advanced 96 miles to the west of Kiev into the Zhitomir area, enveloping the LIX Corps at Korosten. At the same time pressures of the heaviest sort were exerted against the German Second Army south of Gomel.

The attack by the main body of Red Army forces at the beginning of these operations between Kiev and Smolensk apparently had produced the results desired by the Soviet Command. It was probably by design that the main attack had been directed at the center of the German line in the Pripyat Marsh area between Zhitomir and Bobruysk, where the lack of roads seriously hampered the movement of Wehrmacht reserves.

For several days in succession Soviet tank divisions and motorized infantry units carried their attack forward on an average of 15 miles a day, and by 15 November 1943 a crisis had developed in the Eastern Theater of Operations on a scale which was then unprecedented in the war. On the following day the advancing Soviet armored forces encountered German panzer divisions (under the command of Generaloberst Hoth and the Fourth Panzer Army) which struck them in the flank and brought their offensive to a halt west of Zhitomir. * All available German air units assisted in stopping this advance.

Counterattacking German ground forces even succeeded by 19 November in driving the Russians back across the Teterev River to a

*Elite units such as the Motorized Division "Grossdeutschland" and the 7th "Ghost" Panzer Division played a role in these actions. 
position east of Zhitomir. Yet, despite the recapture of this area, Korosten remained under siege, Fastov was still in Soviet hands, and the north flank of the Fourth Panzer Army remained open. *

While these operations were still in progress west of Kiev, the Russians again attacked the Sixth Army, the First Panzer Army, and the Eighth Army, but German forces varied their actions from defense to counterattack as the situation required and succeeded time after time in preventing enemy breakthroughs on a large scale.

The VIII Air Corps and its units contributed materially to the successful outcome of the counterattacks, especially that of the 7 th Panzer Division in the recapture of Zhitomir and the airfields in that area. Frequent spells of bad weather and poor visibility because of autumn fogs, as well as the nearly unserviceable condition of the airfields, did not prevent the Luftwaffe from attacking every Soviet target sighted. It was then that the old Hs-123 proved its value. The Henschel 123 was an obsolete biplane with a top speed of about 225 miles per hour, but which was very maneuverable and robust enough to operate even under the worst of weather conditions when other aircraft would be grounded. These planes worked out very well, especially since bad weather had also greatly reduced Soviet air activity.

Apart from the issue of the open north flank of the Fourth Panzer Army, the situation on the ground remained unchanged for some time. In the north, however, the gap in the swampy region around Korosten, which separated the army from Army Group Center, grew gradually wider. The grave danger of a flank threat was fully realized, but no substantial forces were available to stop the slow but steady westward advance of the Soviet forces. The landscape in this area is dismal, the major features being swamps and trackless forests in a region known as the Pokitno swamp. Here the Soviet forces were able to exploit with great adroitness the difficult terrain and to continue their westward progress. The German Command assumed that they would soon outflank the German lines in the Korosten area in the direction of Sarny and that a new Soviet assault would soon take shape in that area.

*The High Command of the Wehrmacht report covering the period 9-15 November 1943 listed Soviet losses at 20,000 dead, 4,800 prisoners, and 603 tanks and 1, 505 guns captured or destroyed. 
The VIII Air Corps did its utmost to insure that the Fourth Panzer Army would have reliable air reconnaissance information. Strategic reconnaissance missions were carried out by the 2 nd Squadron of the 11 th Strategic Reconnaissance Group from Berdichev, and by tactical reconnaissance units operating out of Kalinovka. The airfield at the latter location had been used as a transhipping center during the time when the German front was still far east of the Volga River and later had been developed as a good air base.

German air units were heavily crowded on the few serviceable airfields available. Fortunately for them, the Soviet Eighth Air Army lopposing the German VIII Air Corps) gave little evidence of aggressiveness. Nevertheless, it was a question how long some of these bases could be held. The field at Kalinovka provided good shelter, signal communications, and runways which were useable even during muddy periods, but its facilities came to be used almost exclusively for the bomber units of the VIII Air Corps rather than for general supply and repair services.

One after another, the airfields around Belozerka* and Usin had been abandoned, as the German lines withdrew to the west. Even before the Soviet offensive the retention of the Belozerka field had been in serious doubt because of increasing attacks from large bands of partisans operating from the wooded areas to the east. This greatly facilitated the Red Army's footing in the area. German troops found themselves in exceedingly difficult circumstances in the rough terrain, and the wonder is that they were able to hold out as long as they did.

Farther to the south at Kremenchug, the Eighth Army had also been compelled to withdraw its troops, and after November there could be no further talk of a Dnepr River defense line in that sector.

In the latter half of November, rains created a muddy condition, a gummy morass, which brought all military operations to a halt until freezing weather set in early in December. Mud, slush, fog, and low ceilings restricted air and ground operations so severely that, for all practical purposes, everything had come to a standstill. The Fourth Panzer Army, which had not had time to consolidate its positions properly, was thus able to regroup and make further preparations. More important than this, however, was that the threat of a strategic breakthrough and

*Editor's Note: The author does not make clear whether this was Bolshaya Belozerka or Malaya Belozerka, each close to the other in this sector. 
the splitting of the entire Eastern Front had been forestalled, allowing German combat units all along the front a temporary breathing spell before the arrival of winter. 70

By this time it appeared that the exaggerated hopes of the Western Allies, which they had built up after hearing of the Russian advance at Kiev, had turned to pessimism. For example, on 18 November a report of the British Broadcasting Corporation admitted quite frankly that the hopes which London had placed in the Soviet offensive in the Kiev area had not materialized, and that the only possible result could be a shortening of the German lines, which would increase rather than weaken the Wehrmacht's capability to resist.

Considering this operation against the German center from a tactical point of view, it must be said that the Soviet Command should have proceeded with the aim of effecting an enveloping maneuver, since it has been generally recognized as a time-honored rule that any breakthrough in the center can be halted by moving reserves into the area. In this instance the German counterattack not only stopped the enemy advance, but succeeded in enveloping and destroying a Soviet task force at Zhitomir, and this despite otherwise unfavorable conditions. German air units gave excellent support during these battles, even in poor flying weather. 71

Although the Red Army had suffered a temporary setback far west of Kiev, and although there was momentary comfort in the uneasy stalemate caused by the muddy terrain, Army Group South's position was far from good. Large numbers of Russian troops were regrouping and concentrating for a coming offensive blow, and Wehrmacht leaders realized that far graver events would be in store if the Soviet armies had time to prepare for their next attack.

Hoping to take advantage of the general inertia of the period, the XXXXVIII Panzer Corps* late in November assembled its forces back of the center of the front of Army Group South in preparation for the execution of a spoiling attack against the menacing Soviet concentration. By the beginning of December freezing weather and some snow had arrived, making the ground hard enough for operations by armored and motorized

*The corps comprised the Ist Panzer Division, an outstanding unit, commanded by Generalleutnant Walter Krueger; the 7th ("Ghost") Panzer Division, Rommel's old division, commanded by Generalmajor Hasso von Manteuffel; the 1st SS Panzer Division "Leibstandarte Adolph Hitler, " commanded by SS General Josef "Sepp" Dietrich; and some auxiliary units. 


\section{THIS PAGE DECLASSIFIED IAW E012958}

units. The XXXXVIII Panzer Corps thereupon moved northwestward through Zhitomir to a position behind the left wing of Army Group South. Under cover of darkness these armored forces moved out into the open flank area to the north along the road from Zhitomir to Korosten. All arms and services cooperated in assisting to mask the movements of this corps until the moment for the attack, which was to be the great hour for several outstanding armored force commanders whose names were to find a place in the annals of military history, Generalmajor Hasso von Manteuffel and Colonels Adalbert Schulz and Hyazinth Count Strachwitz von Gross-Zauche und Camminetz. *

On 4 December 1943 the German XIII Corps (defending the left wing of Army Group South just below the exposed flank area), strengthened by the addition of rocket and artillery units, opened the attack toward the north and northeast, an attack which the Russians immediately interpreted as an indication that the Wehrmacht was again going to try to force a decision along that part of the front. The Soviet Command then launched a strong counterattack, sending as many units as possible up to the front area. Here they were met and stopped, despite their numerical superiority, by the surprisingly heavy firepower of the XIII Corps and its supporting units. At this moment, the XXXXVIII Panzer Corps struck the right flank of the attacking Soviet force and drove deeply into its rear area, Maneuvering with great speed over the frozen terrain, the corps soon enveloped and annihilated all Russian units at or near the front lines. The LIX Corps, which had been encircled at Korosten, was also able to execute a successful breakout and establish contact with the XXXXVIII Panzer Corps.

The surprise assault had succeeded, and by 9 December the objectives of the attack had been achieved. Not only was an entire Soviet Army wiped out, but three others suffered such heavy casualties that they were unable to remain on the line. Moreover, the imminent danger of a large-scale enemy offensive had been removed and the German lines were closed from the area east of Korosten southward to a point east of Radomyshl and thence to the road to Fastov, southeast of Radomyshl.

South of the VIII Air Corps area the IV Air Corps was fully occupied in repulsing Soviet attacks along the Dnepr River. In the constantly critical

*Editor ${ }^{\top}$ s Note: All of these officers were subsequently recipients of the Knight's Cross of the Iron Cross with oak leaves, swords, and diamonds. 
battles, particularly in the Krivoy Rog-Nikopol-Kremenchug-Kirovograd areas, units of the IV Air Corps supported the defensive battles and counterattacks of the Eighth and Sixth Armies and the First Panzer Army. Main emphasis was placed upon the First Panzer Army sector. There recurring crises frequently necessitated daily transfers of supporting air units in order to carry out missions in the main battle sectors. Thanks to an excellent communications system, IV Air Corps units were highly successful in their direct support missions, even though their numerical weaknesses prevented them from achieving really decisive results. Luftwaffe-Army cooperation was particularly close and smooth in this sector, a fact which did much to insure the success of air operations. *

Owing to a lack of appropriate forces, IV Air Corps was unable to accomplish any strategic missions, except for those performed by a night railroad interdiction squadron of the 55 th Bomber Wing (equipped with He-111 aircraft), which was dispatched against Soviet supply movements in the rear areas. Although this squadron achieved local successes, it was unable to stop or seriously hamper the flow of Soviet supplies. This was not surprising in view of the fact that the aircraft available for this type of mission were too few in number to effectively attack and destroy all of the numerous targets which were to be found in the enormous area.

The IV Air Corps also flew some attack missions against the bridges at Dnepropetrovsk and Zaporozhye, making solid strikes on the latter bridge, but achieving negative results against the Dnepropetrovsk structure. 72

In December the headquarters staff of the IV Air Corps was withdrawn from the front line area for employment in planning and executing strategic air missions, 73

In the extreme southern part of the Eastern Front the IV Air Corps was obliged to shift its units from one sector to another in support of the Sixth Army, and occasionally to send forces to the Crimean area in support of the Seventeenth Army which was defending there, isolated from other German forces. 74

*Generalleutnant Rudolf Meister assumed command of the IV Air Corps on 13 October 1943, replacing General der Flieger Kurt Pflugbeil, who then became Commander in Chief, First Air Fleet. See figure 32. 


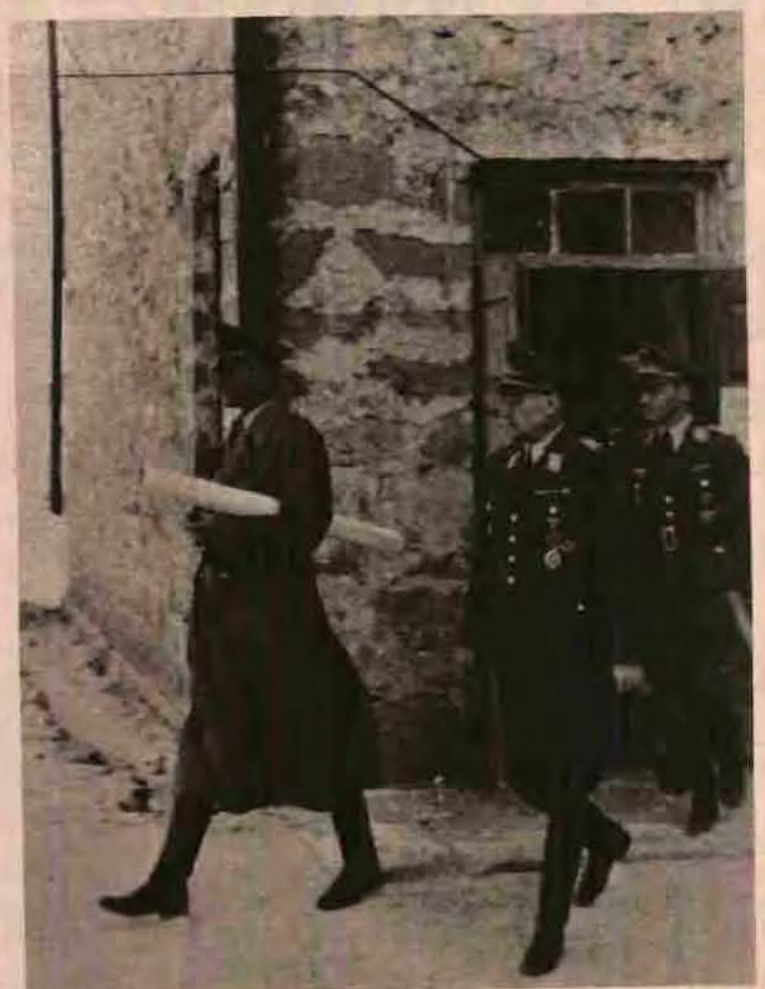

Figure 32

General der Flieger Kurt Pflugbeil leaving IV Air Corps

Command Post, 13 October 1943, after turning over his command to Generalleutnant Rudolf Meister (walking behind him). Emerging from CP is Col. Anselm Brasser (GSC), Chief of Staff, IV Air Corps 
In their almost continuous combat commitment the command and troops of the I and IV Air Corps achieved nearly impossible performances, and provided most effective support for the ground forces in their grim battles. Although both corps were too weak to exercise more than a local effect upon operations, their help was undeniably important to the ground fighting in a particular area, even if it could never result in any strategic change in the situation. *

By mid-December frost and snow had produced the characteristic Russian winter landscape in the Army Group South sector, making the seemingly endless tracts even more barren and desolate. Bitter cold, snow, and driving winds worked a tremendous hardship upon all personnel. On German airfields Luftwaffe personnel worked against the elements, preparing aircraft for take-offs, thawing out and defrosting aircraft and equipment, repairing and maintaining aircraft, and shoveling snow from the runways and hardstands. Under these grueling conditions air support of the ground fighting continued. Being wounded meant freezing to death if help was not immediately at hand, and food was usually frozen solid. Pilots who were forced to make emergency landings in the deep snow usually lost their aircraft and its supplies since salvage operations were so difficult to carry out. Yet, in comparison with the ground forces the Luftwaffe had much to be.thankful for. German flyers usually had habitable quarters, and decent, or passable, rations were always assured.

Just prior to the Christmas season there was a deceptive spell of quiet along the front. Numerous signs indicated that the Russians would soon Iaunch an offensive. The VIII Air Corps and the IV Air Corps were ready for it if it came, but Army Group "A" was in a difficult position. Its Seventeenth Army remained isolated in the Crimea, fearful that it might at any time be brought under heavy amphibious attacks, while the Sixth Army clung to its line along the lower reaches of the Dnepr River. Adjacent to it on the north was Army Group South's First Panzer Army, and north of that the Eighth Army and Fourth Panzer Army in positions extending from Nikopol to Zaporozhye to the Krivoy Rog area to Kremenchug, along the western bank of the Dnepr River to the Kanev area, and thence in a wide arc to the Zhitomir area farther west. 75

*Editor's Note: During this period of weakness and decline in the Wehrmacht the Soviet Union had greatly increased its war production. ( $\mathrm{T}-34$ tank chassis were being made at a rate of 2,000 a month.) This, added to the Lend-Lease assistance, gave the Russians an overpowering advantage. Sele Kenneth $\mathrm{R}$. Whiting, The Development of the Soviet Armed Fortes, 1917-1966, AU-10, Maxwell AFB, Alabama: Documentary Research Division, ASI, 1966, p. 52. 
In the south the German line presented an almost impossible appearance. While it was bent far back to the west in the area east of Zhitomir, the Eighth Army was still in position along the Dnepr River in the Cherkassy area. South of this the line again bent westward to Kirovograd, where panzer divisions carried on a see-saw battle, endeavoring to halt the Russians, while the Sixth Army held its lines. Shortly before Christmas the Kherson bridgehead had to be evacuated because of drift ice in the Dnepr River, and because there was a serious threat that large Soviet forces would cross the river as soon as it had frozen over. 76

All along the line in the sectors of Army Group South and Army Group "A" the armies were fully engaged in a flexible mobile defense, being constantly supported by the I and VIII Air Corps of the Fourth Air Fleet. The battle was still in full swing in all areas as the Soviet Command continued to commit new masses of troops. The almost continuous battle was beginning to tell on the German forces, which by this time were nearly exhausted.

The end of 1943 was near, the year in which the tide of fate in the East had turned against Germany. A new giant offensive was to be expected shortly in which the Russians would commit even greater masses of men and materiel than ever before, especially against the left wing of Army Group South in the area west of Kiev, at the most seriously threatened sector. The monstrous storm that was brewing broke on 24 December. 77 


\author{
Chapter 5 \\ AIR AND FLAK FORCES IN THE BATTLE FOR THE CRIMEA
}

On the night of 9 October 1943 the last elements of the Seventeenth Army (General dex Pioniere* Erwin Jaenicke) withdrew from the Kuban bridgehead area and crossed over the Straits at Kerch to the Crimean Peninsula. The 9th Flak Division (Generalleutnant Wolfgang Pickert) also withdrew with its 13 flak and 2 searchlight battalionst along with the Seventeenth Army forces. The Division's mission was to provide air defense over the field of battle, to protect all airfields, naval bases, and the ports of Feodosiya, Sevastopol, Yevpatoriya, Chernomorskoye, temporarily also of Genichesk at the western end of the Sea of Azov, and to provide defenses for the rail junction of Dzhankoy. $1 \mathrm{ft}$

On 14 October the Fourth Air Fleet transferred the staff of the I Air Corps (Generalleutnant Karl Angerstein) from the Crimean Peninsula to Nikolayev. This corps had supported the Seventeenth Army most effectively during the defense of the Kuban bridgehead and was to continue to do so when necessary, although its new primary mission was to support the Sixth Army, which, after mid-October, came under heavy assaults by the Red Army. **

At this time the Seventeenth Army controlled five divisions, two assault gun brigades, and seven Rumanian divisions, two of which were partially motorized cavalry divisions. The only flying units in the area were those assigned to Air Command Crimea (Col. GSC Joachim Albrecht Bauer), whose command post was situated at Seventeenth Army Headquarters at Simferopol. These air forces consisted of a dive-bomber group, a few tactical reconnaissance aircraft, and the naval air units which

\$Editor's Note: General der Pioniere, like General der Infanterie, General der Flieger, etc., is a German Wehrmacht rank, corresponding roughly to that of a U.S. Lieutenant General. Pioniere (Pioneers) refers to the basic arm of service of the above-mentioned officer, in this case the Combat Engineers.

fThese were comprised of 28 heavy and 27 light flak batteries and 8 searchlight batteries, with attached units.

t+See Maps Nos. 12 and 13.

**See p. 138. 
were stationed in the Crimean Peninsula, 2* General Jaenicke had joint command authority over all units of the Army, Navy, and Luftwaffe in the Crimea, which therefore included tactical control of Air Command Crimea.

The dive-bomber group represented the only highly mobile reserve force available in the Crimea which could be immediately employed against all land and seaborne targets. Among its successful achievements was the destruction of three modern type Soviet destroyers, which on 7 October 1943 had shelled the coast of Yalta. The dive-bomber group was then just about to take off on a mission against a land objective when it received word from air reconnaissance that destroyers were approaching the coast. Changing bomb loads at once, the dive-bombers quickly got into the air and established contact with the reporting reconnaissance aircraft, which led them to the site. The group carried out repeated attacks upon the three enemy warships, sinking them all. 3

As early as mid-October the Seventeenth Army, in anticipation of later developments, had prepared what was called Plan MICHAEL, a plan for the systematic evacuation of the Crimean Peninsula. At the time, the situation was becoming increasingly critical along the extreme southern wing of the Eastern Front, especially in the Sixth Army sector, and it appeared more and more likely that the Sixth Army would soon have to retire behind the lower reaches of the Dnepr River. 4 Plan MICHAEL called for a great amount of self-sacrifice and outstanding march performances on the part of all of the involved troop units, and it was understood that much of the heavy equipment might have to be abandoned in the process.

Under the provisions of this plan, Kerch was to be evacuated and all units withdrawn to the Parpach positiont during the night of 29 October. On the following night the southern coast of the Crimea, with the exception of Sevastopol, was to be evacuated as far as the heights of the Yayla Mountains, and by 2 November the main line of resistance in the Crimea was to run approximately from Simferopol to Karassubasar to the railroad station at Gramatikovo. The final designated line (Yevpatoriya-OktyabrskoyeYayla Mountain ridge) was to be reached by 4 November, from which time

*When the staff of the I Air Corps was transferred to Nikolayev (Army Group "A" sector), Air Command Black Sea (responsible for reconnaissance and air defense in the Black Sea area in cooperation with Admiral Black Sea) was redesignated Air Command Crimea.

tA fortified line built in 1941 by the Russians across the neck of land from Kamenskoye on the Sea of Azov to the Black Sea northeast of Feodosiya. This line of bunkers changed hands several times in the course of the war. 
the further withdrawal was to be accomplished as circumstances permitted. A single-track railroad from Kerch was available for the withdrawal of the 50 th Infantry Division. 5

Because of the gravity of the overall situation General Jaenicke, commanding the Seventeenth Army, acting upon his own initiative, ordered preparations to begin for the implementation of the first phase of Plan MICHAEL, 6 According to Generalleutnant Angerstein, this order was issued contrary to the explicit directions of Army Group "A. " Under the evacuation plan, Air Command Crimea was placed under the command of Generalleutnant Pickert, Commanding General of the 9th Flak Division, who, in turn, was subordinate to General Jaenicke. Both of these officers had been caught in the Stalingrad pocket and had been flown out at the "eleventh hour," so that they were naturally sensitive to envelopments. *

All units in the Crimea worked with feverish haste, and the concrete runways at Baggerovo were already demolished when the I Air Corps heard what was happening and took appropriate steps to prevent the destruction of the ground installations which were required for the conduct of operations. At about 2100 hours on this same day (28 October 1943) the highest command interceded and ordered the immediate discontinuance of the evacuation plan and the return of all involved units to their former stations. Some forces moving in the northern Crimea, however, had to continue on their way in order to reinforce points threatened by enemy forces. Because the Seventeenth Army had implemented Plan MICHAEL (I) contrary to orders, and because of the resultant overlapping chain of command, confusion reigned in the Luftwaffe ground organization for two or three days. 7

Although General Jaenicke had flown personally to the Fuehrer's Headquarters, he had been unable to secure any change in the order forbidding the execution of Plan MICHAEL. In fact, he had been ordered

क्Wditor's Note: Jaenicke was, in some respects, a controversial character. Paulus in December of 1942 called him an ideal army commander, "absolutely firm in crises." On 31 January 1944 Field Marshal von Kleist noted in his efficiency report, "Personally very active and impulsive, so that he requires a steady and sober chief of staff. . . On 28 October 1943 he ordered the evacuation of the Crimea against the directives of the Fuehrer and the Army Group. Now he presents the matter as if it had not been an act of disobedience, but simply a pressure device to secure additional forces." See personnel data on file, Karlsruhe Document Collection. 
to hold the Crimea at all costs. This area was of military importance chiefly because it served as a massive aircraft carrier. There were a number of good airfields there which had been recently equipped for full air operations and which provided favorable bases for Luftwaffe attacks upon industrial targets in southern Russia, the Caucasus oil region, the highly important Anglo-American supply routes from Iran and the Caspian Sea, and against the remarkably passive Soviet Black Sea Fleet.

The significance of the Crimean Peninsula as a base of operations against the Trans-Iran supply route is strikingly revealed in the October 1943 issue of the American periodical Impact:

. . . in many ways the 9,000 -mile air route to the Persian Gulf represents the most spectacular development. Touching four continents, it hops from Miami to Natal to Ascension to Accra to Cairo to the mud flats of Abadan. The route goes on to India and China. But at Abadan supplies are picked up by the Russians and transported by plane and truck through Baku to South Russia. 8

Early in 1942 work commenced under the supervision of the U.S. Army to develop Abadan, Iran into an important air base for the delivery of warplanes to Russia. This was part of the War Department's plan for creating a supply route to the Soviet Union through the Persian corridor. Preparing this system entailed the construction of assembly plants, roads and bridges, the improvement and expansion of port facilities, and the transfer of railway rolling stock. In order to implement this plan, 1,398 American officers and 26,539 enlisted men were transferred into the area.?

By 1 September 1943 the United States had flown 1, 702 aircraft ( 1,000 of them light and medium bombers) via Africa to Abadan, while 602 planes had arrived by sea. Fighter aircraft were transported to the Persian Gulf by ship, then uncrated and assembled at the Allied installation in Abadan, where Russian pilots picked them up. The Air Transport Command took charge of all airborne traffic, and, while many aircraft were delivered to the Soviet Union over the Alaska-Siberia route, this avenue was soon outstripped by the Persian Gulf shipments. The Russians usually determined the desired reception area on the basis of the situation on the fighting front. Those victories in the southern areas during 1943 
appeared to be related to the very substantial delivery of American aircraft through the Persian corridor at Abadan, $10 \%$

Air bases in a Soviet-controlled Cximea would have presented an exceedingly grave threat, particularly to the Rumanian oil fields which were of such decisive importance to the German military effort. Furthermore, the use of the Crimean seaports, especially Sevastopol, would have given the Soviet Black Sea. Fleet good additional naval bases and would thereby have considerably improved its operational possibilities. But there were other reasons why the Crimea was important. The uncertain neutrality of Turkey and the equally uncertain behavior of Germany's ally, Rumania, made the possession of the Crimea of primary political significance.

The German flag flying over the ports of Yevpatoriya, Sevastopol, Feodosiya, and Kerch, the drone of German aircraft engines on the airfields at Kerch, Sarabuz and Karankut (the latter two north of Simferopol), and on the large airfield at Khersones near Sevastopol could not fail to impress Turkey, which would thus have assurance that the Straits of the Bosporus were doubly secured. Turkey was therefore prepared to allow the passage of merchant ships belonging to countries bordering upon the Black Sea in accordance with the Montreux Straits Agreement, f providing that they were connected with the Axis powers. 11

In the conflicts of opinion concerning the question of evacuating the Crimea, Hitler insisted upon unconditional retention of the peninsula, just as he had done in the Kuban situation. The entreaties of Generaloberst Zeitzler to withdraw Wehrmacht forces from the Crimea were therefore utterly useless. 12 During a conference on the subject held early in November, the Fuehrer strongly reaffirmed his position to von Manstein,

*Editor's Note: For an interesting treatise on the establishment of the Persian corridor Lend-Lease route see Richard C. Lukas, "The Middle East-Corridor to Russia: Lend-Lease Aircraft to the Russians, 1941-1942," The Airpower Historian, Vol. XII, No. 3, Montgomery, Alabama: The Air Force Historical Foundation, July 1965 . See also Theodore E. Whiting, Carrel I, Tod, and Anne P. Craft, The United States Army in World War II: Statistics, Lend-Lease, Washington: Department of the Army, OCMH, 15 December 1952 . See also figures 33,34 , and 35 .

\$Editor's Note: An agreement enacted $20 \mathrm{July} 1936$ between Turkey and the signatories of the Lausanne Treaty (Italy abstaining) which returned control of the Straits and the right to refortify them to Turkey. Turkey's requests were met because of its support of the League of Nations' position during the Ethiopian crisis. 


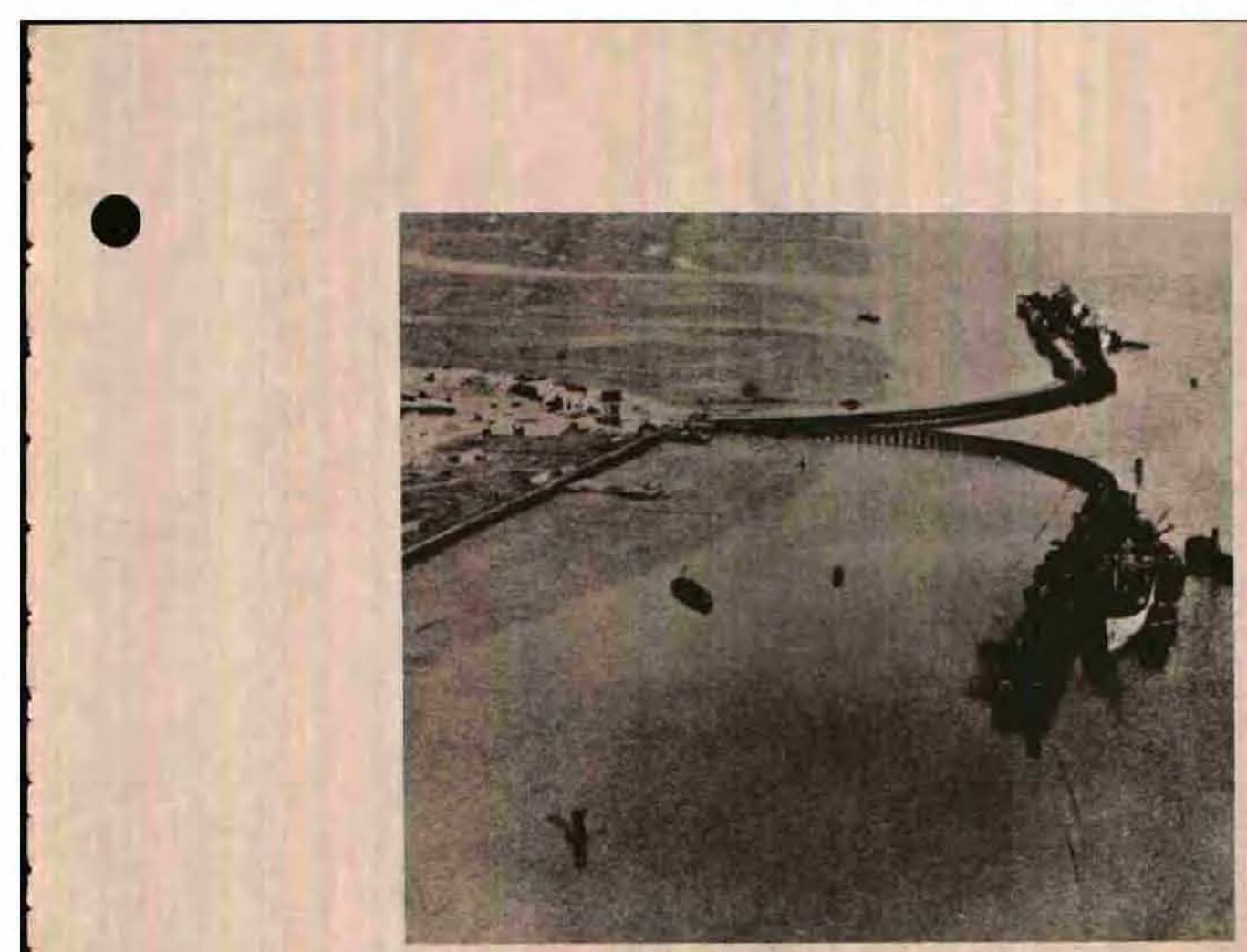

Figure 33

Anglo-American supplies went overland to U.S.S.R. from Bandar Shahpur on the Persian Gulf

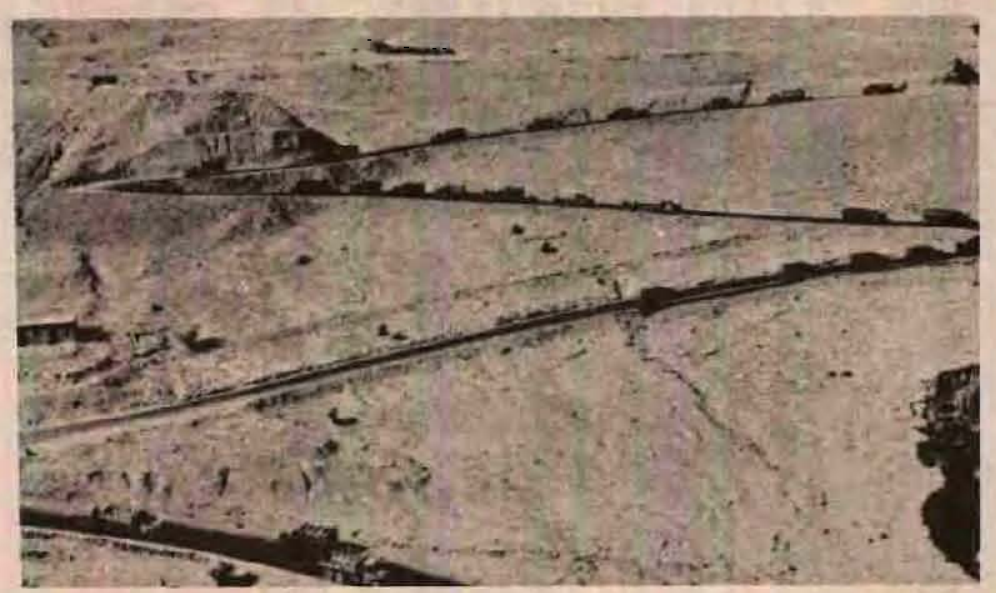

Figure 34

Trucks moving along dusty route from Persian Gulf to Russia 


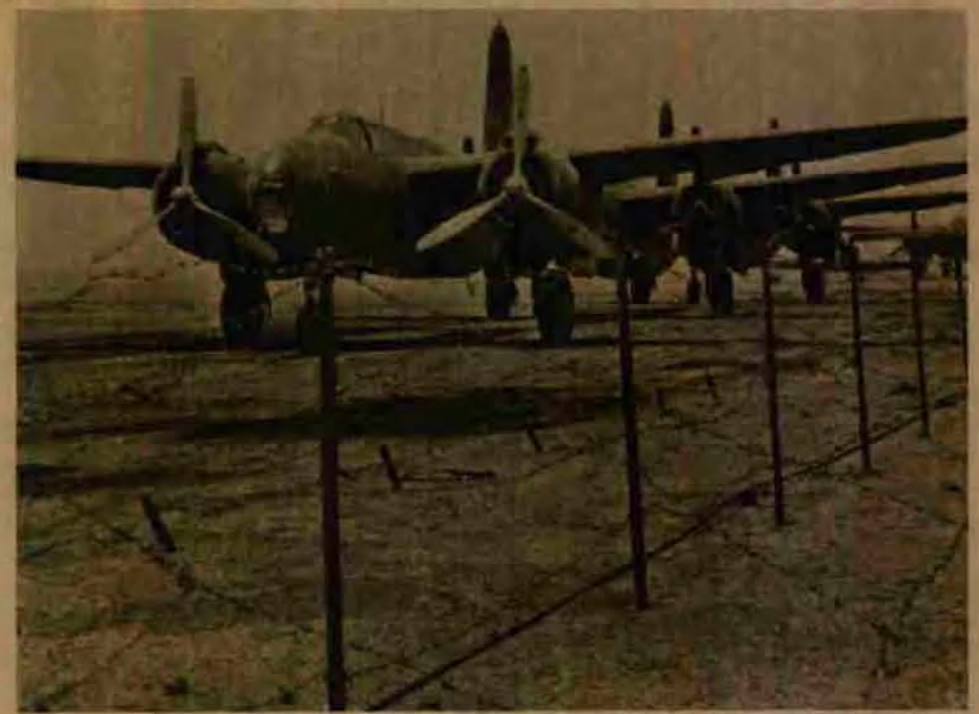

Figure 35

American A-20 aircraft lined up on the Abadan airfield for delivery to the Soviet Union 
pointing out that the loss of the Crimea would naturally lead to the immediate occupation of the area by Soviet forces and, inevitably, in a change of attitude on the part of Turkey, Bulgaria, and Rumania. 13\%

On 28 October the Soviet Fourth Ukrainian Army Group broke through the Sixth Army front at Melitopol and drove into the Nogayan plains. The Sixth Army, whose southern wing had held the line from the bend of the Dnepr River to the Sea of Azov, was then in danger of being enveloped, and, under crushing enemy pressure, withdrew its right (southern) wing toward the lower reaches of the Dnepr and the crossing point of Berislav. This evacuation included the forces stationed around Genichesk at the western tip of the Sea of Azov. During the withdrawal movement the IV and XXIX Corps of the Sixth Army formed a broad bridgehead south of the bend of the Dnepr River. After this army had retired behind the Dnepr, those areas of its former sector which were not immediately overrun by enemy forces were occupied by the right (southern) wing of Army Group South (Manstein), leaving Army Group "A" with only one serious worry, the plight of the Seventeenth Army in the Crimea. There was, of course, the danger that Red units might drive toward the north to cut off the First Panzer Army near Nikopol. $f$

Sizeable elements of the Soviet breakthrough forces wheeled across the Nogayan plains southward toward Perekop, the northern approach to the Crimean Peninsula, where they threatened to deprive the Seventeentin Army of its last land communication with the rest of the German front. 14 Because of the serious situation, the Commanding General of the I Air Corps (Angerstein) transferred his headquarters from Nikolayev back to Simferopol. ft $\mathrm{He}$ then established an excellent wireless teletype communication network with Army Group "A," the Fourth Air Fleet, and the 2nd Squadron (so-called Supply Squadron) of the I Air Corps. 15 From his new headquarters Angerstein directed the operations of all Luftwaffe units stationed in the Crimea and in the Nikolayev and Kherson areas.

Units of the 9th Flak Division stationed in Genichesk were also withdrawn on 28 October to reinforce the weak Rumanian holding forces on the

*The Rumanians entered the war with great zeal, almost with a crusading spirit, but soon became disenchanted when it became clear how great their sacrifices would be in a war of such scope. Moreover, once they regained northern Bucovina and Bessarabia (wrested from them by the Soviet Union in the summer of 1940), they had little interest in the war.

tSee Maps Nos. 12 and 13.

ftSee p. 138. 
Chongar Peninsula to the south. Generally speaking, the situation in the northern Crimea was such that the flak batteries were the only available artillery for the weak security forces in that sector. However, the rapid movement of these batteries was hampered by a shortage of transportation, forcing each battery commander to improvise as best he could. This problem notwithstanding, two heavy $(8.8-\mathrm{cm}$.) batteries succeeded in reaching the northern perimeter of the Tatars ${ }^{1}$ wall* at Perekop early on the morning of 30 October, and were able to prepare for action at once against the expected assaults of Soviet armored spearheads. These defenses were also strengthened by the improvised armored flak train which moved through Dzhankoy in the direction of Armyansk. 16

The arrival of these forces was none too soon, for on that day Russian units reached the Perekop isthmus and severed the Seventeenth Army's last land connection with the remainder of the German ground forces in the East, leaving only sea and air transportation for the movement of vital replacements and supplies. $17 f$ It was only by the stoutest defensive fighting, supported by the dive-bomber group and the 9 th Flak Division, that the Seventeenth Army was able to prevent an immediate Soviet follow-up and breakthrough in the Perekop narrows.

The first Russian tanks (obviously units which had outrun the general enemy advance) actually appeared before Perekop on the 30 th, and were immediately brought under effective artillery fire by German batteries. For the next two days $8.8-\mathrm{cm}$. flak batteries held off these armored forces, destroying large numbers of tanks in the open, flat terrain, where they were visible at great distances and offered such excellent targets for the fast and precision fire of German crews. The armored flak train also achieved particularly good results in its bold forays on the rail line

"Editor's Note: A centuries old, 50-foot-deep ditch with parapet across the narrows just south of Perekop, running from the Bay of Perekop to the Sivash Sea, which was an obstacle of some consequence in the German conquest of the Crimea in the autumn of 1941. See Generalleutnant a. D. Hermann Plocher, The German Air Force versus Russia, 1941, Maxwell AFB, Alabama: USAF Historical Division, ASI, 1964, $\frac{1}{\text { p. } 211}$, and footnote, P. 203.

fDuring the initial stages of isolation one squadron of "Gigant" (Me-323) aircraft, called by the troops adhesive-tape bombers, was available as a supplement to sea transports for the rapid movement of vital supplies and equipment. 
northwest of the Tatars' wall. In these few critical days the flak train destroyed 24 Soviet tanks. *

On 2 November some small Soviet units crossed the Sivash Sea from the north and reached the Dzhankoy-Perekop rail line west of Voinka. By the following day a large enemy force began to assault the Tatars' wall, defended by elements of the XXXXIX Mountain Corps (General der Gebirgstruppe Rudolph Konrad) of the Seventeenth Army, a badly understrength unit which was weary from months of heavy fighting. It could not expect much assistance from the forces in this area, which included a German battalion, a Ukrainian battalion, a Rumanian battalion, and one battalion of the supply column of the 4th Mountain Division which got left behind in the withdrawal of the Sixth Army. It was also unlikely that help would be forthcoming from the 50th Infantry Division (then in march) for at least two days.

Soviet armor, accompanied with armored infantry forces, broke through the Tatars' wall on 3 November and drove southward as far as Armyansk, where they were stopped by the determined defensive forces, prominent among which was an outstanding battery of the 9th Flak Division.t The dive-bomber group stationed at Karankut and bombers and groundattack aircraft from Nikolayev and Kherson then participated in the severe actions which followed. The bombers attacked the rear Soviet airfields at Kalanchak and Chaplinka, while the ground-attack planes, escorted by fighters, attacked enemy forces advancing in the northern approaches to the Crimea.

The dive-bomber group was committed in the breakthrough area and performed extremely well under the conditions. On 5 and 6 November, when the fighting around Armyansk was especially heavy, visibility was about 1,000 yards and the cloud ceiling was below 800 feet. The divebombers were not properly equipped for instrument navigation, which, of course, ruled out any hopes for accurate air strikes. However, this excellent group still carried out several attacks each day against Soviet forces in the area in an effort to relieve the pressures on the German infantrymen. 18

*An improvised train, mounting two $8.8-\mathrm{cm}$. and several $20-\mathrm{mm}$. flak guns on each rail car, the sides of each car being protected by double concrete plates. This train rendered outstanding service and its young commander received the Knight's Cross for his ingenious operations. See figures 36 and 37 . fOf the 86th Light Flak Bn. 


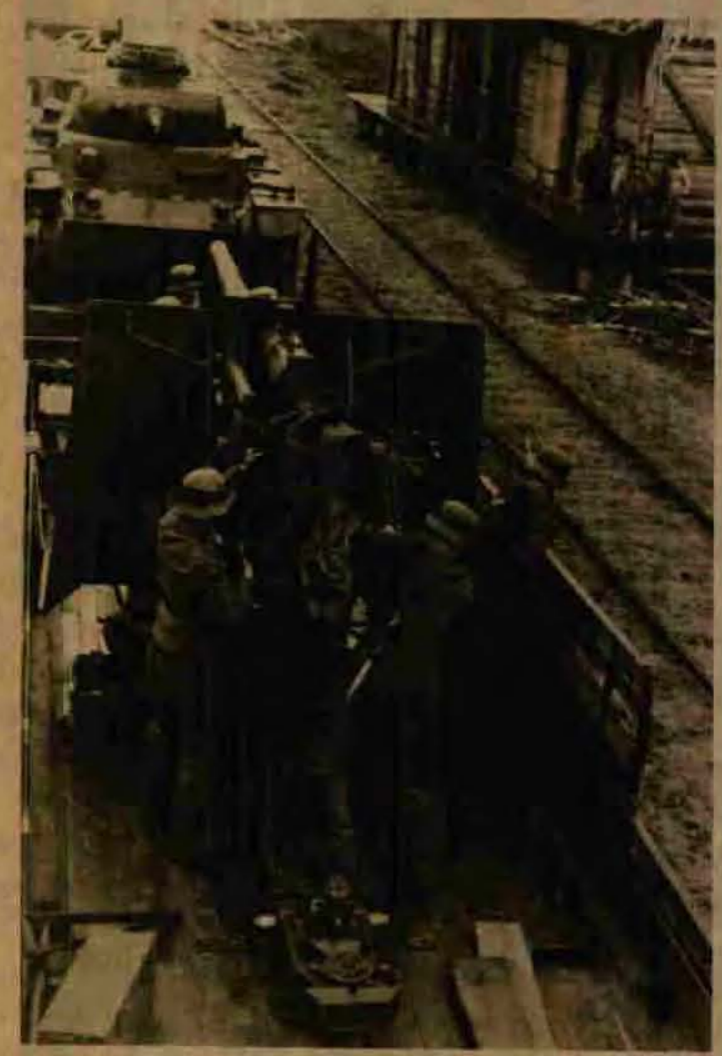

Figure 36

Flak crew (8.8-cm.) preparing for action aboard an armored flak train 


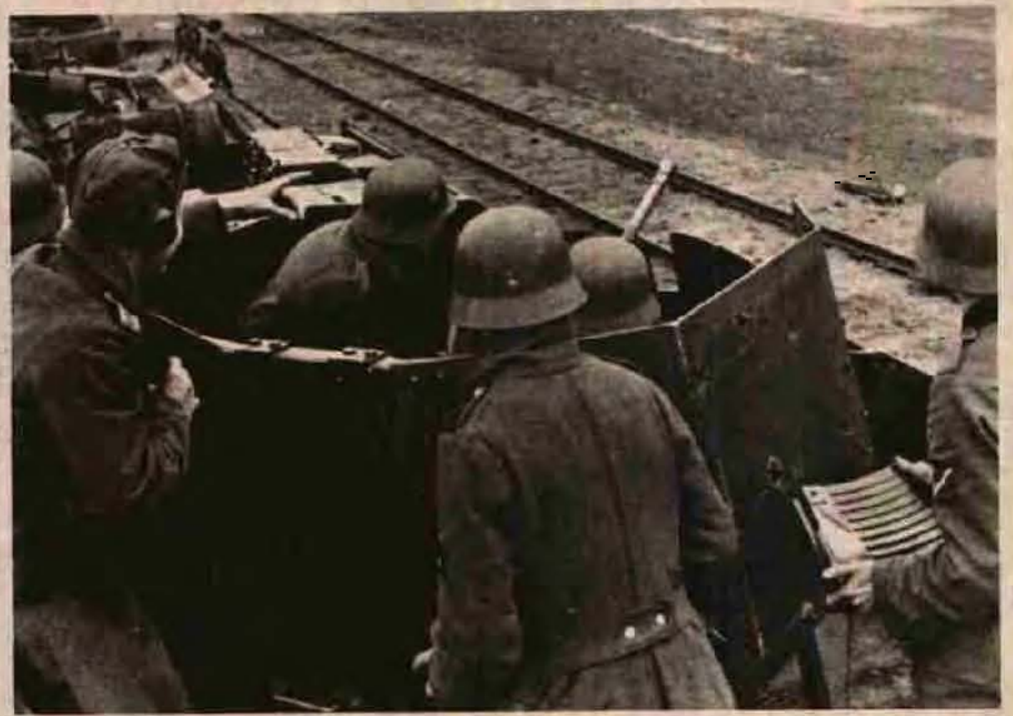

Figure 37

Flak gun (2-cm.) going into action aboard an armored train 
At the end of October, almost simultaneous with the opening of battle around Perekop, a new crisis developed in the eastern part of the Crimea. Soviet forces had landed along the rugged coast at the northern outlet of the Straits of Kerch and were fighting desperately to expand their initially small beachheads. However, before countermeasures could be taken to eliminate these footholds, or before the infiltrations--at which the Russians were so adept--could be halted, a new surprise materialized along the weakly defended 21 -mile front facing the Straits.

Early on 1 November 1943 some small Soviet units succeeded in securing a footing along the coast about 18 miles south of Kerch. Rumanian holding forces along the line in this area destroyed one Russian landing craft by antitank fire, and it appeared that the entire operation was just another small-scale attack similar to those of the preceding days to the north of Kerch. Actually it was merely a diversionary movernent to cover a large-scale landing which took place after dark near the village of Eltigen, eight miles south of Kerch. At 0230 hours Russian long-range artillexy suddenly opened a heavy barrage upon this area, which lay only about nine miles across the Straits. Simultaneously, a force of 20 to 30 harassing aircraft commenced bombing Eltigen and the area farther to the south. The 89 th Light Flak Battalion, which was deployed in that sector, could not take defensive action because it had no searchlights.

Soon after the Soviet guns opened fire, a large number of enemy landing craft appeared before Eltigen, having approached under cover of heavy fog. Red Army forces landed, drove out the Rumanian holding group, and in a short time established a beachhead 3,000 yards long and from 400 to 800 yards in depth. The 89 th Light Flak Battalion on the western outskirts of Eltigen sank 10 landing craft and halted a further expansion of the beachhead, but was unable to prevent the landing because the Rumanian holding force had withdrawn. During the forenoon German reserves were rushed into the area to prevent any additional enemy advance. 19

The Russians had been able to make preparations for this amphibious operation without German notice because of the poor visibility and because the few remaining tactical reconnaissance aircraft still in the Crimea had no fighter escorts and were thus unable to carry ont adequate reconnaissance missions, V Corps Headquarters, lacking sufficient information on the local situation, rejected the I Air Corps' offer to immediately order out the dive-bomber group stationed at Karankut* on

*With its concrete runways, this airfield remained operational despite autumn rains which turned most of the earth into a morass. 
an attack mission with small fragmentation bombs. Had this force been dispatched it would undoubtedly have been highly effective. 20

Pursuant to Seventeenth Army instructions, the I Air Corps ordered all of its available forces from the Nikolayev and Kherson airfields to attack the Soviet vessels crossing the Straits. During these repeated attacks, the Russians suffered heavy losses.

The situation of the Seventeenth Army was truly critical in the early part of November 1943, with enemy footholds north and south of Kerch, without local reserves to throw these forces back into the sea. Inroads in the north were serious with many local breakthroughs along the Sivash Sea area; always there was the threat of a major breakthrough. The problem of defense was aggravated by the poor communication routes in the Crimea. The front along the Kerch area was about 129 miles from the front along the Sivash Sea sector, and the one single-track railroad did not permit rapid transfers of units along interior lines. As if these problems were not enough, long nights and periods of heavy fog caused additional difficulties.

While some German forces were tied down by the new Soviet beachhead at Eltigen, the Russians moved in sizeable reinforcements northeast of Kerch. On 11 November enemy forces attacked from this beachhead, using for the first time armored support, which enabled them to rapidly expand their beachhead to a width of 8,000 and a depth of 5,000 yards. A few of the tanks were destroyed by weapons fire, three of them by flak batteries, but they had achieved their purpose and given the Soviet Command a staging area for a large-scale attack and for the assembly of artillery. Because of this, the German V Corps (General der Infanterie Karl Almendinger), which was responsible for the defense of the sector, had to commit strong forces to hold the line.

The Seventeenth Army's situation was obviously difficult, especially in the Kerch area and on the northern front of the Crimea along the Sivash-Tatars' wall sector, areas which had fallen under Soviet control and from which the Russians could launch a decisive attack for the recapture of the peninsula whenever they desired. In these circumstances it was of primary importance for the Seventeenth Army to conceal its weaknesses, to eliminate Soviet positions through local counterattacks, and to husband its strength by attacking only when and where the chances for success were propitious. The first of these local attacks was in the sector along the 
Sivash Sea north of Voinka, Here Rumanian and German units* on 27 November gradually compelled the Red Army forces to withdraw from this foothold toward the north. However, in spite of weeks of hard fighting, the Axis units were unable to throw the Russians back across the Sivash Sea, 21 The Russians held tenaciously to their bridgehead on the Chigary Peninsula, 12 miles north of Voinka, where they succeeded after weeks of night labor in building a causeway for vehicular traffic across the Sivash Sea, which at that point was about 2,000 yards wide. This work was accomplished in spite of repeated aerial bombardments and harassing artillery fire, and must be considered as a remarkable achievement. Unfortunately for German forces in the area, the long nights, frequent spells of heavy fog, and general observation difficulties prevented friendly forces from taking more effective action. 22

Fighting was less severe during the latter half of November and the first part of December, by which time the Seventeenth Army was able to proceed with plans to regain some of its lost territory by counterattack. There were several choices open: to fight in the northern Crimea with the intention of winning back the Tatars' wall, to seize the Chigary Peninsula, to force back the enemy bridgeheads north of Kerch, or to destroy the enemy bridgehead at Eltigen. The latter course was deemed the most favorable for the Seventeenth Army's weak forces.

After careful preparation, and with powerful support from the I Air Corps and the 9th Flak Division, German and Rumanian units launched on 14 December 1943 a counterattack to eliminate the Soviet bridgehead at Eltigen. The Soviet Command had made desperate efforts to maintain and even enlarge this position, and had resorted to the use of air-drops for the logistical support of forces at that point. Mast of the aircraft involved in these operations, however, were shot down by German flak units.

The counterattack was successful and resulted in the recapture of the Eltigen area with a loss to the Russians of 80 boats, 15 aircraft, a large number of weapons, and many casualties. On the night of the 14th, however, a force of several hundred enemy troops broke out through the Rumanian positions without being detected. This force then proceeded northward toward Kerch, overrunning several small German units enroute, and arrived at the heights of Mitridat west and southwest of the city of Kerch. This enemy group was finally eliminated by Wehrmacht forces,

Flements of the German 336th Infantry Division and Rumanian units, supported by the 86th Light Flak Battalion. On 27 November alone, 100 Soviet dead were counted in the $3 \mathrm{rd}$ battery area, and on 2 December another 60 dead, according to after-action reports of the 86th Light Flak Battalion. 
but not before it had caused a considerable amount of trouble for Seventeenth Army units.

On 16 December a futile attempt was made by Soviet forces, using a few S-boats* and five ground-attack IL-2 aircraft, to assault the German positions at Eltigen. The exact purpose of this attack was uncertain, since the forces employed were by no means commensurate to the requirements of the situation. German flak forces destroyed one boat, drove off the others, and shot down one "Stormovik."

It seemed that the Russians were temporarily satisfied with their gains in the north on the Perekop isthmus and farther to the east along the shores of the Sivash Sea. The Seventeenth Army made a careful study to determine whether further counterattacks such as that at Eltigen could be made in the northern Crimea, but concluded that any such efforts would only result in a weakening of the army's defensive power and in the Chigary Peninsula in the possible loss of considerable heavy equipment, including self-propelled guns.

Fears that the Sivash Sea, despite the salt content of its water, might freeze over and permit mass enemy crossings did not materialize because of the mild weather. Therefore the German defenses were temporarily adequate along this front and the combat activities along the Tatars ${ }^{\prime}$ wall and Sivash Sea areas remained relatively minor in character. During this time the Wehrmacht improved its positions and laid plans for the eventual evacuation of the peninsula.

One remarkable feature during the winter of 1943-1944 was the large number of propaganda leaflets which were dropped by Soviet aircraft. In these efforts the Soviet Command endeavored to direct its propaganda attack at individual German divisions, giving the names of unit commanders and any derogatory information about them. These leaflets also specified by name persons whom the Red Army had allegedly captured unharmed while on patrol missions. From the information given it was obvious that the paybooks of these men had come into Soviet possession, $f$ The 9 th Flak Division was favored with one of these direct

*Editor's Note: Similar to the U.S. PT motor-torpedo boat. The term "S-boat" is a German appellation from Schnellboot (fast boat). fEditor's Note: All members of the German military services were required to carry with them a Soldbuch (paybook), which also served as a personal identification record. This could be demanded at any time by commissioned and non-commissioned officers, police officials, or other proper authorities. Early in the war the designation of the unit to which the bearer belonged was shown in the book, but this practice was later abandoned for security reasons. 
addresses, which contained a crude mixture of threats and blandishments. 23

Frequently repeated enemy air attacks against various parts of the main line of resistance and airfields on the Crimean Peninsula resulted in heavy Russian losses due to German fighter and flak defenses, Russian air units made repeated attacks upon the small supply and naval base at Ak-Mechet in the northwestern corner of the peninsula, and German flak batteries regularly shot down a number of IL-2 aircraft in this area.

The port of Ak-Mechet was also the scene of an interesting incident which occurred during this period. A Russian motor-torpedo boat entered the harbor in broad daylight and was recognized as a hostile craft only after it was already within the port. Without attacking, the boat immediately turned about and attempted to escape. At this very late juncture German light flak guns opened fire and sank the vessel, Members of the crew of this Soviet boat who were rescued by the German Navy stated that they had lost contact with their parent organization and all sense of orientation, and assumed (incorrectly as it turned out) that they were on the opposite shore, which was already occupied by their own forces. Their navigation was off by 1800.24

During this time, in spite of Hitler's orders to bold fast in the Crimea, the Seventeenth Army continued its plans for the evacuation of the peninsula, either as a tactical withdrawal or as a last moment retirement in the face of enemy pressure. Plans provided for a rapid retrograde movement to the fortified Sevastopol area, from whence all forces were to be evacuated by sea and air. Seventeenth Army then ordered the preparation of phase lines with antitank defenses to delay the enemy follow-up or a possible enveloping pursuit by Red Army tank and motorized forces in the broad, open terrain of the Crimea.

In the words of Generalleutnant Pickert:

The fundamental idea was, in a foreseeable time, to prepare the obviously coming evacuation of the Crimea by the construction of positions which would ease and make possible through phase lines the retreat to Sevastopol and the related evacuation. The only possibility for an evacuation seemed to be through this fortified and port area. 25

Since the evacuations of the Caucasus and Kuban areas, the Seventeenth Army had come to appreciate the capabilities and, therefore, 
the special significance of air transportation. Great importance was thus attached to the expansion of existing airfields and to the development of additional airfields within the fortified area of Sevastopol. The use of the latter for operational purposes was expressly prohibited in order not to reveal the presence of these fields to the enemy prior to the beginning of the evacuation movement.

Work was commenced in June of 1943 on the repair and expansion of the Khersones airfield, which was used by the Russians in their evacuation of the Crimea during Manstein's operations in 1942. The tremendous blows rained upon the field at that time by von Richthofen's VIII Air Corps had completely demolished the base and rendered it unfit for operations. By the end of September, however, the runways had been completely reconstructed.

\section{Inftwaffe Activity in the Crimea in the Winter of 1943-1944}

Generalmajor Paul Deichmann, who assumed command over the I Air Corps early in November 1943, describes the situation in the Crimea as he undertook his new duties:

On the Crimean Peninsula the corps [I Air Corps] had a few dive-bomber units and a few fighter and reconnaissance squadrons. It also controlled a few Rumanian air units, including a dive-bomber group. Air Command Black Sea, under Lieutenant Colonel Schalke, had only a few naval and air-sea rescue squadrons.

Airfields were available for bombers as well as supplies, the latter being at Sarabuz airfield. In addition, an air base area command (Lieutenant Colonel Wolfien) was at the disposal of the corps in the Crimea.

The corps headquarters staff was then at Nikolayev on the mainland. Initially it was under an acting chief of staff, Lieutenant Colonel Schult (GSC), who was later replaced by a permanent chief of staff, Lt. Col, Krafft von Delmensingen (GSC). This staff was responsible for the conduct of operations in support of the Sixth Army on the southern flank of the Eastern Front, insofar as this support was necessary and available bomber forces were not required in the Crimea. 
The bomber units assigned to the corps from time to time were stationed at the Nikolayev airfield. There was also a fighter command headquarters in Nikolayev under Col. Dietrich Hrabask, which controlled the German fighter group operating out of Bagarovo in the Crimea (under Maj. Gerhard Barkhorn*), and a fighter force stationed at Nikolayev-West. Besides this, there were a few reconnaissance squadrons assigned to the corps on the mainland which supported Army Group "A" or the Sixth Army.

Upon examining the situation on the mainland, I discovered that no preparations had been made for air operations in the southern area of the theater if the German lines were retired and Nikolayev lost. I therefore immediately requested Fourth $\mathrm{Air}$ Fleet Headquarters to develop airfields in specified areas for light air units and to build up the necessary logistical stocks. The designated areas were in the rear.

I then assumed command in the Crimea. The situation there was very disturbing. German and Soviet forces were face to face at three narrow entrances to the peninsula, and the Russians had succeeded some time before in establishing a bridgehead on the Kerch Peninsula. Other German forces were in positions along the shores of the Sivash Sea in the northern Crimea, with only a narrow and shallow channel between them and the Soviet forces on the opposite shore. The Russians were constructing underwater causeways, with the intention of moving tanks across the water if necessary. In the October Revolution of 1917 the Communists under Stalin captured the Crimea from the White Russian forces in an attack across the Sivash Sea, and it was therefore assumed that preparations were being made here under Stalin. 26

Besides the Sivash front, German forces clung to the narrow front across the Perekop Peninsula and the Kerch Peninsula, Because the

*Editor's Note: Germany's second highest fighter ace, with 301 . victories. He flew 1,104 combat missions during the war, on both Eastern and Western Fronts. 
Crimea was virtually cut off from the mainland and all logistical connections, supplies and replacements had to be routed thro ugh Odessa or Nikolayev for shipment by sea or air to the Seventeenth Army area. There were no substantial numbers of replacements or stocks of supplies available on the peninsula.

If the Russians breached any one of the three main defense lines, they could pour into the plains on the peninsula where it would be impossible to halt them because of a lack of reserves, and the other fronts would then automatically collapse. With this possibility in mind the Seventeenth Army planned for a very speedy withdrawal of its forces from the north and northwest toward the south and southeast through Simferopol to Sevastopol. Antitank defense lines were to be established to halt Soviet tanks which might outrun the general enemy advance. Actually, the only place in which such a line could be well established was along the eastern boundary of the Sevastopol fortress.

In view of these circumstances, General Deichmann ordered the air base area command to use everything available to develop a number of small airfields in the Sevastopol area for light air units and a few landing strips for liaison and transport planes. The larger field at Khersones was to be prepared for use by bombers, and all Luftwaffe stores, such as fuel, ammunition, and the like, were to be moved back within the Sevastopol defense perimeter.

In a study, copies of which were handed to the various unit commanders, Deichmann set up the withdrawal schedules to be followed in case any of the three army fronts should be breached. The study provided for a retirement by phase lines or an all-out withdrawal in a single movement according to the situation. The I Air Corps' mission in the Crimea was to: (1) interdict the movement of supplies across the Straits of Kerch to Soviet forces in position on the western shore; (2) attack Soviet shelters, billets, and artillery concentrations in the Kerch beachhead; (3) interfere with the construction of causeways across the Sivash Sea, insofar as it was possible to interfere with underwater structures; (4) protect the German front at the Kerch beachhead against Soviet air attacks, this being the area of main emphasis for enemy air action; (5) maintain day and night air reconnaissance in the areas around the Crimea, keep under observation the Soviet Black Sea Fleet in the ports of Sukhumi, Poti, and Batum, and conduct strategic reconnaissance in the Soviet rear areas north of the Crimea; and (6) protect German convoy traffic from Konstanza, Odessa, and Nikolayev to the Crimea against Soviet air attacks. 
In order to execute the first three parts of the above mission, one or two groups at a time of the bomber wing at Nikolayev were transferred in rotation to Sarabuz to support the German and Rumanian dive-bomber group there. Since the number of trichloroethylene bombs stored at Sarabuz was far in excess of local requirements, and because it was difficult to evacuate them, General Deichmann obtained approval to use them in these missions. They had a tremendous blast effect and were used primarily in attacks against shelters and artillery positions in the city of Kerch.

Attacks with light fragmentation-type bombs were made upon Soviet loading and landing points in order to interrupt enemy traffic (mostly night traffic) across the Straits of Kerch. German aircraft also strafed Soviet shipping, most of which consisted of small craft of one type or another. Owing to the murky character of the water in the Sivash Sea (known also ав the Putrid Sea), nothing could be determined concerning the effectiveness of attacks against the causeways being constructed by Soviet forces. Since the top surfaces of these causeways were below the water's level, the Luftwaffe concentrated upon attempting to prevent the construction of these crossings by making night attacks with Iight fragmentation bombs upon the working parties.

Pursuant to orders from the Commander in Chief of the Luftwaffe, the IV Air Corps (on the mainland behind the Eighth Army) was withdrawn in December for training as a strategic bombing corps. 27 The I Aix Corps then had to extend its operational area from the Crimea to the mainland, for which tasks it was to receive a number of light units from the IV Air Corps. General Deichmann recalls the critical nature of the Eighth Army front at this time:

Since fierce fighting had developed in the Eighth Army sector east of Kirovograd, where Soviet tanks had achieved a breakthrough, and since no combat activity of any appreciable size was in progress at the time in the Crimean Peninsula, I decided to take personal charge of air operations in the threatened area. Placing Colonel Bauer in charge on the peninsula as Commanding Officer, Air Command Crimea, I proceeded by air to the IV Air Carps command post (General Meister) at Kirovograd, where I landed during a heavy snowstorm.

At the Kirovograd airfield I found more than 100 aircraft, including a large number of twin-engine bombers, which had been unable to take off because of bad weather. 


\section{THIS PAGE DECLASSIFIED IAW E012958}

Soviet tanks had meanwhile approached to within a few miles of the field and had then unexpectedly come to a halt, probably because of fuel shortages.

A brief spell of better weather then followed which made it possible to evacuate the airfield, leaving behind only a few unserviceable aircraft which were destroyed. While the evacuation was in progress, a formation of Soviet IL-2 planes attacked the airfield, setting one of the large hangars on fire with bombs. I thereupon gave the order to demolish the airfield.

I moved, together with the headquarters staff of the IV Air Corps, to Novo Ukrainka, where my own staff had in the meantime arrived to facilitate the transfer of command, 28

Because of a lack of space, certain headquarters elements could not transfer to Deichmann's new command post. These included the supply, administration, and medical sections of his staff. Therefore, from that time on the command staff remained separated into first and second echelons.

The few bomber units remaining to the I Air Corps were based on an airfield to the west of Kirovograd, while the light units operated from airfields north of Novo Ukrainka, on which the snow had been rolled flat. Units of the 2nd Dive-Bomber Wing (probably the 2nd and $3 r d$ groups) were at Zlynka, while fighter and ground-attack aircraft were based at Malaya Viska, 6 miles farther to the north. 29

On the Crimean Peninsula, completely isolated from German forces on the mainland, stood the Seventeenth Army, and with it the 9th Flak Division and the weak forces of Air Command Crimea. As the year 1943 drew to a close they awaited the Soviet offensive which was sure to come, an offensive aiming at the recapture of the entire peninsula. 